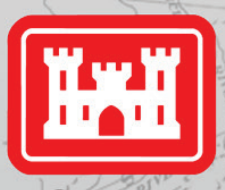

US Army Corps of Engineers ${ }_{\circledast}$

\title{
Mississippi River and Tributaries Flowline Assessment: Atchafalaya River Sedimentation Model Report
}

MRG\&P Report No. 24; Volume 5 • December 2018

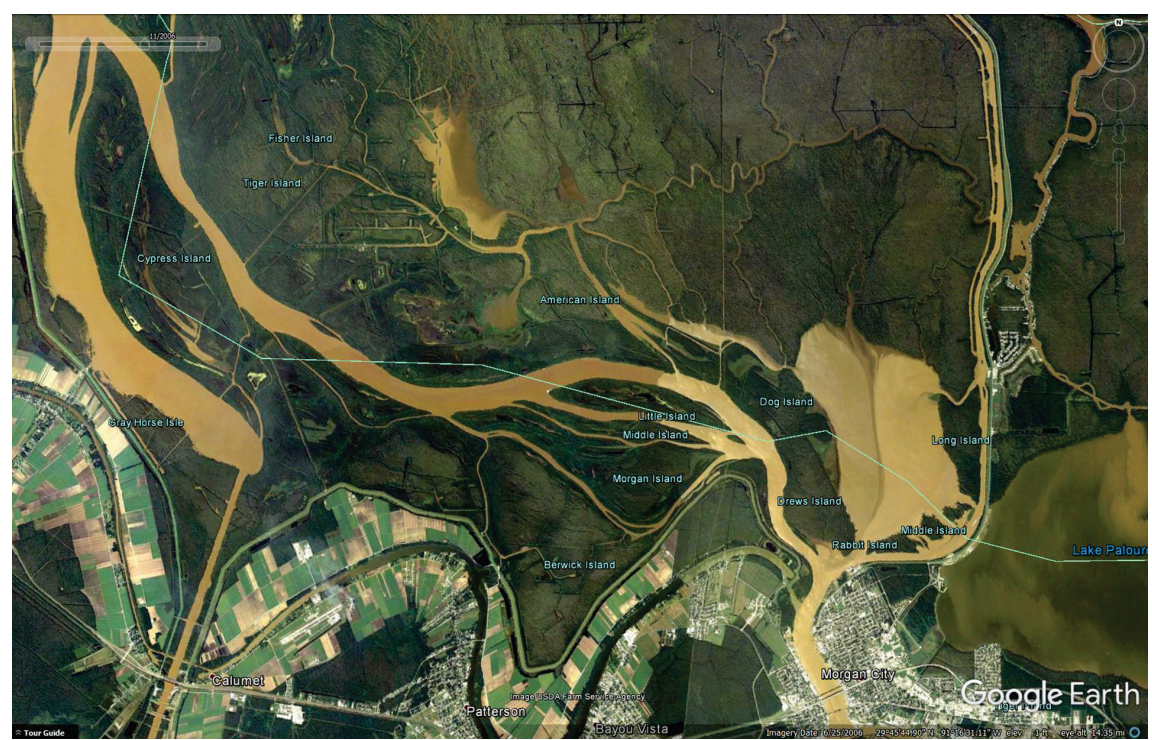

\section{MRG\&P}

Mississippi River Geomorphology \& Potamology Program 


\section{Mississippi River and Tributaries Flowline Assessment: Atchafalaya River Sedimentation Model Report}

James W. Lewis

Coastal and Hydraulics Laboratory

U.S. Army Engineer Research and Development Center

3909 Halls Ferry Road

Vicksburg, MS 39180-6199

Ronald R. Copeland

U.S. Army Engineer Mississippi Valley Division

1400 Walnut St

PO Box 80

Vicksburg, MS 39180-0080

Report 5 of a series

Approved for public release; distribution is unlimited.

Prepared for U.S. Army Corps of Engineers, Mississippi Valley Division Mississippi River Geomorphology \& Potamology Program 1400 Walnut Street

Vicksburg, MS 39180

Under Project Number 449963, “Mississippi River and Tributaries Flowline Assessment" 


\section{Abstract}

A HEC-6T numerical sedimentation model study was conducted to determine the effects of long-term sedimentation processes on the Project Design Flood (PDF) flowline for the Atchafalaya River. The upstream extent of the model was the confluence of the Red River and the Old River Control Complex outflow channel, approximately 8.5 miles upstream of Simmesport, LA. There were two downstream ends of the model; each extended to the Gulf of Mexico, one for the Wax Lake Outlet and one for the Lower Atchafalaya River. The model was built from a previous study performed in 2010 using 1997 geometry. The calibration time period was 1997 to 2010, and bed elevations were compared with a 2010 bathymetric survey. The model was validated by simulating the years 1997 through 2016. Then the model simulated 50 years, from 2017 to 2066. Average bed changes were provided to the HEC-RAS model. The model incorporated the Morganza Control Structure flows, dredging, subsidence, and sea level rise. Model results showed that the Wax Lake Outlet is capturing an increasing amount of flow from the Lower Atchafalaya River, and the PDF scours the channel bed elevations during the rising limb of the hydrograph, especially near Morgan City.

DISCLAIMER: The contents of this report are not to be used for advertising, publication, or promotional purposes. Citation of trade names does not constitute an official endorsement or approval of the use of such commercial products. All product names and trademarks cited are the property of their respective owners. The findings of this report are not to be construed as an official Department of the Army position unless so designated by other authorized documents. 


\section{Contents}

Abstract................................................................................................................ ii

Contents...................................................................................................................................... ifi

Figures and Tables.............................................................................................................

Preface .......................................................................................................................... ix

Unit Conversion Factors.................................................................................................... x

1 Introduction ............................................................................................................... 1

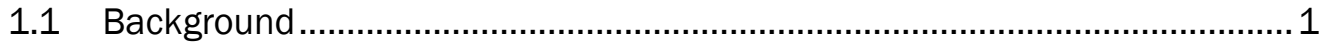

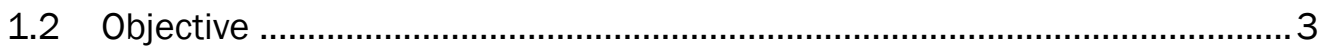

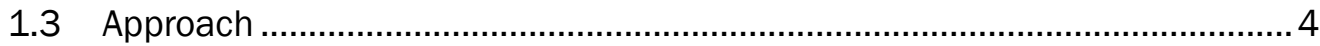

2 Model validation..................................................................................................... 5

2.1 Data compilation ........................................................................... 5

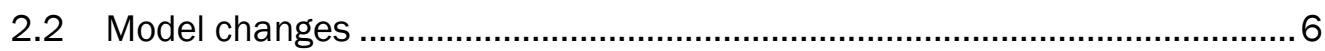

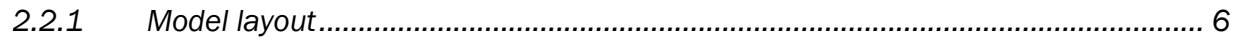

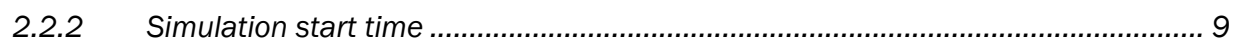

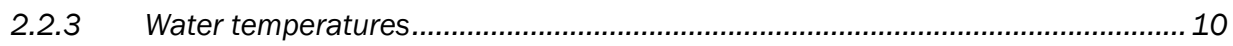

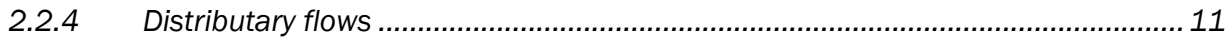

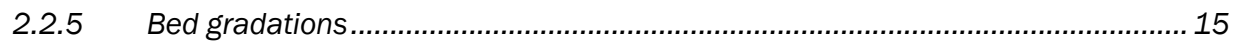

2.2.6 Sediment diversion coefficients ................................................................... 16

2.2.7 Cross-section adjustment factors ................................................................ 16

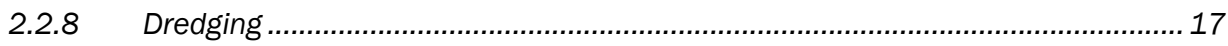

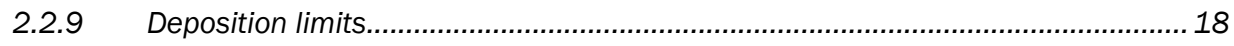

2.3 Boundary conditions ..................................................................... 19

2.3.1 Inflow at Simmesport, LA.............................................................................. 19

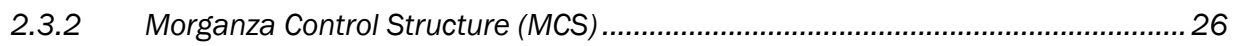

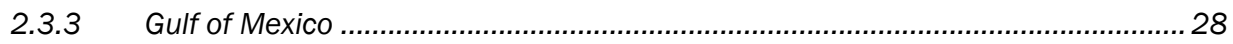

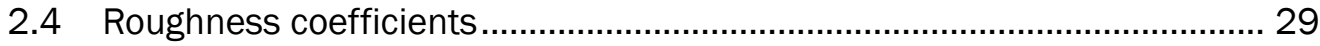

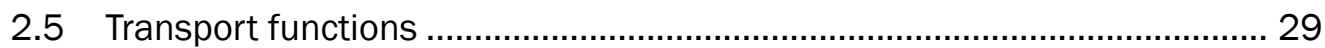

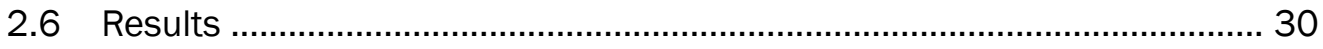

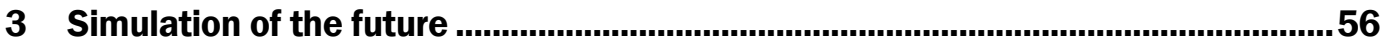

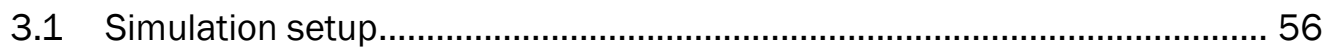

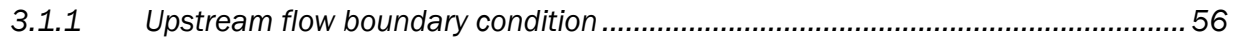

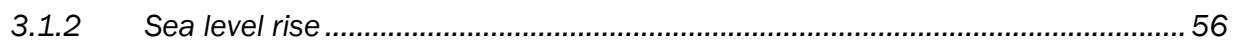

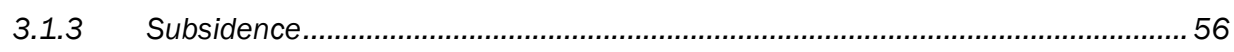

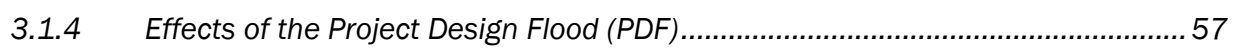

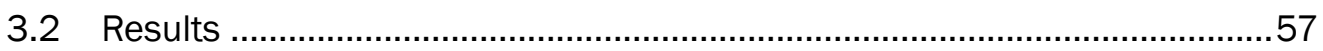

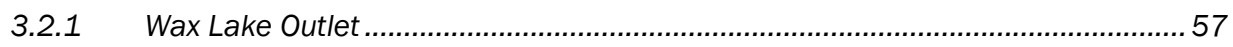

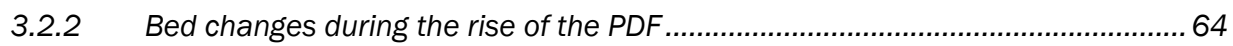




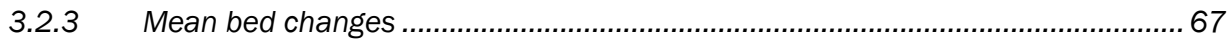

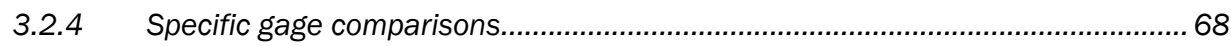

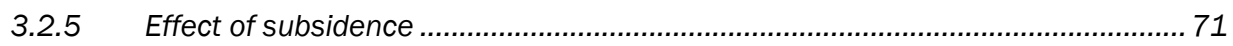

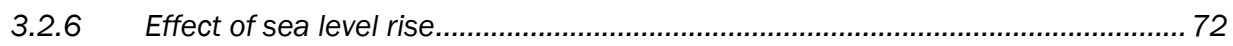

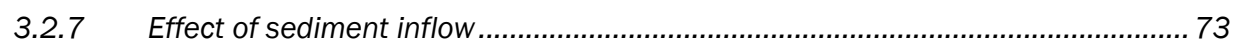

3.2.8 Effect of Wax Lake Outlet sediment diversion coefficient ..................................... 75

3.2.9 Effect of water temperature .............................................................................. 77

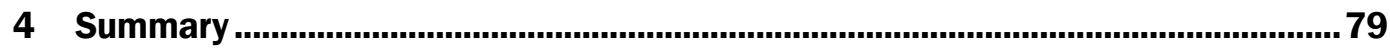

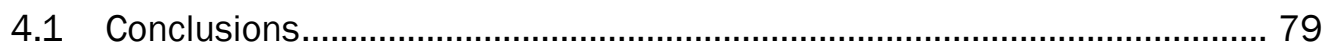

4.2 Connection to hydraulic modeling …................................................... 79

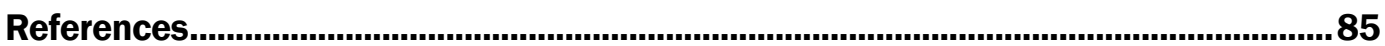




\section{Figures and Tables}

\section{Figures}

Figure 1. Schematic of the HEC-6T model segment numbers. ......................................... 7

Figure 2. Approximate locations of removed loop segments.............................................. 9

Figure 3. Monthly water temperatures used in the HEC-6T model. .................................... 10

Figure 4. Inflow and outflow locations in segments 3, 4, and 5 of the HEC-6T model.

Figure 5. Inflow and outflow locations in segments 1 and 2 of the HEC-6T model........... 13

Figure 6. Dredge site locations within the HEC-6T model. .............................................. 18

Figure 7. Example cross section -106.7 from Segment 1 showing lack of deposition in the floodplain............................................................................................... 19

Figure 8. Sand concentration at Simmesport, LA......................................................... 22

Figure 9. Proportions of coarse sediment sizes at Simmesport, LA (CS: coarse sand; MS: medium sand; FS: fine sand; VFS: very fine sand). ........................................... 23

Figure 10. Total sediment concentrations at Simmesport, LA.............................................. 24

Figure 11. Fine sediment proportions for Simmesport, LA (CS: coarse sand; MS: medium sand; FS: fine sand; VFS: very fine sand; CSILT: coarse silt; MSILT: medium silt; FSILT: fine silt; and VFSLT: very fine silt).

Figure 12. Observed and simulated flows through (a) Morgan City and (b) Calumet during the 2011 flood.

Figure 13. Comparison of computed sand concentrations using the a) Laursen-

Copeland and b) Toffaleti transport functions.

Figure 14. Simulated and observed water surfaces for the Avoca Island Cutoff south of Morgan City, LA.

Figure 15. Simulated and observed water surfaces for the Lower Atchafalaya

River at Morgan City, LA.

Figure 16. Simulated and observed discharges for the Lower Atchafalaya River at Morgan City, LA.

Figure 17. Simulated and observed water surfaces for the Wax Lake Outlet at Calumet, LA.

Figure 18. Simulated and observed discharges for the Wax Lake Outlet at Calumet, LA.

Figure 19. Simulated and observed water surfaces near Myette Point near Charenton, LA.

Figure 20. Simulated and observed water surfaces for the Atchafalaya River near Butte La Rose, LA.

Figure 21. Simulated and observed water surfaces for the Atchafalaya River at Melville, LA.

Figure 22. Simulated and observed water surfaces for the Atchafalaya River at Simmesport, LA. 
Figure 23. Simulated and observed discharges for the Atchafalaya River at Simmesport. LA.

Figure 24. Coarse sediment concentrations for the Lower Atchafalaya River at Morgan City, LA, for 1997-2016.

Figure 25. Total sediment concentrations for the Lower Atchafalaya River at Morgan City, LA, for 1997-2016.

Figure 26. Coarse sediment concentrations for the Wax Lake Outlet at Calumet, LA, for 1997-2016.

Figure 27. Total sediment concentrations for the Wax Lake Outlet at Calumet, LA, for 1997-2016.

Figure 28. Coarse sediment concentrations for the Atchafalaya River at Mellville, LA, for 1997-2016.

Figure 29. Total sediment concentrations for the Atchafalaya River at Mellville, LA, for 1997-2016.

Figure 30. Coarse sediment concentrations for the Atchafalaya River at

Simmesport, LA, for 1997-2016.

Figure 31. Total sediment concentrations for the Atchafalaya River at Simmesport, LA, for 1997-2016,

Figure 32. Comparison of computed and observed concentrations at Simmesport, LA. 51

Figure 33. Comparison of computed and observed concentrations at Melville, LA.......... 51

Figure 34. Comparison of computed and observed concentrations at Calumet, LA.

Figure 35. Comparison of computed and observed concentrations at Morgan

City, LA. 52

Figure 36. Comparison of bed elevations for cross section -4.77 in Segment 6.............. 53

Figure 37. Comparison of bed elevations for cross section -35.7 in Segment 6. ...............54

Figure 38. Comparison of bed elevations for cross section -66.1 in Segment 4.............. 54

Figure 39. Comparison of bed elevations for cross section -89.7 in Segment 3............... 55

Figure 40. Comparison of bed elevations for cross section -104.0 in Segment 1. ............55

Figure 41. Changes in discharge percentages at Calumet and Morgan City. (Calculated between 1997 and 2066 for a bankfull discharge and a flood discharge. Discharge magnitudes are from Simmesport.)

Figure 42. Changes in discharge percentages at Calumet and Morgan City with no limitation on bed erosion. (Calculated between 1997 and 2066 for a bankfull discharge and a flood discharge. Discharge magnitudes are from Simmesport.) ..

Figure 43. Calculated average bed change 2010-2066 showing the effect of limiting erosion potential in the Wax Lake Outlet.....

Figure 44. Effects of the bed changes during the rise of the PDF event on the peak water surfaces.

Figure 45. PDF water surface elevations of the Atchafalaya River main channel and Wax Lake Outlet.

Figure 46. Calculated peak water surface profiles for the PDF and the 2011 flood. 
Figure 47. Calculated and measured specific gage at Simmesport (RM -4.34)................69

Figure 48. Calculated and measured specific gage at Melville (RM -29.6)......................69

Figure 49. Calculated and measured specific gage at Calumet (RM -111.2).................... 70

Figure 50. Calculated and measured specific gage at Morgan City (RM -121.2).............. 71

Figure 51. Water surface elevations for the PDF in 2066 with and without subsidence.

Figure 52. Water surface elevations for the PDF in 2066 with the three SLR curves (only segments 1, 3, 4, and 6 are shown for clarity).

Figure 53. Sand concentration at Melville, 1995 to 2017.

Figure 54. Impact of a sediment inflow adjustment in specific gage at

Simmesport.

Figure 55. Effects of sediment diversion coefficient on sand concentrations at Calumet (SD: sediment diversion coefficient into the Wax Lake Outlet).

Figure 56. Effects of sediment diversion coefficient on total sediment concentrations at Calumet (SD: sediment diversion coefficient into the Wax Lake Outlet). .

Figure 57. Effects of sediment diversion coefficient on sand concentrations at Morgan City (SD: sediment diversion coefficient into the Wax Lake Outlet).

Figure 58. Effects of sediment diversion coefficient on total sediment concentrations at Morgan City (SD: sediment diversion coefficient into the Wax Lake Outlet)

Figure 59. Effects of sediment diversion coefficient on bed elevations for cross section -104.0 in Segment 1.

Figure 60. Water surface elevations for the PDF in 2066 with constant water temperature and with monthly average water temperature (only segments 1,3 , 4 , and 6 are shown for clarity).

Figure 61. Difference in calculated PDF peak water surface elevation after 56 years. (The difference is determined by subtracting the water surface elevation calculated using the actual geometry and the 2010-2066 hydrograph from the water surface elevation calculated using the "adjusted" channel bed geometry, where "adjusted" is based on Table 7.).

Figure 62. Difference in calculated PDF peak water surface elevation due to the rise of the PDF hydrograph. (The difference is determined by subtracting the water surface elevations calculated using the actual geometry and the PDF hydrograph from the water surface elevation calculated using the "adjusted" channel bed geometry and an instantaneous PDF peak discharge, where "adjusted" is based on Table 7.)

\section{Tables}

Table 1. List of reports included in the overall project.......................................................... 3

Table 2. Local inflow and outflow locations within the HEC-6T model (see Figure 4 and Figure 5).

Table 3. Sediment inflow boundary condition used in the HEC-6T model. 
Table 4. Metrics for hydraulic differences between computed and observed values (RMSE measures the error between the computed and observed values. NSE measures the predictive power of the model. Blank cells indicate that observations are not available.).

Table 5. Metrics for sediment differences between computed and observed values. (RMSE measures the error between the computed and observed values. NSE measures the predictive power of the model.) 32

Table 6. Data used for inflow boundary condition...............................................................56

Table 7. Average bed change results by reach. .80 


\section{Preface}

This assessment was conducted for the U.S. Army Corps of Engineers (USACE), Mississippi Valley Division (MVD), under Project Number 449963, "Mississippi River and Tributaries Flowline Assessment." The report is published through the Mississippi River Geomorphology and Potamology (MRG\&P) Program. The MRG\&P Program is part of the Mississippi River and Tributaries Program and is managed by the USACE MVD and Districts. The MVD Commander was MG Richard G. Kaiser. The MVD Director of Programs was Mr. Jim Bodron. The Vicksburg District (MVK) Commander was COL Michael C. Derosier. The Memphis District (MVM) Commander was COL Michael A. Ellicott. The New Orleans District (MVN) Commander was COL Michael N. Clancy.

The work was performed by the U.S. Army Engineer Research and Development Center, Coastal and Hydraulics Laboratory - River Engineering Branch and the Mississippi Valley Division.

COL Ivan P. Beckman was the Commander of ERDC, and Dr. David W. Pittman was the Director. 


\section{Unit Conversion Factors}

\begin{tabular}{|l|c|l|}
\hline Multiply & By & To Obtain \\
\hline cubic feet & 0.02831685 & cubic meters \\
\hline degrees Fahrenheit & $(\mathrm{F}-32) / 1.8$ & degrees Celsius \\
\hline feet & 0.3048 & meters \\
\hline miles (U.S. statute) & $1,609.347$ & meters \\
\hline square feet & 0.09290304 & square meters \\
\hline tons (force) & $8,896.443$ & newtons \\
\hline
\end{tabular}




\section{Introduction}

\subsection{Background}

In 2011, the Mississippi River and Tributaries System (MR\&T) contained one of the largest floods on record in the Mississippi River Basin without a single loss of life. However, water levels in many locations came very close to overtopping the existing levees. Following the 2011 flood, the Mississippi Valley Division began to assess the MR\&T System to determine its adequacy in handling the Project Design Flood (PDF). The assessment included a re-evaluation of very high hydrologic flow sequences with a reasonable chance of occurring. An unsteady onedimensional (1D) fixed-bed hydraulic model was used to assess the water surface elevations that result from the PDF flows. In addition to understanding the expected water surface elevations from a PDF occurring in the near future, the assessment also estimated how channel changes over the next 50 years will impact the water surface elevations expected during the PDF if it were to occur 50 years from now. This report summarizes a simulation of sedimentation dynamics and channel changes for the Atchafalaya River over the next 50 years. These channel changes will impact the expected water surface elevations during the PDF both currently and in the future.

The MR\&T System contains several water management strategies that were developed to pass the high flows that could occur during the PDF. These strategies include employment of backwater areas, floodways, historical cutoffs, and diversions. During the PDF event, the Atchafalaya River is intended to provide a large relief to the Mississippi River, receiving one half of the peak flow passing Natchez, MS. A major diversion of water from the Mississippi River to the Atchafalaya River occurs at the Old River Control Complex (ORCC). The ORCC is presently authorized to divert 620,000 cubic feet per second (cfs). Second, the Morganza Control Structure (MCS) is authorized to pass up to 600,000 cfs through the Morganza Floodway into the Atchafalaya River during the PDF. During the PDF event, the Atchafalaya River carries 1.5 million cfs to the Gulf of Mexico. For these reasons, the Atchafalaya River is an important part of the MR\&T System strategy for passing the PDF. 
Rivers are very dynamic and can exhibit major changes over periods of time. These changes are caused by a multitude of natural and anthropogenic factors, but one of the most important drivers of river channel changes is the transport, deposition, and erosion of sediment particles within the river. If a reach of river is aggrading, that means that sediment is generally being deposited in the reach, and this aggradation can increase the water surface elevation for a particular flow. Conversely, a degrading reach of river generally experiences sediment erosion and would likely have a decreasing water surface elevation for a particular flow. In some cases, a river can take decades to reach a new equilibrium. A numerical sedimentation model, calculating sediment balances and transport through the river, provides a quantitative prediction of channel changes expected in the future.

Sedimentation changes in the Atchafalaya River were last studied by the U.S. Army Corps of Engineers in the 2010 Refined Project Flood Flow Line Report for the Atchafalaya Basin. ${ }^{1}$ The 2010 Report superseded the 1986 Design Flow Line (as reported in the January 1987 Atchafalaya Basin Project Flood Flow Line Report [USACE 1987]). The numerical sedimentation model used for the 2010 Report was provided by the New Orleans District (MVN) to the authors for this assessment. In many ways, the effort summarized in this report is intended to be an update to the 2010 Report. The changes which were required in order to adequately calibrate and validate the model to recent data are described herein.

The 2010 Report and the work of Nordin and Posada (1996) document major changes of the Atchafalaya River over the course of the last several decades due to changing inflows and decreased sediment loads. Notable changes to the system include the construction of the Old River Control Structure in 1963. The Auxiliary Structure and Hydropower Structures were added to the ORCC in 1986 and 1990, respectively. Additionally, the J. Bennett Johnston Waterway, a system of locks and dams through the Red River, was constructed from 1984 to 1994 . Measured data at the Simmesport gage show increased water inflows and decreased sediment inflows to the Atchafalaya River. The upper end of the Atchafalaya River has experienced degradation, as seen by a large drop in the specific gage

\footnotetext{
1 Mississippi River and Tributaries Atchafalaya Basin, Louisiana. DRAFT FINAL. 2010 Refined Project Flood Flow Line Hydraulic Design. October 2010, Volume 1. (Hereinafter referred to as the "2010 Report."
} 
behavior at Simmesport, LA, between the 1940s and 1970s. Since the mid1980 , the Simmesport specific gage behavior has been more stable. However, the 2010 Report observed aggradation of the lower end of the Atchafalaya River in recent decades. Atchafalaya River future channel changes are evaluated in this report.

\subsection{Objective}

This report summarizes the numerical sedimentation modeling of the Atchafalaya River. Fifty years of hydraulic and sediment conditions were simulated, through the year 2066, to determine channel changes that could impact the water surface elevations of the PDF event for the MR\&T System. The resulting channel changes were then provided to the Atchafalaya River HEC-RAS model for simulating water surfaces during the PDF event.

- Chapter 1 of this report provides background information about the Atchafalaya River.

- Chapter 2 of this report describes the calibration and validation of the numerical sedimentation model to the time period 1997 to 2016.

- Chapter 3 of this report describes the simulation of sedimentation for 50 years into the future, from 2017 through 2066.

- Chapter 4 of this report provides a summary of the Atchafalaya River sedimentation dynamics.

This report is one part of the overall MR\&T Flowline Assessment Project. Table 1 lists the series of reports associated with the overall project, with this report listed in bold font.

Table 1. List of reports included in the overall project.

\begin{tabular}{|l|l|}
\hline Report Name & Description \\
\hline Executive Summary & $\begin{array}{l}\text { The Executive Summary briefly summarizes the } \\
\text { important information from the entire project } \\
\text { assessment. }\end{array}$ \\
\hline Main Report & $\begin{array}{l}\text { The Main Report summarizes the results in each of the } \\
\text { aspects of the entire project assessment and shows } \\
\text { the combined effects of the PDF event scenarios. }\end{array}$ \\
\hline Hydrology Report & $\begin{array}{l}\text { The Hydrology Report assesses the flow of water } \\
\text { arriving to the MR\&T System during the PDF event } \\
\text { scenarios. }\end{array}$ \\
\hline
\end{tabular}




\begin{tabular}{|l|l|}
\hline Report Name & Description \\
\hline Hydraulics Report & $\begin{array}{l}\text { The Hydraulics Report assesses the water surface } \\
\text { elevations in the Mississippi and Atchafalaya rivers } \\
\text { during the PDF event scenarios. }\end{array}$ \\
\hline $\begin{array}{l}\text { Mississippi River } \\
\text { Sedimentation Report }\end{array}$ & $\begin{array}{l}\text { The Mississippi River Sedimentation Report assesses } \\
\text { how the next 50 years of sedimentation are expected to } \\
\text { change the Mississippi River channel; these changes } \\
\text { would impact the water surface elevations expected } \\
\text { during the PDF event in the future. }\end{array}$ \\
\hline $\begin{array}{l}\text { Atchafalaya River } \\
\text { Sedimentation Report }\end{array}$ & $\begin{array}{l}\text { The Atchafalaya River Sedimentation Report assesses } \\
\text { how the next 50 years of sedimentation are expected to } \\
\text { change the Atchafalaya River channel; these changes } \\
\text { would impact the water surface elevations expected } \\
\text { during the PDF event in the future. }\end{array}$ \\
\hline
\end{tabular}

\subsection{Approach}

The previous numerical sediment model provided to the authors was a HEC-6T model based on geometry from a 1997 bathymetric survey. Since the previous HEC-6T model was used in the 2010 Report, it will be referred to as the 2010 HEC-6T model within this report. The 2010 HEC6T model was revised and used in this assessment to simulate the calibration and validation time period from 1997 to 2016. A multibeam bathymetric survey and topographic survey were merged to create a new surface for the year 2010. Simulated channel changes from 1997 to 2010 were compared to the 2010 survey data. In general, the model was validated by matching the hydraulic behavior (stages and discharges), the measured sediment concentrations, and randomly selected cross-section locations of the 2010 survey data. 


\section{Model validation}

\subsection{Data compilation}

There are multiple gage locations with data used for this model. Most of the gages record only the river stage and occasional field discharge measurements. A time series of discharge data was available from the Simmesport (U.S. Geological Survey [USGS] site \# 07381490), Calumet (USGS site \#07381590 Wax Lake Outlet at Calumet, LA), and Morgan City gages (USGS site \#07381600). The 2010 HEC-6T model simulated historical conditions from 1997 to 2007. For this effort, the authors retrieved all of the available stage and discharge data for any of the gages through 2016.

All vertical elevations in this report are in North American Vertical Datum of 1988 (NAVD88). The report for the 2010 HEC-6T model (both the Main Report and the Appendix B) states that the previous model vertical elevations were all NAVD88. All other data retrieved for comparisons within this investigation used, or were converted to, NAVD88.

Sediment data were also available at some useful locations within the model domain, namely Simmesport, Mellville, Calumet, and Morgan City. The USGS provided total sediment concentrations and the percent finer than 0.0625 millimeters $(\mathrm{mm})$.

A survey data set was available for model validation, made of a 2007 lidar topographic survey and a 2010 multi-beam bathymetric survey. The topographic and bathymetric surveys were merged together to create a single surface (the horizontal coordinate system was NAD_1983_StatePlane_Louisiana_South_FIPS_1702_Feet). Some areas of the model domain did not have bathymetric data from the 2010 survey, namely the Old Atchafalaya River Channel parallel with the Whiskey Bay Pilot Channel, the Wax Lake Outlet Channel, and the Lower Atchafalaya River below the Gulf Intracoastal Waterway (GIWW). The HEC-6T model was validated to bed changes from 1997 to 2010 where 2010 data were available. 


\subsection{Model changes}

The 2010 HEC-6T model had been run with a much older version of the HEC-6T software, and it would not run successfully with recent versions. Software improvements, bug fixes, and added capabilities required that the old model be revised to run with a current version of the HEC-6T software (H6TV51425_Jo1nR_170519). One specific required change was the relabeling of the dredging sites due to software changes. In general, the approach of the authors was to review all features of the previous model but only change model features that

- resulted in a better match to available data sets, such as distributary flow data, bed gradation data, etc.

- were necessary to correct mistakes, instabilities, or inconsistencies within the model

- caused a better alignment with the new HEC-RAS hydraulic model (see Section 4.2 for more information).

The model changes are described in the following paragraphs.

\subsubsection{Model layout}

The Atchafalaya River HEC-6T model begins 8.5 miles upstream from Simmesport, LA, and continues into the Gulf of Mexico through two channels at the downstream end. The two outlets are the Wax Lake Outlet Channel, which flows past Calumet, and the Lower Atchafalaya River, which flows past Morgan City. The layout of the revised HEC-6T model used in this assessment is shown in Figure 1; the reach segment numbers are labeled by the boxes in the figure. Several changes were made to the layout from the 2010 HEC-6T model. These changes included removing some cross sections, shortening the upstream and downstream extents of the model, and eliminating some looped segments. 
Figure 1. Schematic of the HEC-6T model segment numbers.

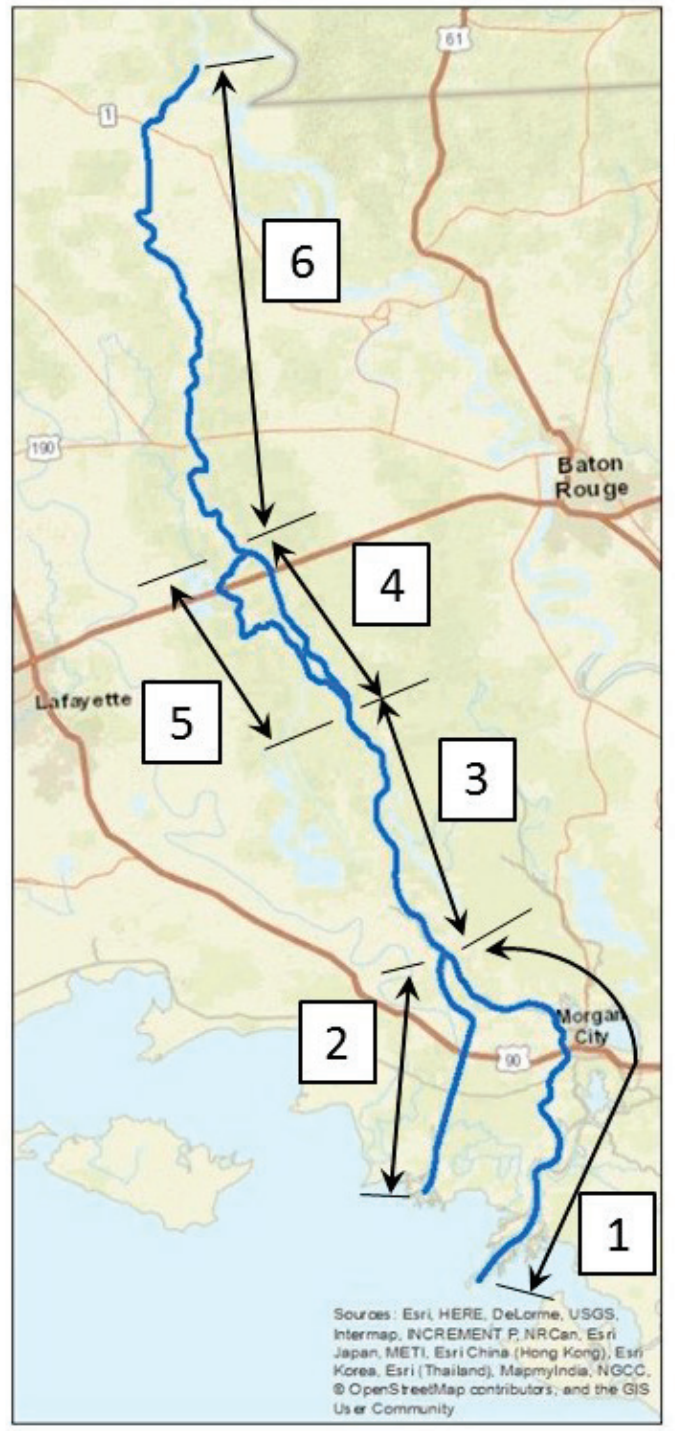

The downstream limits of the previous HEC-6T model were located far out into the Gulf of Mexico and had very wide overbanks. As flows enter into the downstream delta regions of the outlet channels, the hydraulic behavior becomes less and less 1D. Much of the flow moves laterally away from the channel. The paths of water movement are difficult to define, and the amount of water flowing within the defined channel becomes a challenge to quantify for the entire range of expected flows. For these reasons, and also to better align with the HEC-RAS model, which had downstream limits further upstream from the 2010 HEC-6T model, the downstream boundaries of the HEC-6T model were moved upstream, more so for the Wax Lake Outlet Channel (Segment 2) than the Lower 
Atchafalaya River (Segment 1). The Lower Atchafalaya River boundary was moved from River Mile (RM) -16o to RM -149. The Wax Lake Outlet boundary was moved from RM -144 to RM -125 . The boundary conditions are discussed in more detail within Section 2.3.

Near the downstream end of the model, the number of cross sections was greater than necessary for a representative HEC-6T 1D model. Since a significant amount of flow leaves the channel in the downstream area, the flow through each cross section was evaluated during early stages of this assessment. Some of the cross sections that were spaced close together (less than approximately 1,000 feet ( $\mathrm{ft}$ ) spacing) were eliminated to provide a better comparison with available information about flows in the channel. More information about the distributary flows can be found in Section 2.2.4. Nearly all of the cross sections that were removed from the previous model were located near the downstream end of the model, below the junction where the Wax Lake Outlet Channel splits from the Lower Atchafalaya River. There were more cross sections in the HEC-6T model than were in the Atchafalaya River HEC-RAS model, so the frequency of cross sections in the HEC-RAS model was also considered for consistency.

There is only one loop, or split flow around an island, simulated in the revised HEC-6T model, as seen in Figure 1. Segment 4 is the Whiskey Bay Pilot Channel, and Segment 5 is the Old Atchafalaya River Channel. Other loops existed in the 2010 HEC-6T model, which were removed. The approximate locations of the removed loop segments are shown in Figure 2. This HEC-6T model needed to simulate over 50 years of sedimentation impacts, and the individual channels of a loop within a 1D sediment transport model can easily become unstable, especially if deposition is occurring. The 2010 HEC-6T model was also used to simulate 50 years, but initial investigation of that model highlighted the instabilities within the loops. One previous loop within what is now Segment 3 was replaced by a flow leaving the channel and then returning downstream back into Segment 3. There are multiple parallel channels in the area just upstream of Morgan City, some of which were simulated by separate segments in the previous model. After reducing the HEC-6T model to just two parallel segments, it was found that this area was still unstable. Over a long simulation, one or the other of the channels filled in and caused the model to crash. The model was too sensitive and unstable, even after adjusting the sediment flow distributions around the loop, so the two parallel segments were merged into the same segment. For the cross sections that 
were in the previous parallel reaches of the loop, the right-descending channel was moved to be adjacent to the left-descending channel, and the island that had been in between them was moved to be right of the rightdescending channel. In this way, sediment was able to deposit and scour within both channels appropriately without causing odd sedimentation patterns in the island area.

Figure 2. Approximate locations of removed loop segments.

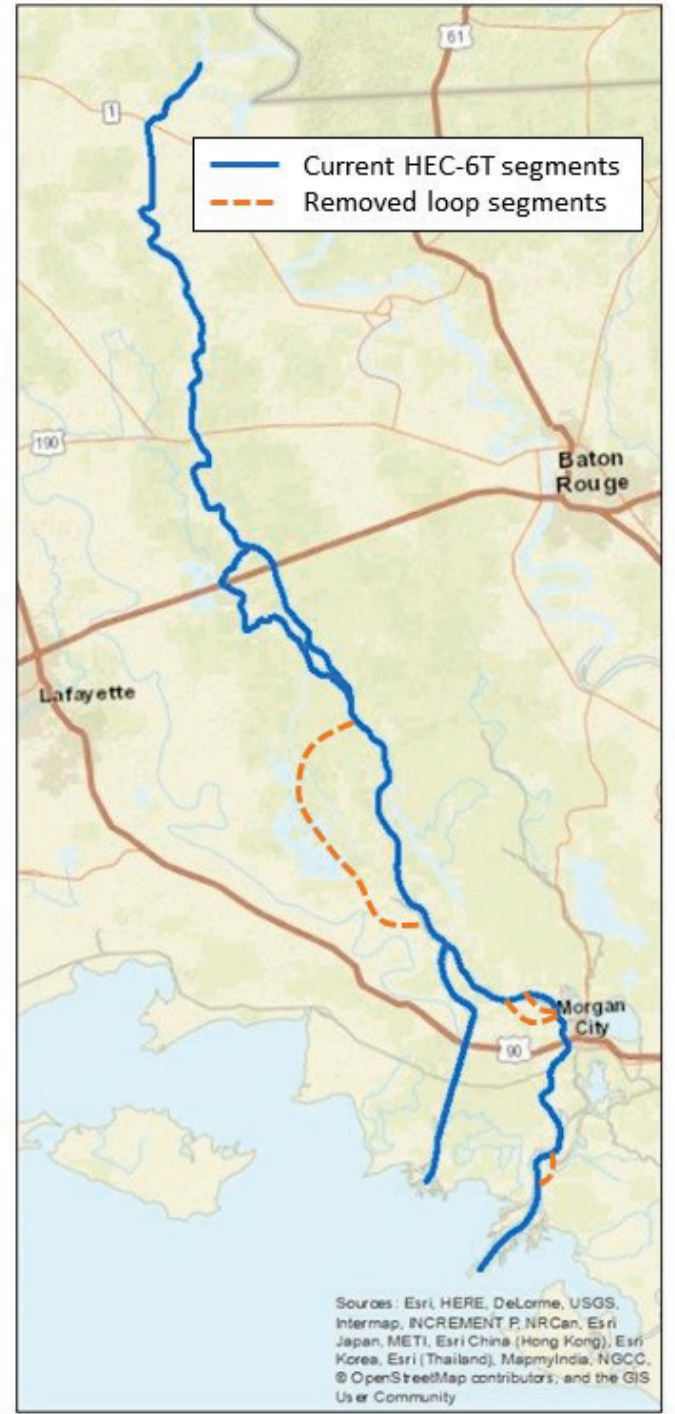

\subsubsection{Simulation start time}

The hydrograph of 1997 contained a large flow event, so the initiation of the model was important. The HEC-6T model was run with start times before and after the large flow event in the spring of 1997 to see the 
impacts, and there were significant differences in the bed elevations for the later part of the year depending on whether the 1997 event was, or was not, included. The 2010 HEC-6T model began simulating from 1 January 1997, but a closer look at the 1997 bathymetric survey documents showed that the survey data was collected as late as April of 1997. For this reason, the simulation start time was adjusted to 30 April 1997 for all runs. The computational time-step of 0.25 day was not changed from the previous model. Daily data for the boundary conditions were used by the model across four time-steps for each day. Daily time-steps could have been used with sufficient accuracy, but model simulations using the previously used 0.25 day time-steps were relatively quick.

\subsubsection{Water temperatures}

Seasonal water temperature variations were added to the model since the 2010 HEC-6T model did not include temperature changes. Water temperature can have an important influence on both sediment erosion and deposition dynamics through changes in water viscosity and density which impact shear stresses, particle settling velocities, etc. The monthly average water temperatures were computed using available historical measurements from the Simmesport, Melville, and Morgan City gages and can be seen in Figure 3. Section 3.2.9 shows a comparison between using the monthly average water temperatures and a constant water temperature.

Figure 3. Monthly water temperatures used in the HEC-6T model.

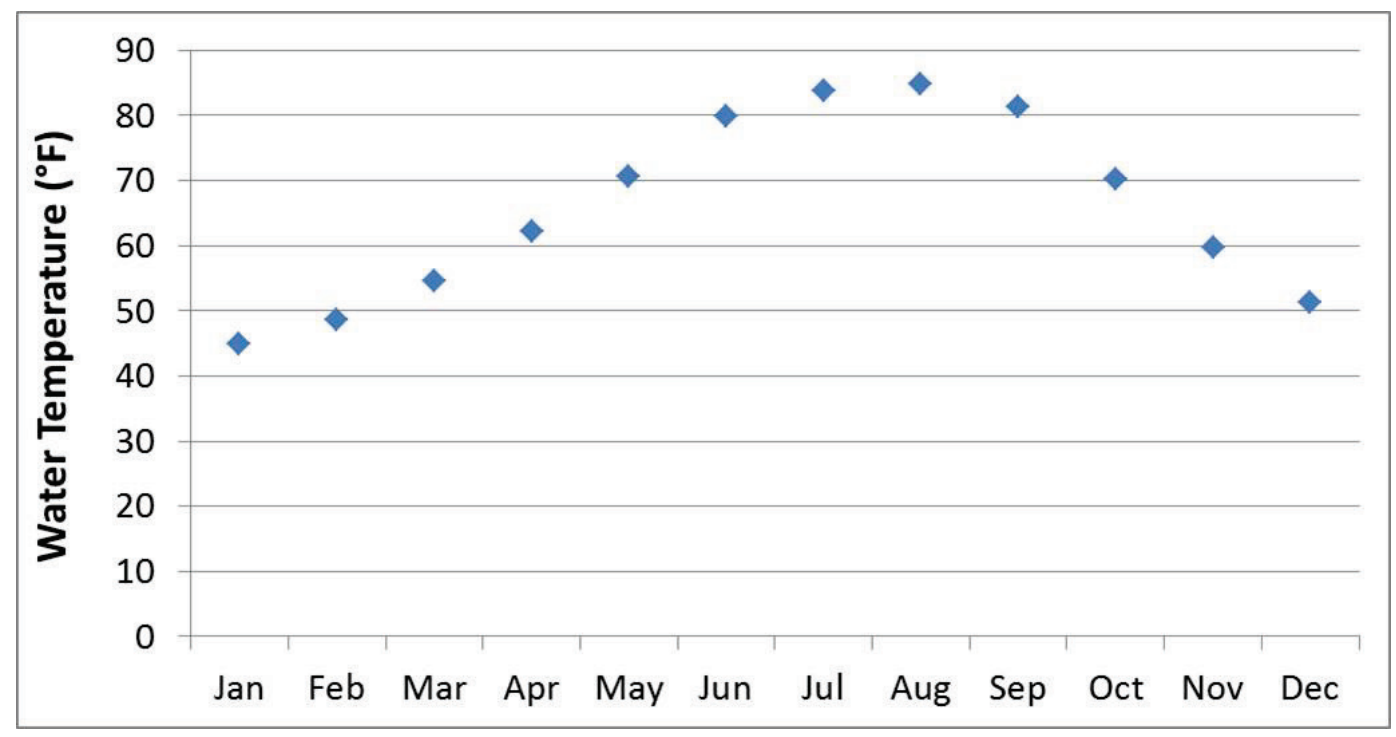




\subsubsection{Distributary flows}

The amount of flow remaining within the channel has a large influence on the sediment dynamics of a HEC-6T model, and any flows leaving or entering the channel have to be defined clearly. This is difficult with the Atchafalaya River Basin because there is a large amount of flow that is being exchanged between the river channels and the floodplain areas. The HEC-6T distributary and return flow locations are shown in Figure 4 and Figure 5. Table 2 contains a list of the distributary and return flow locations. The Atchafalaya HEC-RAS model simulated the channel reaches with 1D simulation and the floodplain areas with two-dimensional (2D) simulation, where any adjacent boundary between the 1D and 2D was calculated using a lateral weir representation. Since the HEC-RAS model simulates a higher spatial resolution of the exchange between channel and floodplain flow, many of the HEC-RAS results were used in quantifying the amount of flow within the HEC-6T model distributaries. 
Figure 4. Inflow and outflow locations in segments 3, 4, and 5 of the HEC- 6 T model.

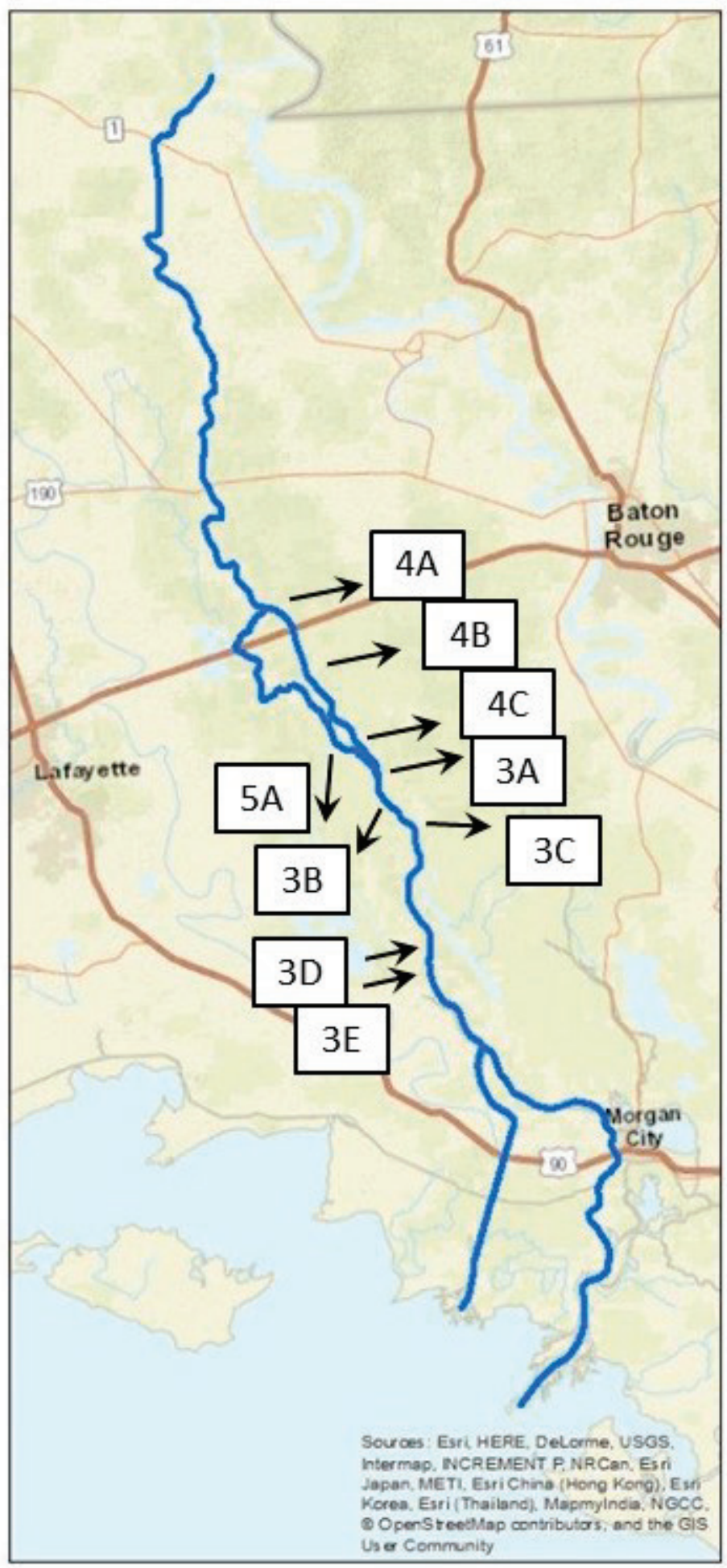


Figure 5. Inflow and outflow locations in segments 1 and 2 of the HEC-6T model.

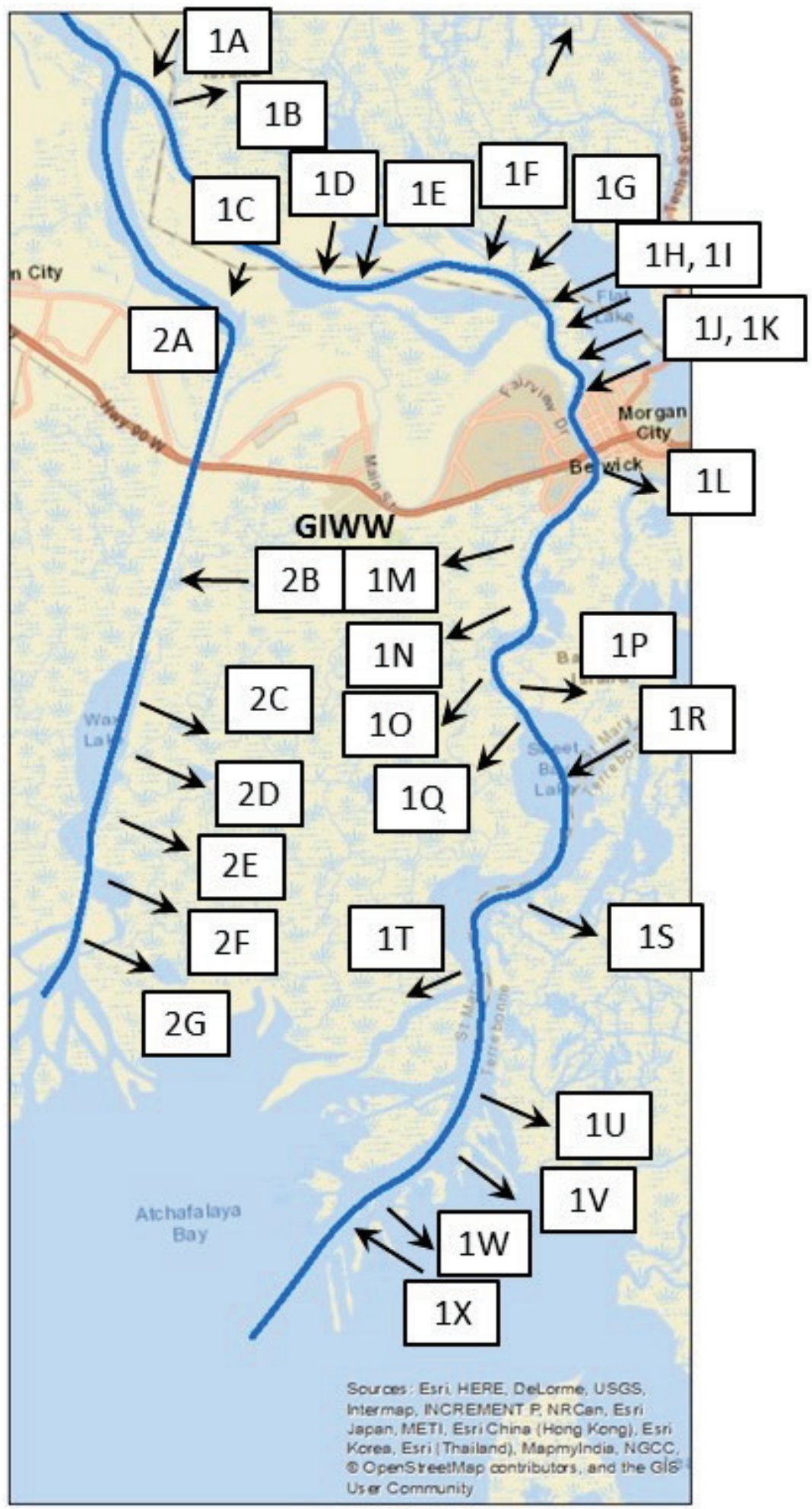


Table 2. Local inflow and outflow locations within the HEC-6T model (see Figure 4 and Figure 5).

\begin{tabular}{|c|c|c|}
\hline $\begin{array}{l}\text { Label from Figure } 4 \text { and } \\
\text { Figure } 5\end{array}$ & Type & $\begin{array}{c}\text { Distributary Cross-Section } \\
\text { (segment \#) }\end{array}$ \\
\hline $5 A$ & outflow & $-74.0(5)$ \\
\hline $4 \mathrm{~A}$ & outflow & $-56.5(4)$ \\
\hline $4 B$ & outflow & $-62.1(4)$ \\
\hline $4 C$ & outflow & $-68.75(4)$ \\
\hline $3 A$ & outflow & $-70.3(3)$ \\
\hline $3 B$ & outflow & $-78.15(3)$ \\
\hline $3 C$ & outflow & $-80.5(3)$ \\
\hline $3 D$ & return flow & -93.5 (3) \\
\hline $3 \mathrm{E}$ & return flow & $-94.4(3)$ \\
\hline $2 \mathrm{~A}$ & return flow & $-107.5(2)$ \\
\hline $2 \mathrm{~B}$ & return flow & $-114.9(2)$ \\
\hline $2 \mathrm{C}$ & outflow & $-118.6(2)$ \\
\hline $2 D$ & outflow & $-119.8(2)$ \\
\hline $2 \mathrm{E}$ & outflow & $-120.8(2)$ \\
\hline $2 \mathrm{~F}$ & outflow & $-122.7(2)$ \\
\hline $2 \mathrm{G}$ & outflow & $-123.3(2)$ \\
\hline $1 \mathrm{~A}$ & inflow & $-104.0(1)$ \\
\hline $1 \mathrm{~B}$ & outflow & $-104.8(1)$ \\
\hline $1 C$ & outflow & $-108.7(1)$ \\
\hline $1 \mathrm{D}$ & return flow & $-110.5(1)$ \\
\hline $1 \mathrm{E}$ & inflow & $-111.7(1)$ \\
\hline $1 \mathrm{~F}$ & return flow & $-116.5(1)$ \\
\hline $1 G$ & return flow & $-117.2(1)$ \\
\hline $1 \mathrm{H}$ & return flow & $-117.8(1)$ \\
\hline 11 & return flow & $-118.5(1)$ \\
\hline $1 \mathrm{~J}$ & return flow & $-118.8(1)$ \\
\hline $1 K$ & inflow & $-119.7(1)$ \\
\hline $1 \mathrm{~L}$ & outflow & $-121.4(1)$ \\
\hline $1 \mathrm{M}$ & outflow & $-124.0(1)$ \\
\hline
\end{tabular}




\begin{tabular}{|c|l|c|}
\hline $\begin{array}{c}\text { Label from Figure 4 and } \\
\text { Figure 5 }\end{array}$ & Type & $\begin{array}{c}\text { Distributary Cross-Section } \\
\text { (segment \#) }\end{array}$ \\
\hline $1 \mathrm{~N}$ & outflow & $-126.7(1)$ \\
\hline $1 \mathrm{O}$ & outflow & $-128.3(1)$ \\
\hline $1 \mathrm{P}$ & outflow & $-128.8(1)$ \\
\hline $1 \mathrm{Q}$ & outflow & $-129.6(1)$ \\
\hline $1 \mathrm{R}$ & return flow & $-130.5(1)$ \\
\hline $1 \mathrm{~S}$ & outflow & $-134.2(1)$ \\
\hline $1 \mathrm{~T}$ & outflow & $-137.5(1)$ \\
\hline $1 \mathrm{U}$ & outflow & $-140.6(1)$ \\
\hline $1 \mathrm{~V}$ & outflow & $-142.6(1)$ \\
\hline $1 \mathrm{~W}$ & outflow & $-144.4(1)$ \\
\hline $1 \mathrm{X}$ & return flow & $-146.2(1)$ \\
\hline & &
\end{tabular}

At the downstream end of the model, instead of simulating the delta region with very wide cross sections, the approach used in this assessment was to be as specific as possible about the location of the primary channel and the amount of flow within that channel. Cross-section widths were narrowed to match the HEC-RAS model. Aerial images were used to determine locations of the main distributaries. The distributary flows in the downstream end of the model were specified in the HEC-6T model using either USGS measurements taken during the flood of 1997, around 2003, or results from the HEC-RAS model.

\subsubsection{Bed gradations}

The 2010 HEC-6T model contained a bed-sorting period, where the bankfull flow of $300,000 \mathrm{cfs}$ was simulated for 173 days to adjust the bed gradations to an equilibrium state. This type of technique is commonly used in sediment transport modeling. For this report, the authors re-evaluated bed material sizes from the Nordin and Posada (1996) analysis of the Atchafalaya River. At the upstream end of the model, starting bed gradations were adjusted based on reach-averaged gradations measured. For example, the bed size measurements in RMs o through -25 were averaged together and used for the initial bed gradation. The warmup period was simulated from those initial bed sizes, and in some cases required much longer than 173 days to reach equilibrium. Also, the previous model kept both the bed gradations and the bed changes after the 
artificial warmup period. This assessment performed the bed equilibrium warmup in a separate simulation, used the resulting bed gradations, and did not use the bed elevation changes resulting from the warmup period.

\subsubsection{Sediment diversion coefficients}

Sediment diversion coefficients within the HEC-6T model specify how much of the sediment leaves when there is a split or outflow of water. These values were entered as sediment concentration fractions relative to the upstream sediment concentration. Most of the sediment diversion coefficients were kept the same as those used in the 2010 HEC-6T model. For distributaries that were added at the lower end of the model, sediment diversions coefficients were used from a previous 2005 MVN study (USACE 2005). If newly added distributaries did not have available coefficients from the 2005 Study, the flow leaving was set to carry $100 \%$ of the upstream concentration within the clay and silt size classes, $50 \%$ of the upstream concentration of very fine sands, and $0 \%$ of the coarser size classes. This was deemed reasonable because the distributaries had bed elevations significantly higher than the bed elevation of the main channel.

For the major splits within the model, the upstream junction of the Whiskey Bay Pilot Channel and the upstream junction of the Wax Lake Outlet Channel, sediment diversion coefficients were adjusted during calibration. The 2010 HEC-6T model had a small amount of coarse material (greater than $0.0625 \mathrm{~mm}$ diameter) (concentrations of $70 \%$ or less) moving into the Wax Lake Outlet channel. During this assessment, the low sediment coefficients for coarse material at that junction caused the Lower Atchafalaya River to accumulate, or deposit, too much sediment, based on comparative hydrographic surveys. To reproduce measured data, the coarse sediment coefficients (material greater than $0.0625 \mathrm{~mm}$ diameter passing into the Wax Lake Outlet relative to the concentration upstream of the junction) were increased to $100 \%$ to achieve calibration. More information about this sediment diversion coefficient is discussed in Section 3.2.8. At the Whiskey Bay junction, sediment diversion coefficients were adjusted to duplicate measured sediment accumulation in the Old Atchafalaya River between 1997 and 2010.

\subsubsection{Cross-section adjustment factors}

The HEC-6T software allows for adjustment factors that can skew the horizontal shape of the cross section by a specified amount. Upon review 
of the 2010 HEC-6T model, there were a few cross sections that were not oriented perpendicular to the flow. The ratio of perpendicular distance to the previously used distance was calculated using geographic information system techniques for each such cross section. An adjustment factor of o.87 was implemented for XS -119.2 and -118.8.

\subsubsection{Dredging}

Minor changes were needed for simulating dredging, namely to add one dredging site and to add the reintroduction of material into the channel for an existing site. Annual dredging records, provided by the MVN, showed that dredging had occurred near Calumet within the Wax Lake Outlet Channel, which was not simulated with the 2010 HEC-6T model. A dredging site was added to the model for this location, cross section -111.2. During calibration simulations, the Lower Atchafalaya River bed elevations downstream of Morgan City were lower than shown by the survey data. The dredging option assigned in the 2010 HEC-6T model permanently removed sediment dredged from the area between Berwick Bay and Morgan City. However, the typical dredging practice in this reach calls for dredged sediments to be added back into the water column downstream from the dredging site. The model dredging option was changed in the Morgan City reach to match the actual operations. Dredged materials were reintroduced into the model downstream of the dredging site at cross section -122. The approximate locations of the dredging sites in the HEC-6T model are shown in Figure 6. 
Figure 6. Dredge site locations within the HEC-6T model.

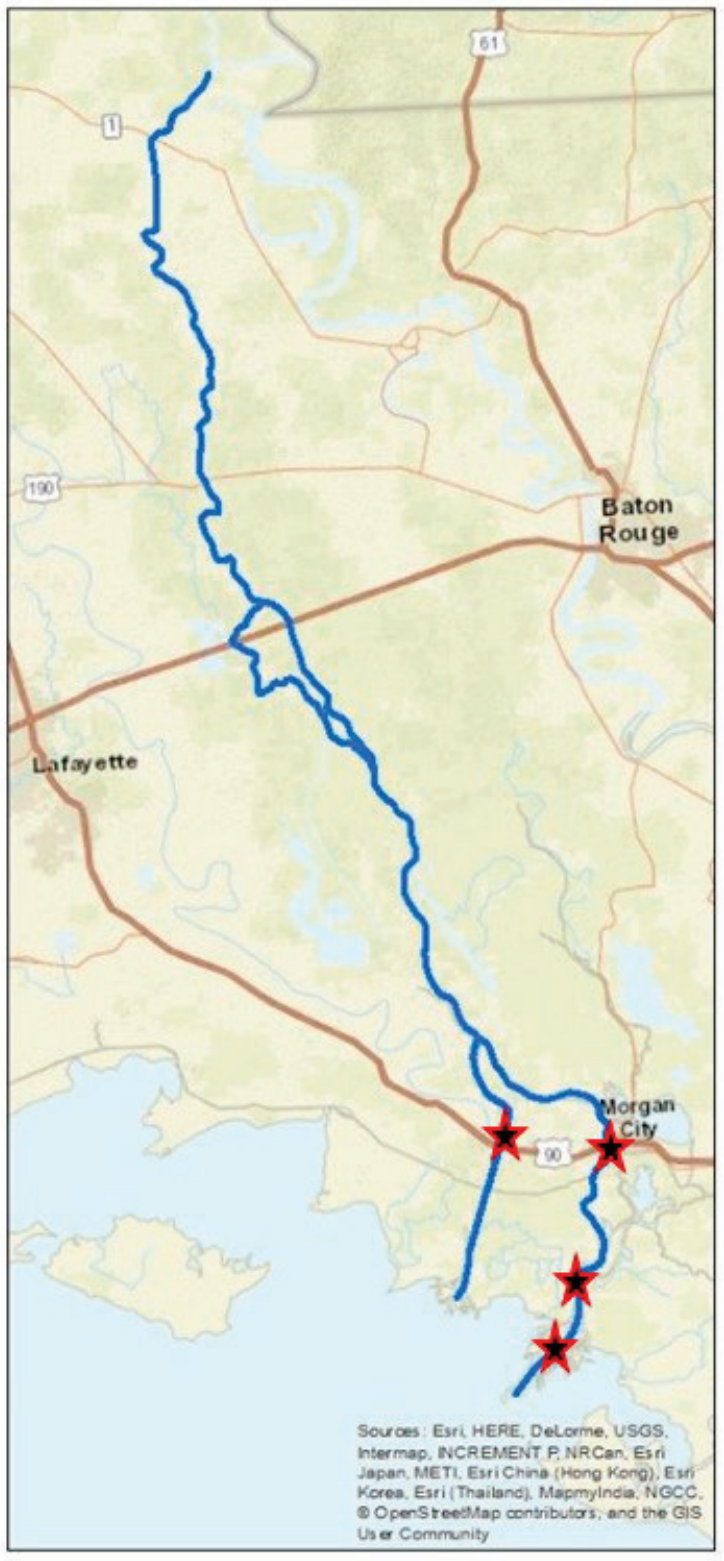

\subsubsection{Deposition limits}

The 2010 HEC-6T model simulated a large amount of deposition in the overbank floodplains of many cross sections. For example, the cross section -106.7 in Segment 1 had over $5 \mathrm{ft}$ of deposition through much of the floodplain. The survey data did not show a significant amount of deposition for the cross sections, so the deposition was restricted to only occur within the channel for many of the cross sections that experienced this issue. The resulting elevations of cross section -106.7 can be seen in 
Figure 7; the previous 2010 HEC-6T model results showed an elevation of $10 \mathrm{ft}$ for the entire right-descending floodplain, a distance of over 4,000 ft.

Figure 7. Example cross section -106.7 from Segment 1 showing lack of deposition in the floodplain.

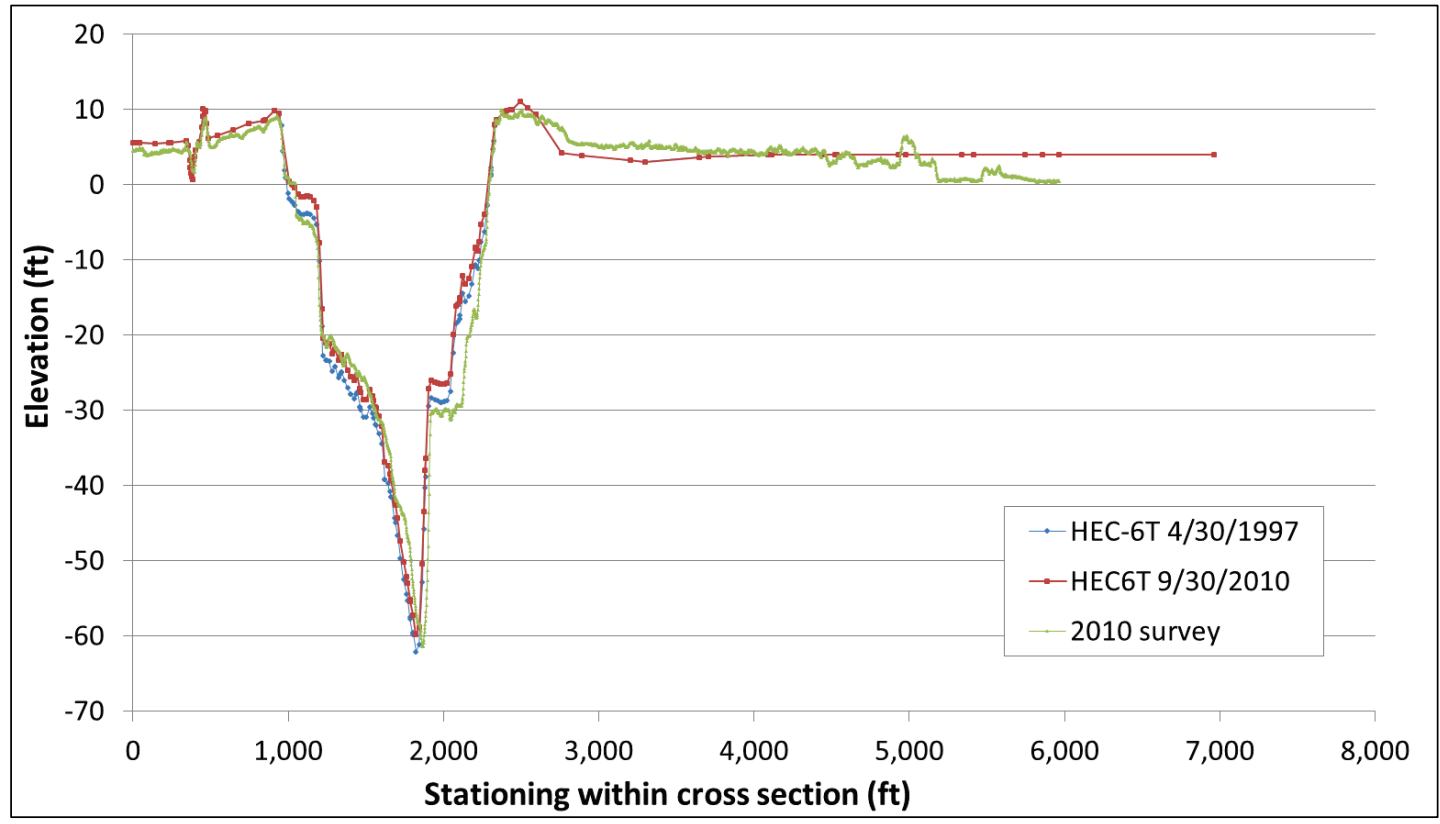

\subsection{Boundary conditions}

The typical boundary conditions required for a HEC-6T model are the flow and sediment arriving from upstream and the water surface elevation downstream. The 2010 HEC-6T model included a small part of the Red River and the ORCC outflow channel. The 2010 model's boundary conditions were based on Simmesport data with the unknown Red River flow determined by subtracting the measured ORCC outflow. Due to some discrepancies in the calculation of water and sediment inflow from the Red River, and the fact that the HEC-RAS model began at Simmesport, the upstream boundary in this study was moved closer to Simmesport. The current model begins just downstream of where the ORCC outflow channel joins the Atchafalaya River. Simmesport is only a short distance downstream from the model boundary, so the model inflows were entirely based on the Simmesport record of flows.

\subsubsection{Inflow at Simmesport, LA}

Water and sediment inflows were required boundary conditions at the upstream end of the model. Water inflow came from daily data available 
for Simmesport, LA, through River Gages (http://rivergages.com, site \#03045Q). Sediment inflow relationships were redeveloped within this project due to the availability of more recent sediment measurement data at Simmesport, LA. The steps in determining the sediment inflow curve are explained as follows:

1. The coarse sediment, or sand, concentrations were determined as a function of discharge using linear regression within a log-log scale plot of the observed data, as seen in Figure 8. Measured data prior to 1995 were not used because of the upstream changes to the Red River and ORCC, in particular the completion of the J. Bennett Johnston Waterway in 1994. Measured sediment concentrations in the decades prior to the Red River and ORCC changes are noticeably higher than the current time period. Sand concentration measurements are calculated using the measured total suspended sediment concentration and the measured percent finer than $0.0625 \mathrm{~mm}$ diameter.

A statistical correction factor was applied to the power regression equations to account for bias created by using a least-squares regression for the logarithm of concentration. This bias occurs because the power regression produces a geometric mean instead of an arithmetic mean. The geometric mean is necessarily lower than the arithmetic mean, so concentrations are underestimated using the biased equation. The bias increases with the degree of scatter about the regression. A correction factor proposed by Ferguson (1986) was used to produce an unbiased estimator for both the total measured load and the sand load. The correction factor is given in the following equation: 


$$
\begin{gathered}
\bar{C}_{i}=\hat{C}_{i} \exp \left(2.651 s^{2}\right) \\
s^{2}=\frac{\sum_{i=1}^{n}\left(\log C_{i}-\log \hat{C}_{i}\right)^{2}}{n-2}
\end{gathered}
$$

where:

$$
\begin{aligned}
\overline{C_{i}} & =\text { unbiased concentration at discharge event } i \\
\hat{C}_{i} & =\text { concentration from biased regression curve } \\
C & =\text { measured concentration } \\
n & =\text { number of measurements. }
\end{aligned}
$$

Note that the exponent is the same in the biased and unbiased equations shown in Figure 8 so that the regression curves on log-log plots are parallel.

Additionally, the data were bias-corrected so that a linear regression would be properly developed for a log-log relationship. Two linear relationships were calculated based on (1) data up through 200,000 cfs and (2) from above $200,000 \mathrm{cfs}$ through $400,000 \mathrm{cfs}$. The pattern of the data changes at approximately 200,000 cfs and then again at approximately 400,000 cfs. The sand concentration is held constant above $400,000 \mathrm{cfs}$ to avoid extrapolating too high of a concentration at high discharges. 
Figure 8. Sand concentration at Simmesport, LA.

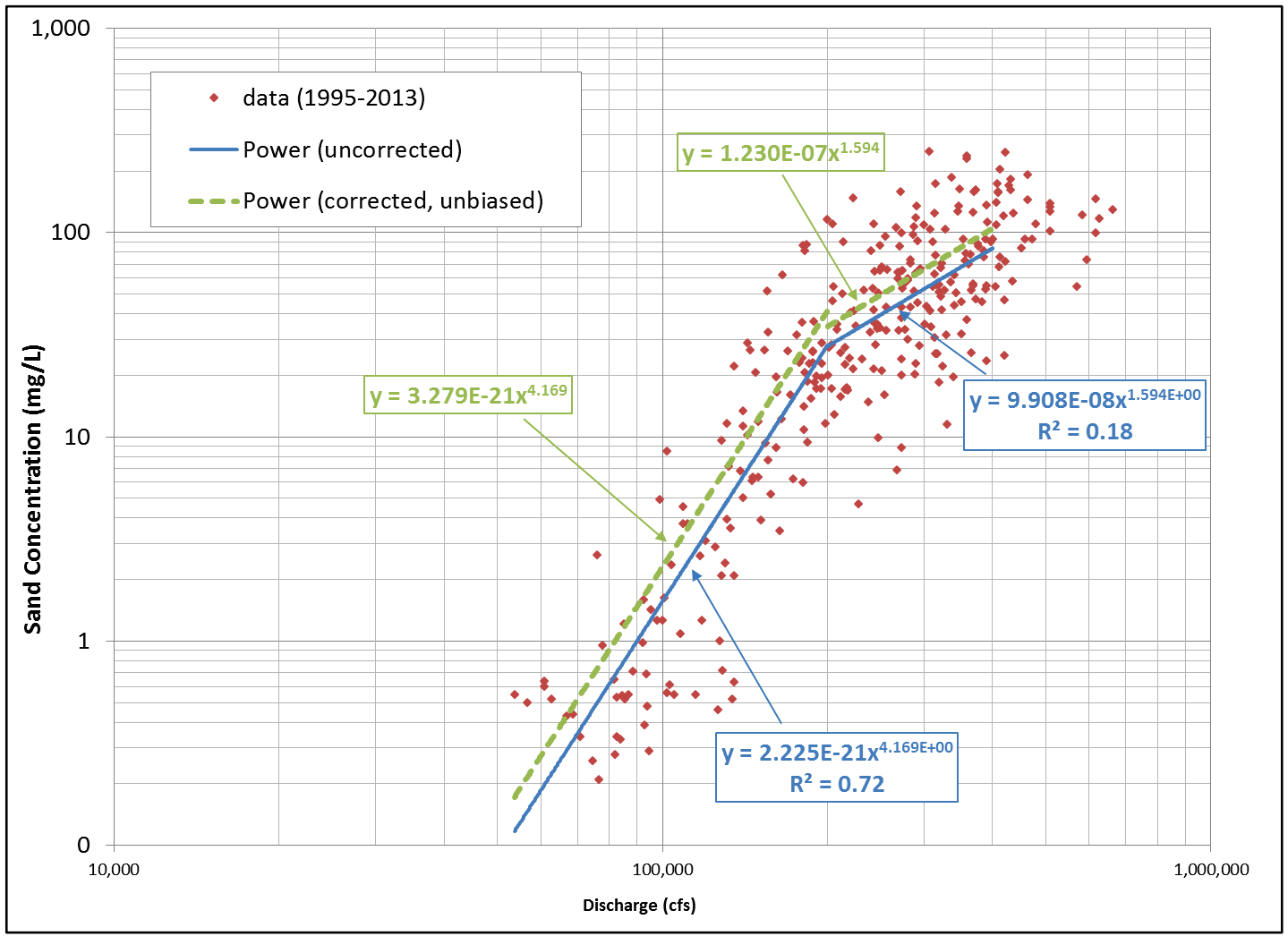

2. The sediment size gradations within the measurements were used to determine the proportions of each size class. Figure 9 shows the proportions of the coarse sediment size classes as a function of discharge. Relationships of the sediment proportions were determined within the range of discharges available, as shown in Figure 9. Proportions were held constant for discharges above 600,000 cfs. 
Figure 9. Proportions of coarse sediment sizes at Simmesport, LA (CS: coarse sand; MS: medium sand; FS: fine sand; VFS: very fine sand).

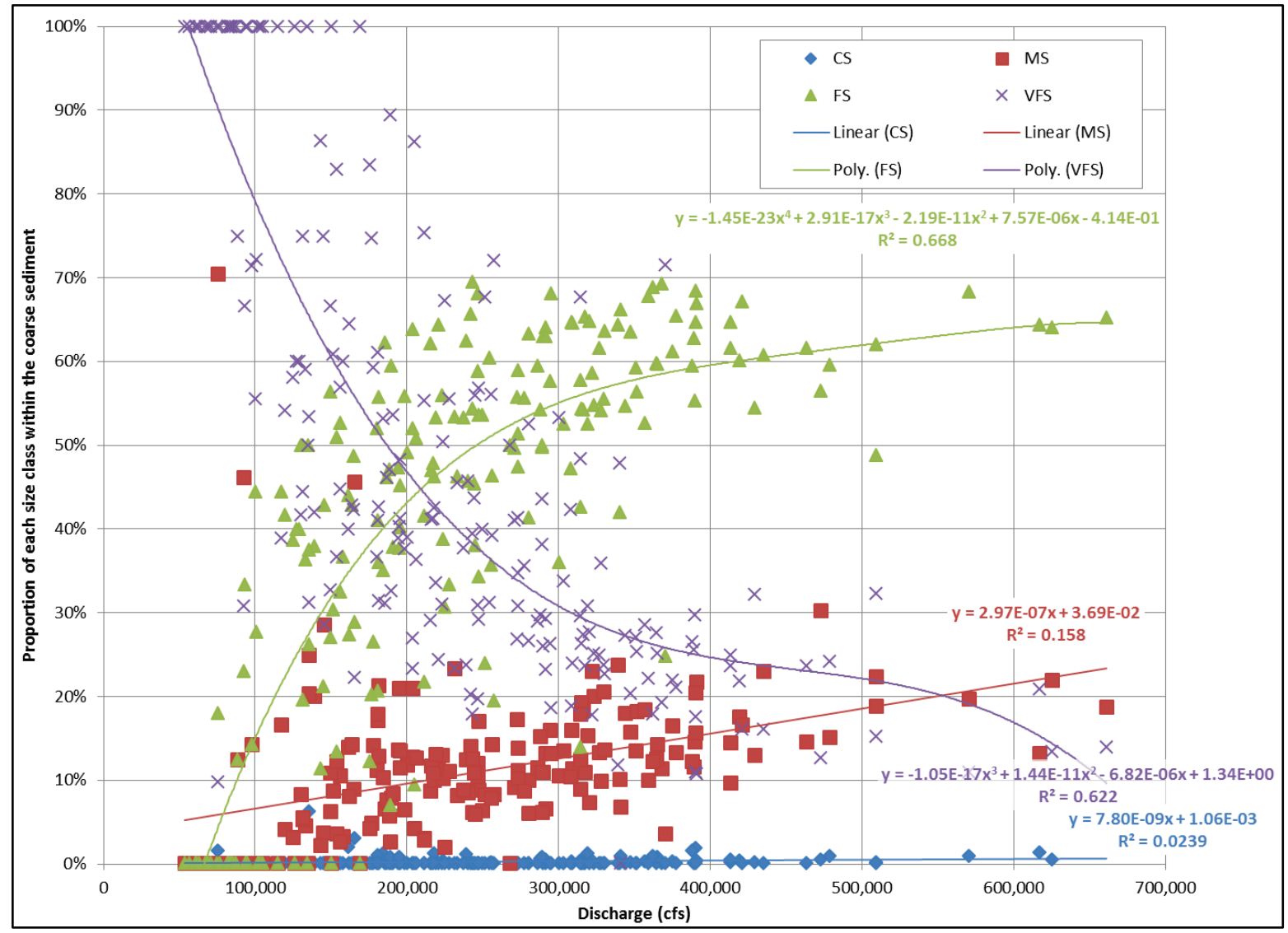

3. The total sediment concentrations, as a function of discharge, were determined using linear regression within a log-log scale plot of the observed data, as seen in Figure 10. The data were bias-corrected so that a linear regression would be properly developed for a log-log relationship. The linear relationship was calculated based on data up to $400,000 \mathrm{cfs}$, and the total concentration is held constant above 400,000 cfs. The change at 400,000 cfs is reasonable because it shows that the wash load becomes supply limited at high discharges. 
Figure 10. Total sediment concentrations at Simmesport, LA.

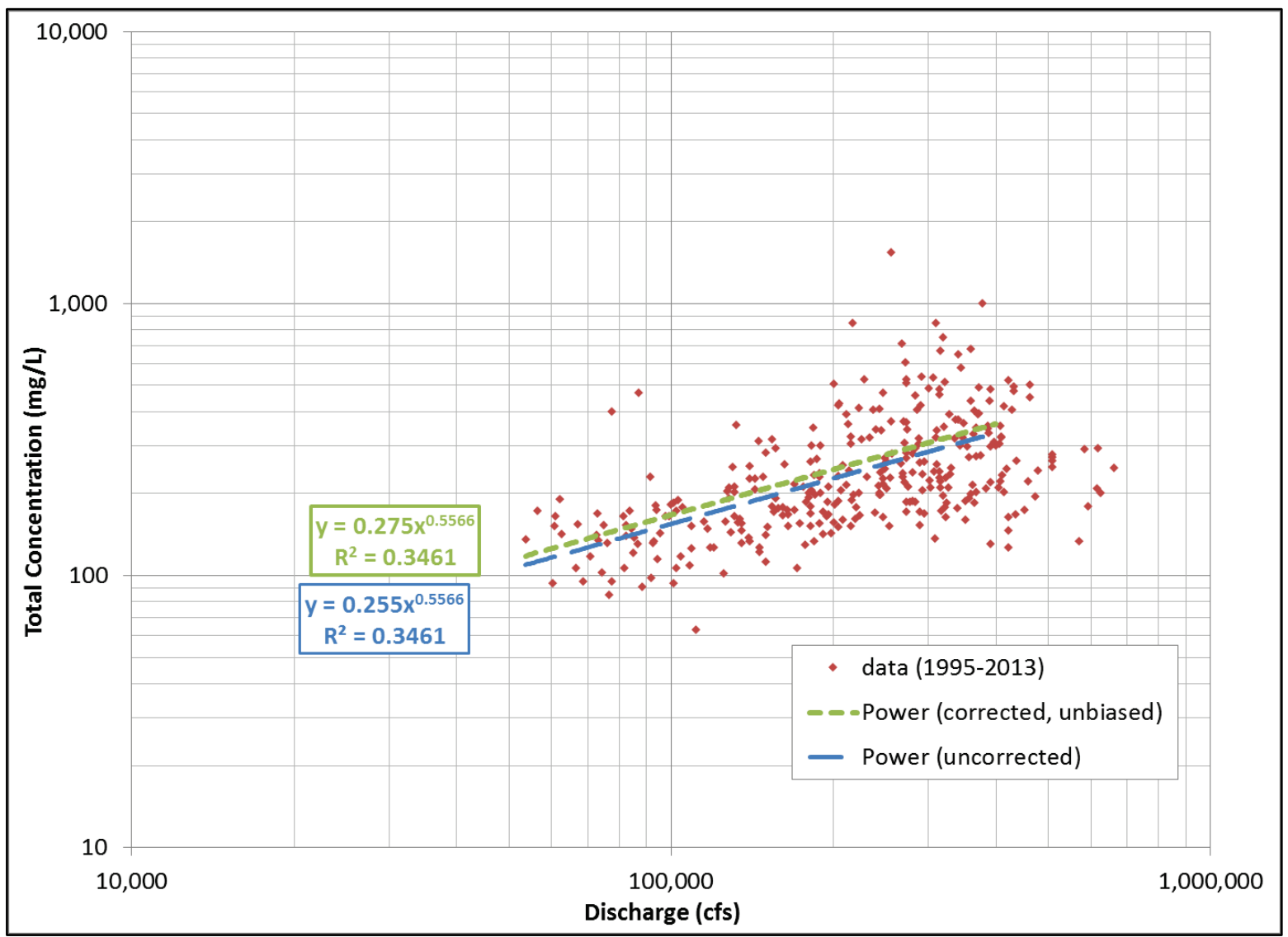

4. The HEC-6T model input requires that a fraction of the total load be assigned to each size class in the model and that the total load be defined with a sediment-discharge rating curve. The sediment-discharge rating curve was taken to be the unbiased total sediment concentration curve. The coarse fraction of the total concentration was determined using the ratio of the unbiased coarse rating curve to the unbiased total rating curve. The fraction for each coarse size class relative to the total sediment concentration was then calculated by multiplying the fractions from Figure 9 by the fraction of the coarse load.

5. The coarse material load was increased by $15 \%$ to account for unmeasured load. Model validation showed that this amount is reasonable.

6. The fine sediment proportions were determined based on linear regression through the measured data, as shown in Figure 11. For discharges above 600,000 cfs, the proportions were held the same as $600,000 \mathrm{cfs}$. The total fine load was taken to be the difference between the total sediment concentration and the coarse sediment concentration. 
Figure 11. Fine sediment proportions for Simmesport, LA (CS: coarse sand; MS: medium sand; FS: fine sand; VFS: very fine sand; CSILT: coarse silt; MSILT: medium silt; FSILT: fine silt; and VFSLT: very fine silt).

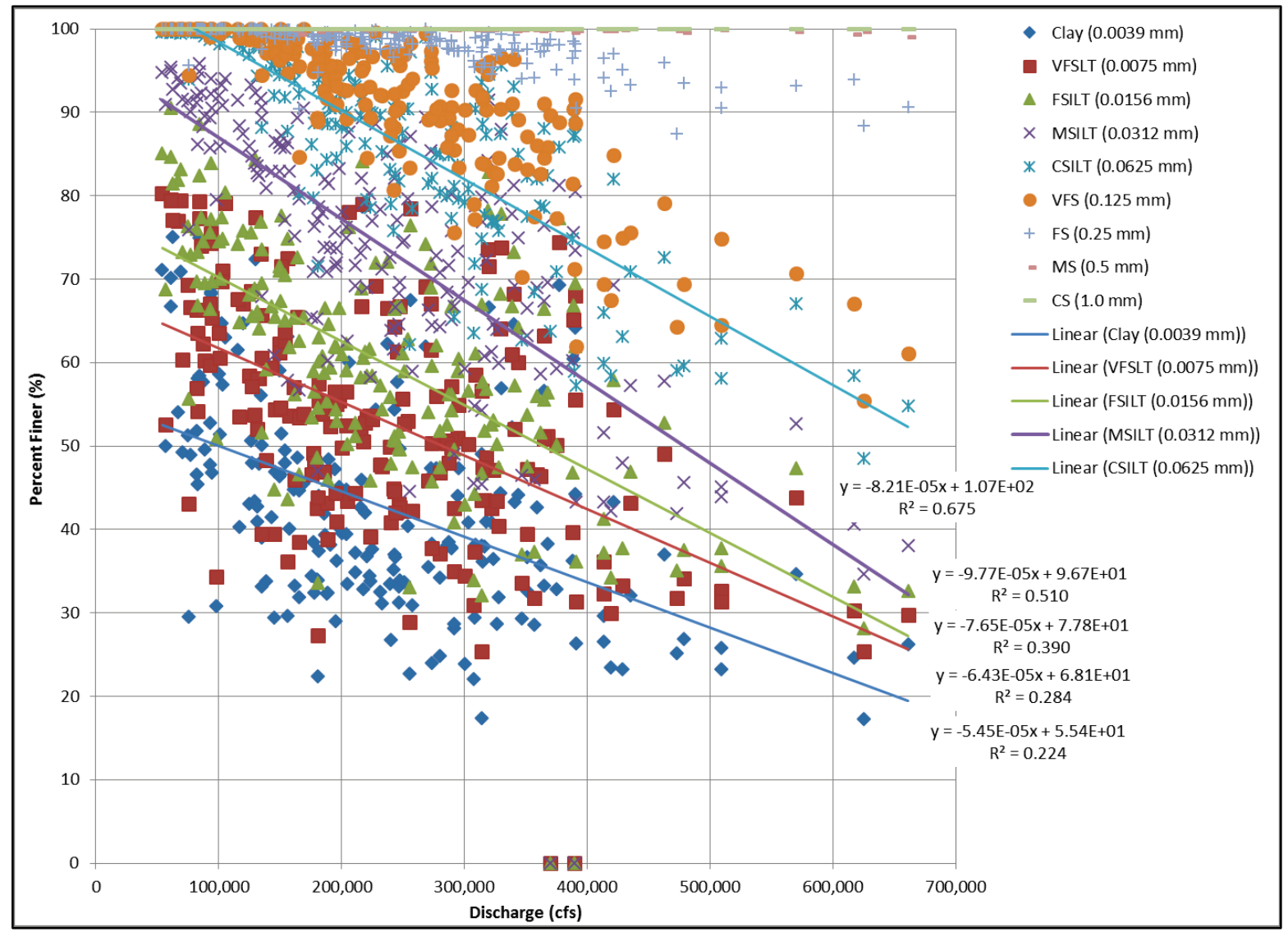

The final sediment inflow relationships used at the upstream boundary of the model are listed in Table 3. The total measured sediment load is shown in the second row. The rows from clay to coarse sand represent the proportion of the total sediment load that consists of that size class. As discussed in step three above, the total load was developed using measured sediment concentration data, but there is also sediment transported in the unmeasured zone. The unmeasured zone includes sediment that is moving very close to the bottom and within the bedload. The summation of the proportions within each column can be greater than 1 because the development of these sediment inflow relationships accounts for coarse material in the unmeasured zone, as mentioned in step 5 above. The HEC-6T model allows for the proportions to add to a value greater than 1 by internally adjusting the total sediment load which actually enters the upstream end of the model according to each size class. 
Table 3. Sediment inflow boundary condition used in the HEC-6T model.

\begin{tabular}{|l|c|c|c|c|c|c|c|}
\hline $\begin{array}{l}\text { Discharge } \\
\text { (cfs) }\end{array}$ & 10,000 & 60,000 & 100,000 & 200,000 & 400,000 & 600,000 & $2,000,000$ \\
\hline $\begin{array}{l}\text { Tons/day } \\
(\mathrm{mg} / \mathrm{L}) *\end{array}$ & $\begin{array}{c}1,665 \\
(62)\end{array}$ & $\begin{array}{c}22,479 \\
(139)\end{array}$ & $\begin{array}{c}47,212 \\
(175)\end{array}$ & $\begin{array}{c}129,227 \\
(240)\end{array}$ & $\begin{array}{c}353,721 \\
(328)\end{array}$ & $\begin{array}{c}530,581 \\
(328)\end{array}$ & $\begin{array}{c}1,768,604 \\
(328)\end{array}$ \\
\hline clay & 0.549 & 0.521 & 0.500 & 0.445 & 0.336 & 0.336 & 0.336 \\
\hline $\begin{array}{l}\text { very fine } \\
\text { silt }\end{array}$ & 0.126 & 0.121 & 0.117 & 0.107 & 0.088 & 0.088 & 0.088 \\
\hline fine silt & 0.096 & 0.090 & 0.085 & 0.073 & 0.048 & 0.048 & 0.048 \\
\hline $\begin{array}{l}\text { medium } \\
\text { silt }\end{array}$ & 0.187 & 0.176 & 0.168 & 0.147 & 0.104 & 0.104 & 0.104 \\
\hline coarse silt & 0.043 & 0.092 & 0.119 & 0.134 & 0.165 & 0.165 & 0.165 \\
\hline $\begin{array}{l}\text { very fine } \\
\text { sand }\end{array}$ & 0.000 & 0.002 & 0.012 & 0.093 & 0.086 & 0.086 & 0.086 \\
\hline fine sand & 0.000 & 0.000 & 0.002 & 0.086 & 0.211 & 0.211 & 0.211 \\
\hline $\begin{array}{l}\text { medium } \\
\text { sand }\end{array}$ & 0.000 & 0.000 & 0.001 & 0.019 & 0.055 & 0.055 & 0.055 \\
\hline $\begin{array}{l}\text { coarse } \\
\text { sand }\end{array}$ & 0.000 & 0.000 & 0.000 & 0.001 & 0.001 & 0.001 & 0.001 \\
\hline
\end{tabular}

*milligrams per liter

\subsubsection{Morganza Control Structure (MCS)}

The MCS, or the Morganza Floodway, is another boundary condition flowing into the model. The 2010 HEC-6T model introduced the entire amount of Morganza flow into the location where the levee ends, just upstream of the Whiskey Bay Pilot Channel. Comparing results of water flow in the channel of the HEC-RAS model, which had modeled the Morganza Floodway with 2D flow elements, showed that the HEC-6T model was carrying too much flow in the channel through the reach beginning at that location. The Morganza flow stays in the floodway to the east of the Atchafalaya River for much longer. The lidar surface elevations were evaluated for potential locations where the Morganza flow could enter the HEC-6T model. An AdH hydraulic model under development for the Atchafalaya River Basin was also evaluated (phase two of the work by Bell et al. [2017]). After evaluating the terrain and the $2 \mathrm{D}$ modeling results, it was decided to distribute the MCS flow to the Lower Atchafalaya River into three different cross sections between the junction with Wax Lake Outlet Channel and Morgan City, namely into cross sections -104.8, -112.5, and -120.1. 
The timing of flow through MCS is different than the timing of flow entering into the Lower Atchafalaya River. The total volume of flow through MCS, based on Table 10 of Maynord (2014), was used to simulate the proper volume of water discharge during the 2011 event. To determine the proper attenuation of the MCS flow arriving to the Atchafalaya River channel, the 2011 observed data for Morgan City and Calumet were used. First, the HEC-6T model was simulated without any MCS inflow for the 2011 event. These results showed a clear deficit of water volume at both Morgan City and Calumet beginning on 21 May 2011, which is lagged from the reported flow through MCS beginning on 14 May 2011. Then the difference in volume between simulated (Morgan City plus Calumet) and observed (Morgan City plus Calumet) was calculated. This calculated difference in discharge was used as the HEC-6T inflow until its accumulated volume matched the total volume reported in Table 10 of Maynord (2014). The HEC-6T model was rerun with the new MCS flows to check the simulation with observed flows at Morgan City and Calumet, as seen in Figure 12.

Sediment inflow through the MCS came from the Mississippi River HEC$6 \mathrm{~T}$ model, using what was diverted out of that model, for consistency. The MCS sediment inflow boundary condition contains only fine material, $43 \%$ clay and $57 \%$ silt. 
Figure 12. Observed and simulated flows through (a) Morgan City and (b) Calumet during the 2011 flood.
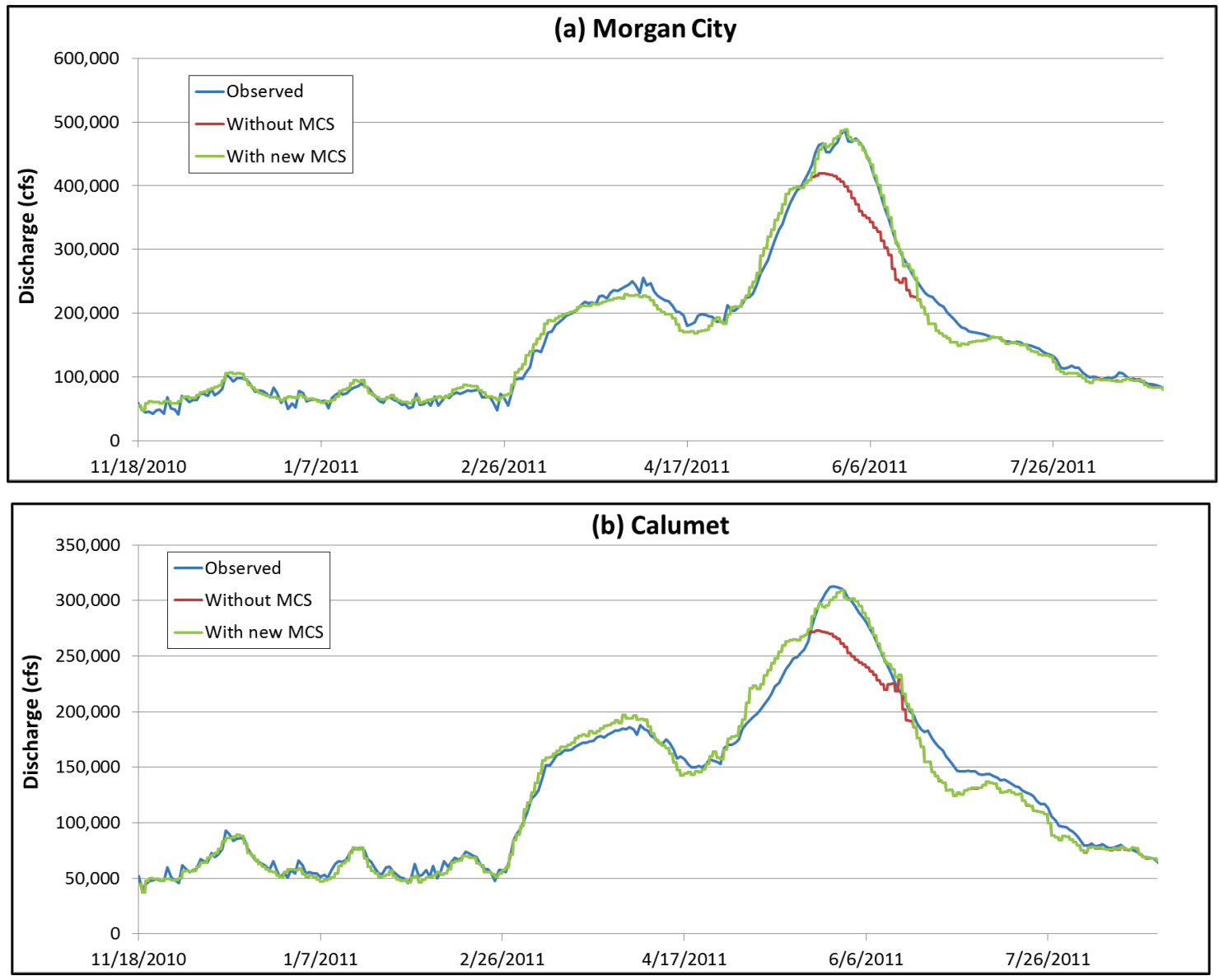

\subsubsection{Gulf of Mexico}

The 2010 HEC-6T model used daily water level data from the Eugene Island gage from 1997 through 2007. Data were retrieved from the National Oceanic and Atmospheric Administration (NOAA) Tides and Currents website (Station IDs 8764311 and 8764314) where available. Data were also provided by MVN to fill in some of the gaps of available data from the NOAA website. A remaining gap for 12 December 2013 through 1 April 2015 was filled using a value of $0.5 \mathrm{ft}$, calculated from averaging the available data in the neighboring years 2013 and 2015.

Since the Wax Lake Outlet Channel was significantly shortened in this study to better represent the 1D flow, as discussed in Section 2.2.1, an offset was used between the Eugene Island data and stage used at the downstream end of the Wax Lake Outlet Channel. The offset was calculated to be $0.3 \mathrm{ft}$ from evaluating the water surface differences in the HEC-6T model before eliminating the downstream cross sections. The 
downstream water surface boundary condition was $0.3 \mathrm{ft}$ higher for the Wax Lake Outlet Channel (Segment 2) than the Lower Atchafalaya River (Segment 1) for each time-step.

\subsection{Roughness coefficients}

The hydraulic calibration was achieved by adjusting roughness, or Manning's $n$, values such that the simulation of 1997 to 2010 represented the observed data. At the downstream end, the roughness values in the Lower Atchafalaya River and Wax Lake Outlet Channel influence not only the water surfaces in those channels but also the flow distribution between the two channels. Manning's $n$ values, varying as a function of discharge, in the downstream segments of the model were specified and adjusted during calibration. The gages at Calumet (stage and discharge), Morgan City (stage and discharge), and Avoca Island (stage only) were used for calibrating roughness values in the downstream end of the model. Parallel channels exist through the large bend in the Lower Atchafalaya River upstream from Morgan City. Laterally specified roughness values were decreased within the side channel areas of those cross sections, and the island areas between channels remained relatively rough. Roughness values were only slightly adjusted from the 2010 HEC-6T model in other, upstream segments during the calibration process.

\subsection{Transport functions}

Final model results were generated using the Laursen-Copeland method for sand transport. Other transport functions, which were implemented during the calibration phase to compare their effects, were the Toffaleti, EngelundHansen, Ackers-White, Madden-Laursen 1963, and Madden-Laursen 1985. All of the different transport functions gave very similar results in terms of sand concentrations at gage locations and bed elevation changes. Figure 13 shows a comparison of sand concentration at Morgan City with two of the most commonly used transport functions: Laursen-Copeland and Toffaleti. The sand concentration comparison at Melville showed that the EngelundHansen transport function showed a higher sand concentration than the other transport functions, and it also had a flatter slope to the data on the log-log plot of discharge vs. sand concentration. 
Figure 13. Comparison of computed sand concentrations using the a) LaursenCopeland and b) Toffaleti transport functions.
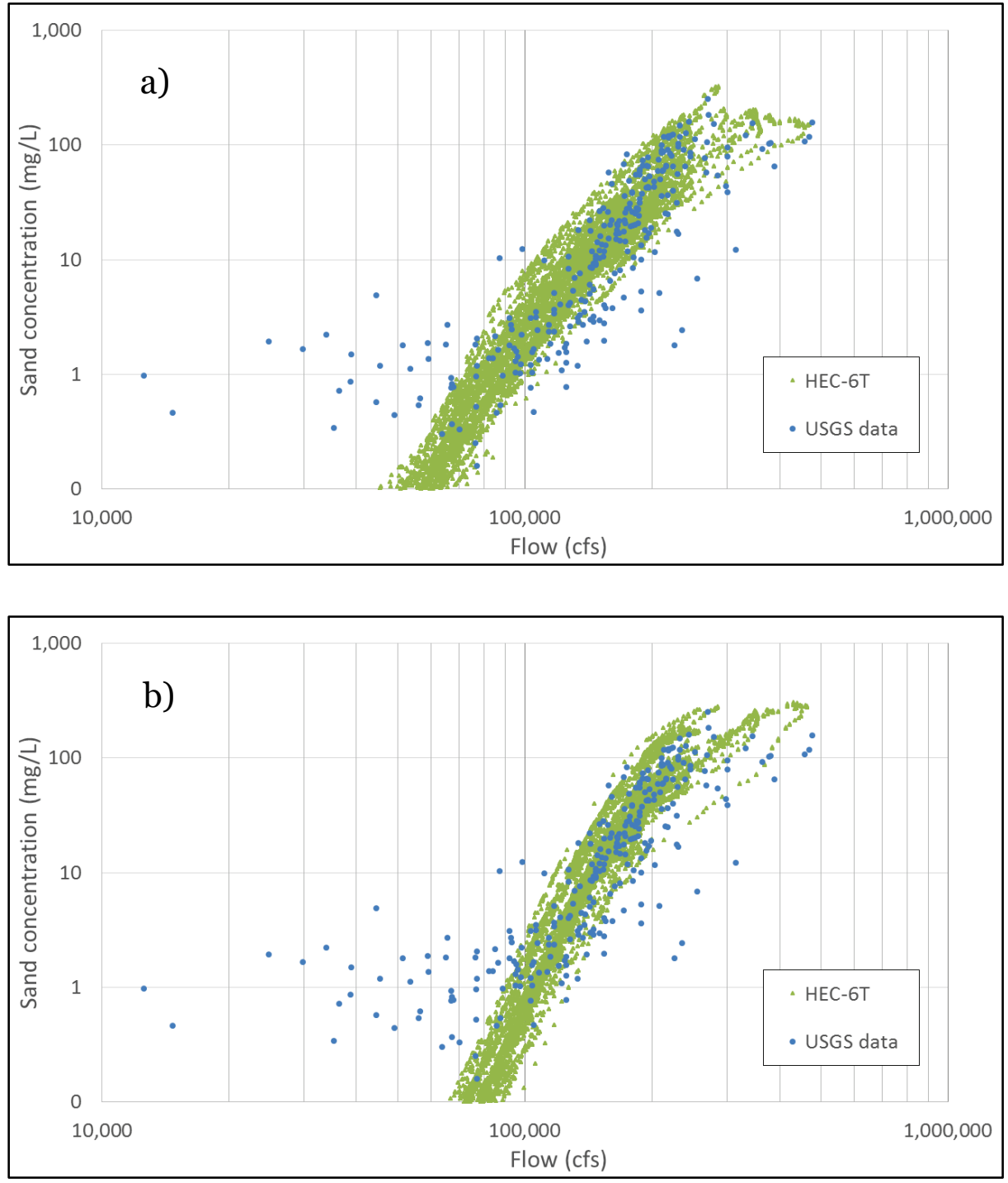

\subsection{Results}

The calibration and validation results agree with observed stage, discharge, and sediment concentration data at gage locations. Stage and discharge results are shown in Figure 14 through Figure 23. The root mean square error (RMSE) and the Nash-Sutcliffe Efficiency (NSE) coefficient were calculated to quantify errors between observed and computed data, as shown in Table 4. The NSE can range from $-\infty$ to 1 , with a value of 1 corresponding to a perfect match between modeled and observed data. The RMSE and NSE coefficient were calculated between the modeled and observed sediment data, as shown in Table 5. Total sediment and sand concentrations are shown in Figure 24 through Figure 
31. Many of the computed sand concentrations are higher than the observed sand concentrations, especially at lower discharges. This can be attributed to the fact that the HEC-6T results include both sand moving along the bed and suspended sand whereas the observed data include only the measured suspended sand. Figure 32 through Figure 35 also show comparisons between the observed and computed sediment concentrations at the four locations.

Table 4. Metrics for hydraulic differences between computed and observed values (RMSE measures the error between the computed and observed values. NSE measures the predictive power of the model. Blank cells indicate that observations are not available.)

\begin{tabular}{|l|c|c|c|c|c|c|}
\hline & \multicolumn{2}{|c|}{ Water Surface Elevation } & \multicolumn{3}{c|}{ Discharge } \\
\cline { 2 - 7 } Location & $\begin{array}{c}\text { Average } \\
\text { Bias* } \\
\text { (ft) }\end{array}$ & $\begin{array}{c}\text { RMSE } \\
\text { (ft) }\end{array}$ & NSE & $\begin{array}{c}\text { Average } \\
\text { Bias* } \\
\text { (cfs) }\end{array}$ & $\begin{array}{c}\text { RMSE } \\
\text { (cfs) }\end{array}$ & NSE \\
\hline $\begin{array}{l}\text { Avoca Island Cutoff } \\
\text { south of Morgan } \\
\text { City, LA }\end{array}$ & 0.15 & 0.47 & 0.481 & & & \\
\hline $\begin{array}{l}\text { Lower Atchafalaya } \\
\text { River at Morgan City, } \\
\text { LA }\end{array}$ & -0.47 & 0.66 & 0.842 & -890 & 14,270 & 0.951 \\
\hline $\begin{array}{l}\text { Wax Lake Outlet at } \\
\text { Calumet, LA }\end{array}$ & -0.54 & 0.70 & 0.842 & 1840 & 11,080 & 0.957 \\
\hline $\begin{array}{l}\text { Myette Point near } \\
\text { Charenton, LA }\end{array}$ & 0.46 & 0.64 & 0.948 & & & \\
\hline Butte La Rose, LA & 1.10 & 1.30 & 0.937 & & & \\
\hline Melville, LA & 0.14 & 0.72 & 0.990 & & & \\
\hline Simmesport, LA & -0.19 & 0.78 & 0.993 & & 810 & $1.000 * *$ \\
\hline
\end{tabular}

*The average bias is based on computed minus observed data.

${ }^{*}$ Agreement is due to using the observed data only a few miles away as the boundary condition. 
Table 5. Metrics for sediment differences between computed and observed values. (RMSE measures the error between the computed and observed values. NSE measures the predictive power of the model.)

\begin{tabular}{|l|c|c|c|c|c|c|}
\hline & \multicolumn{3}{|c|}{ Sand Concentration } & \multicolumn{2}{c|}{ Total Concentration } \\
\cline { 2 - 7 } & $\begin{array}{c}\text { Average } \\
\text { Bias* } \\
\text { Location }\end{array}$ & $\begin{array}{c}\text { RMSE } \\
(\mathrm{mg} / \mathrm{L})\end{array}$ & NSE & $\begin{array}{c}\text { Average } \\
\text { Bias* } \\
(\mathrm{mg} / \mathrm{L})\end{array}$ & $\begin{array}{c}\text { RMSE } \\
(\mathrm{mg} / \mathrm{L})\end{array}$ & NSE \\
\hline $\begin{array}{l}\text { Lower Atchafalaya } \\
\text { River at Morgan City, } \\
\text { LA }\end{array}$ & -4.9 & 26.2 & 0.51 & -56.1 & 141.7 & -1.54 \\
\hline $\begin{array}{l}\text { Wax Lake Outlet at } \\
\text { Calumet, LA }\end{array}$ & 24.1 & 37.6 & 0.45 & -23.0 & 117.6 & -0.93 \\
\hline Melville, LA & 12.8 & 32.2 & 0.62 & 23.4 & 97.4 & -0.19 \\
\hline Simmesport, LA & -10.4 & 50.9 & -0.72 & -86.9 & 165.1 & -0.98 \\
\hline
\end{tabular}

*The average bias is based on computed minus observed data.

${ }^{*}$ Agreement is due to using the observed data only a few miles away as the boundary condition. 
Figure 14. Simulated and observed water surfaces for the Avoca Island Cutoff south of Morgan City, LA.

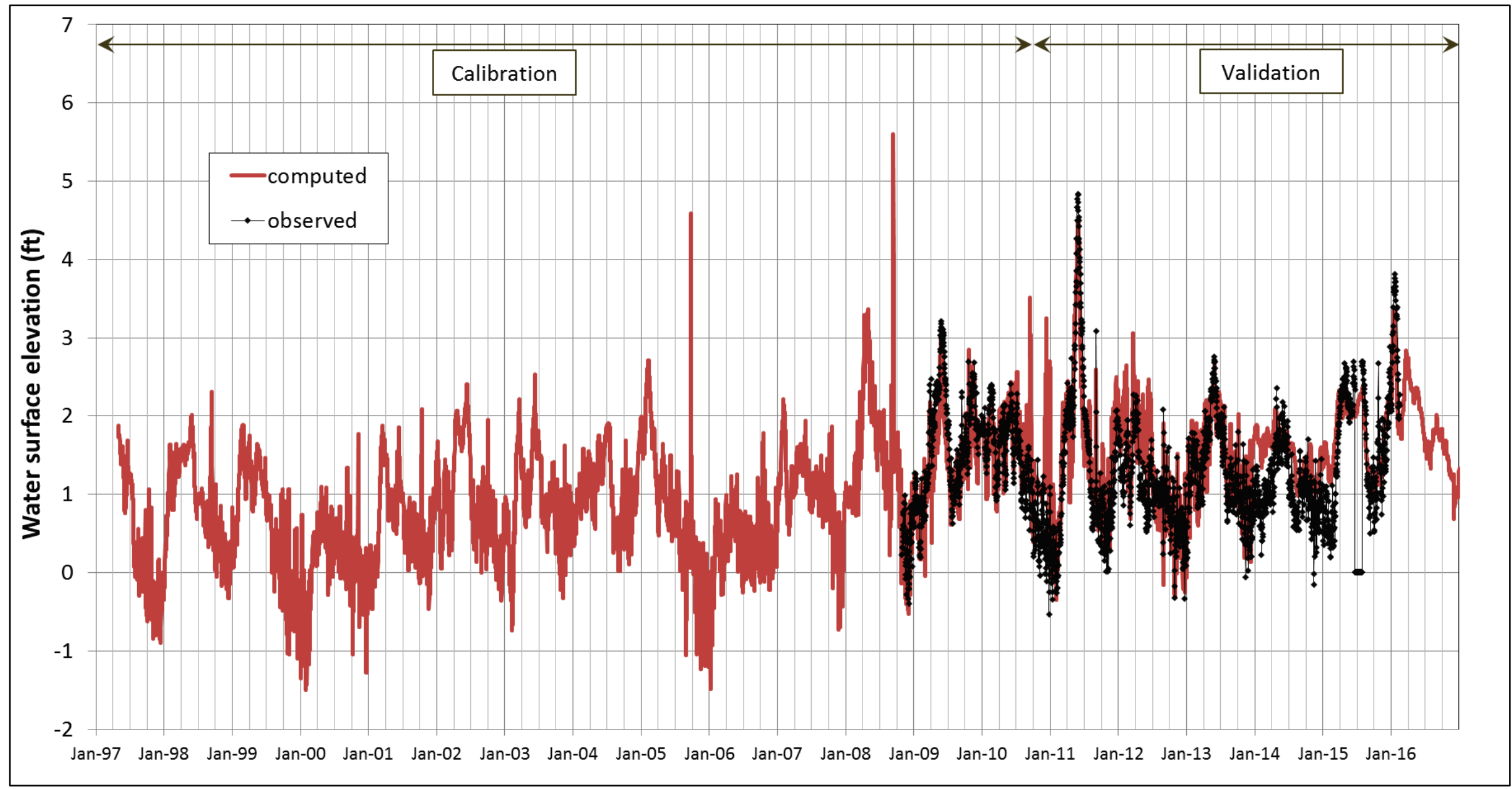

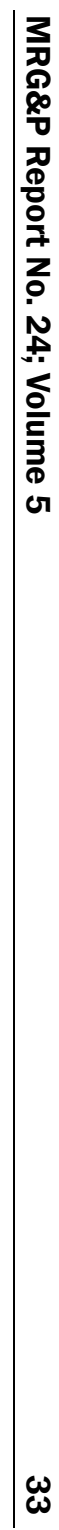


MWHWWWWWWW: 


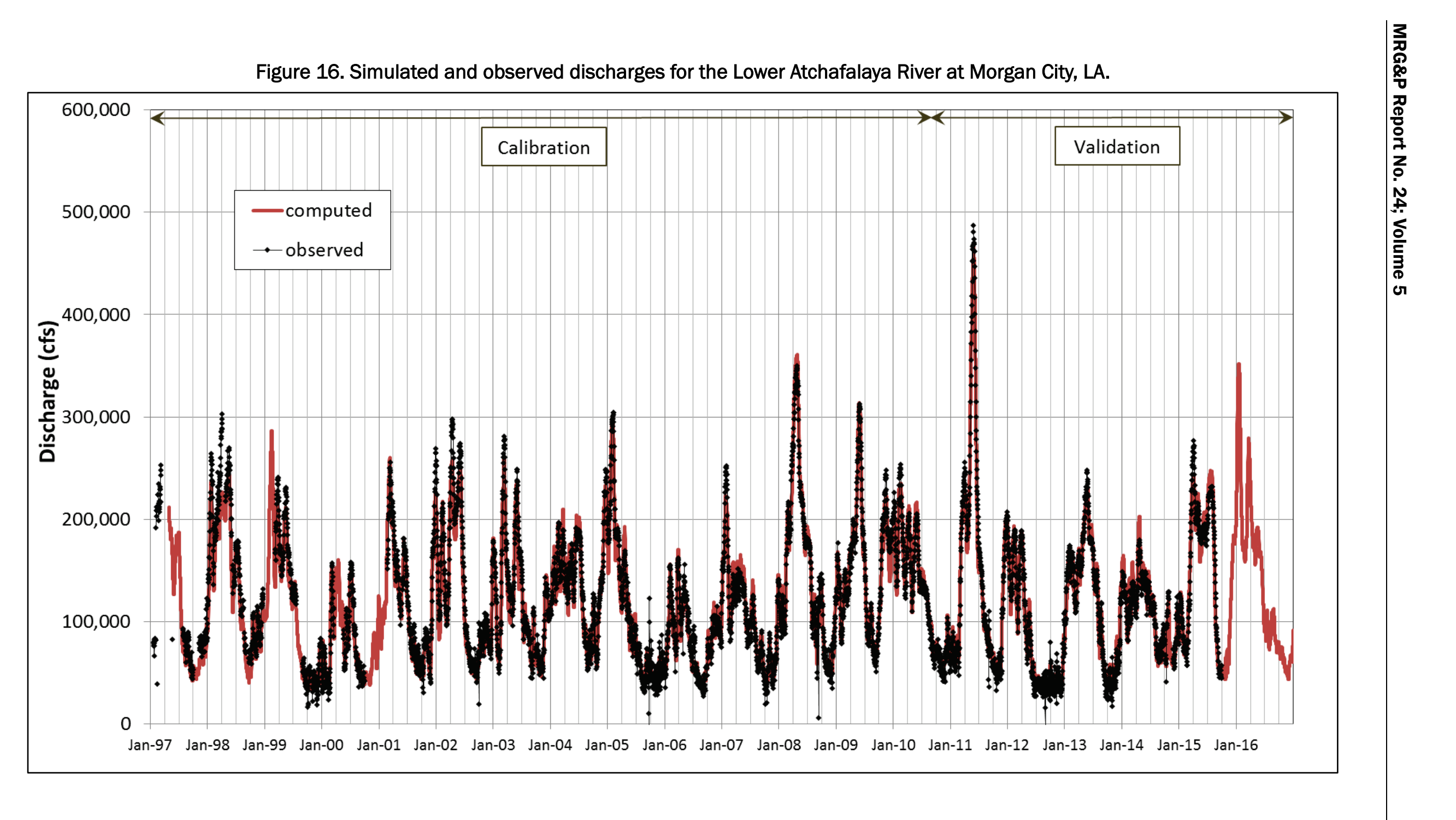




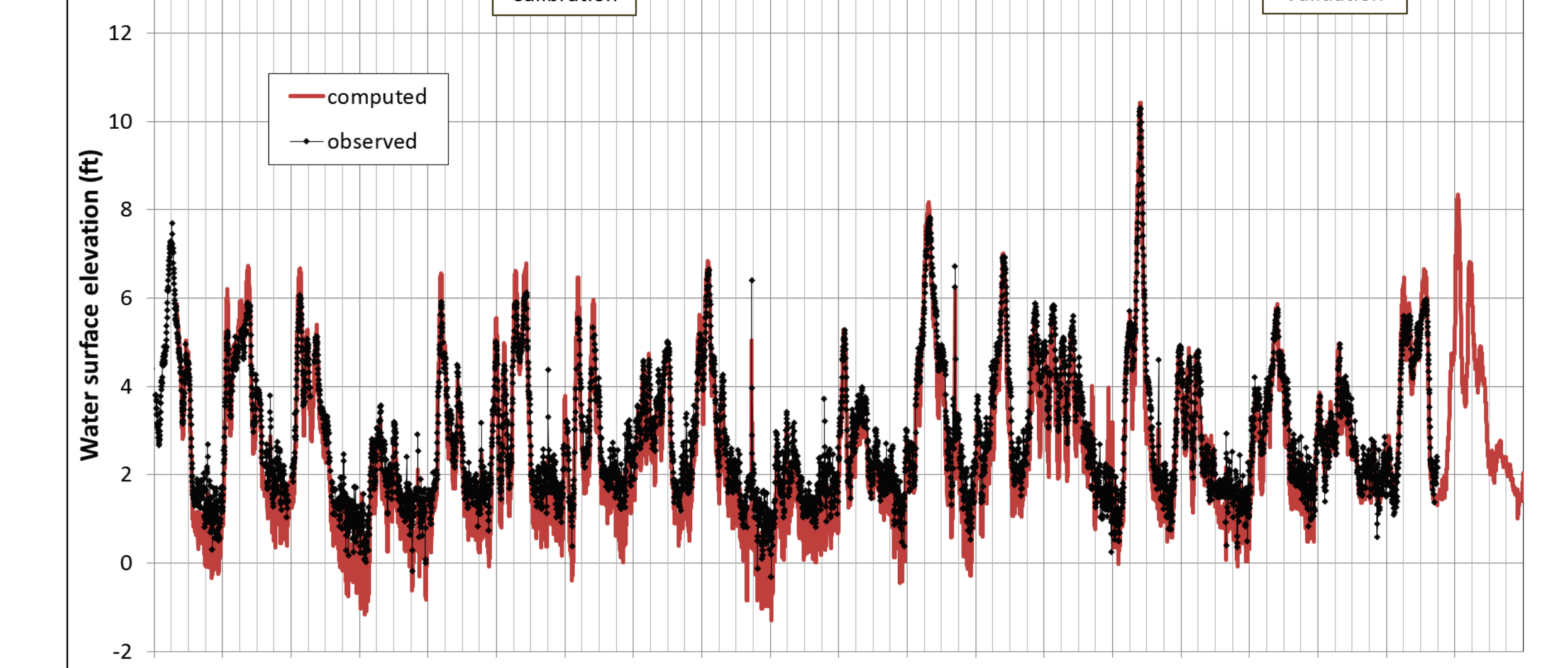


Figure 18. Simulated and observed discharges for the Wax Lake Outlet at Calumet, LA.

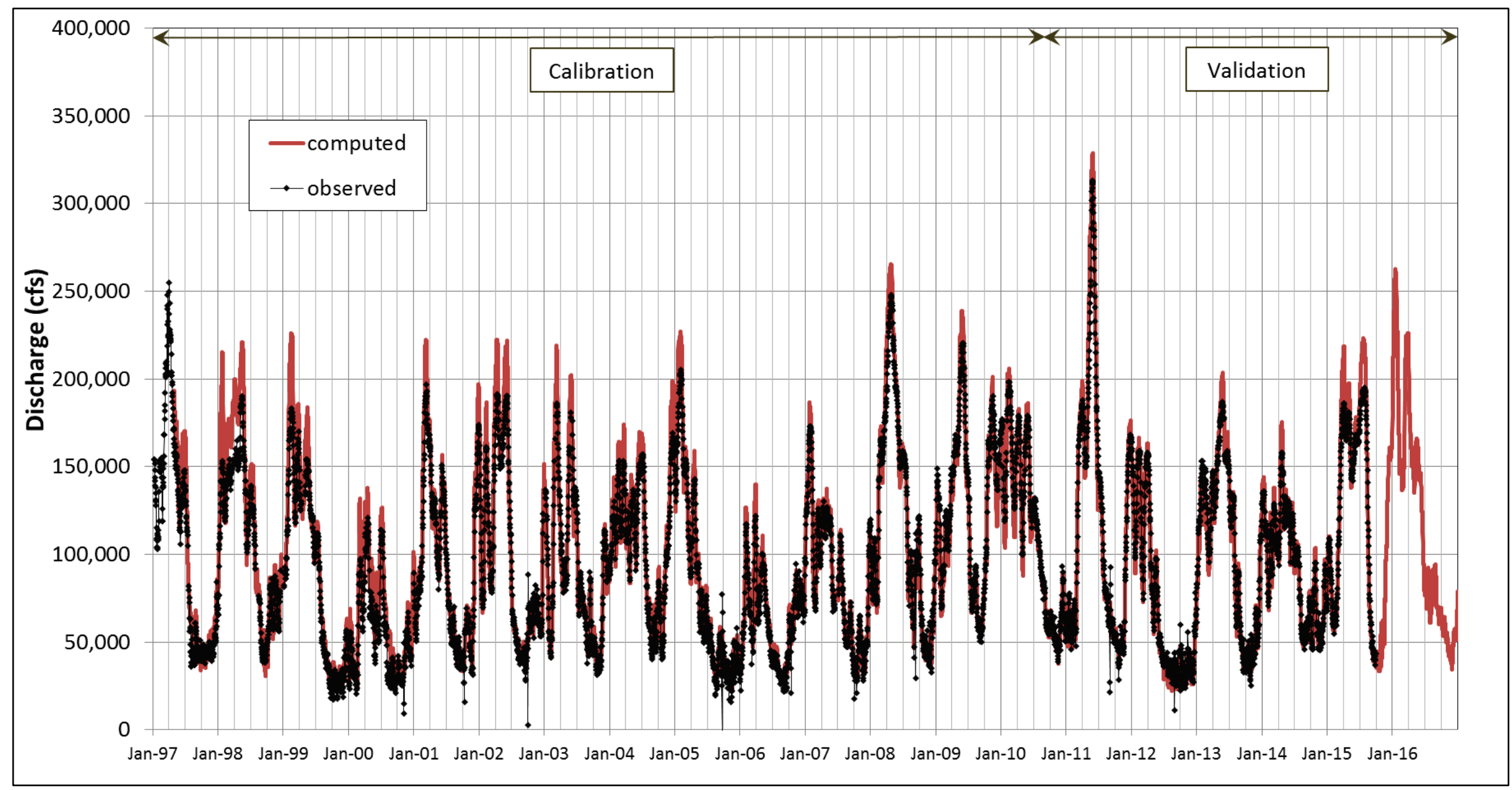


Figure 19. Simulated and observed water surfaces near Myette Point near Charenton, LA.

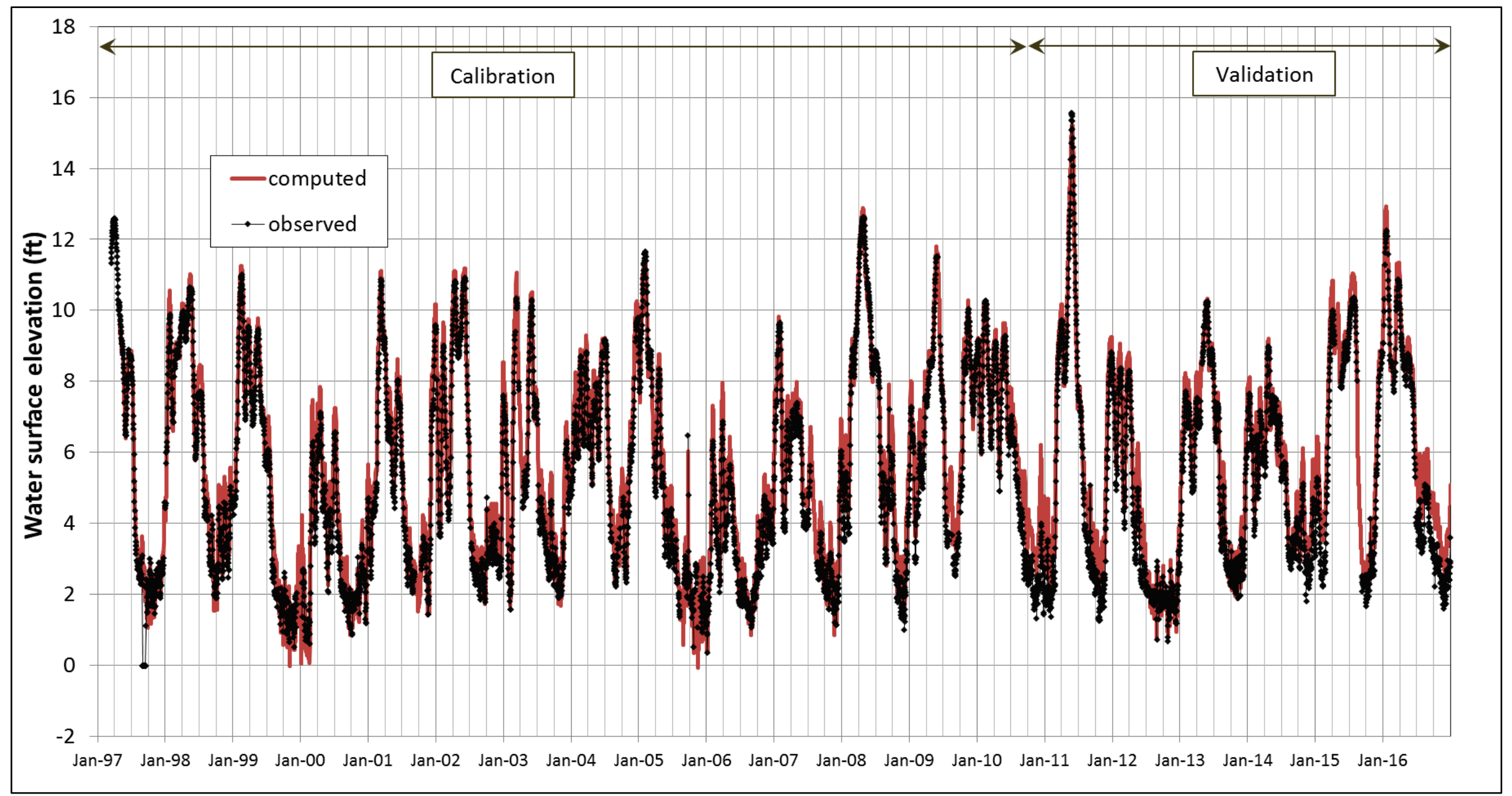


Figure 20. Simulated and observed water surfaces for the Atchafalaya River near Butte La Rose, LA.

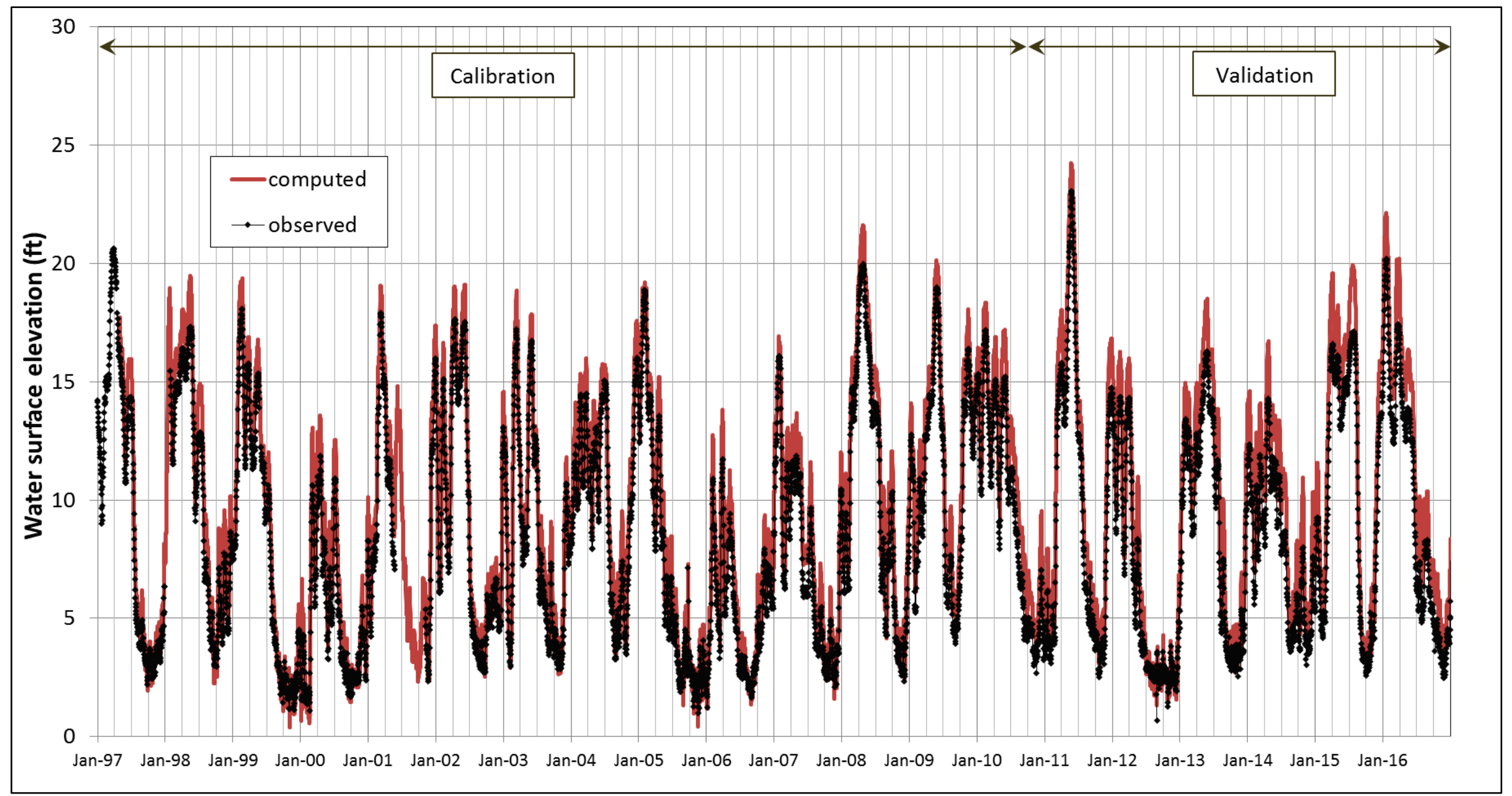

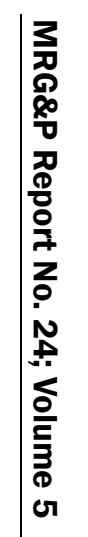


Figure 21. Simulated and observed water surfaces for the Atchafalaya River at Melville, LA.

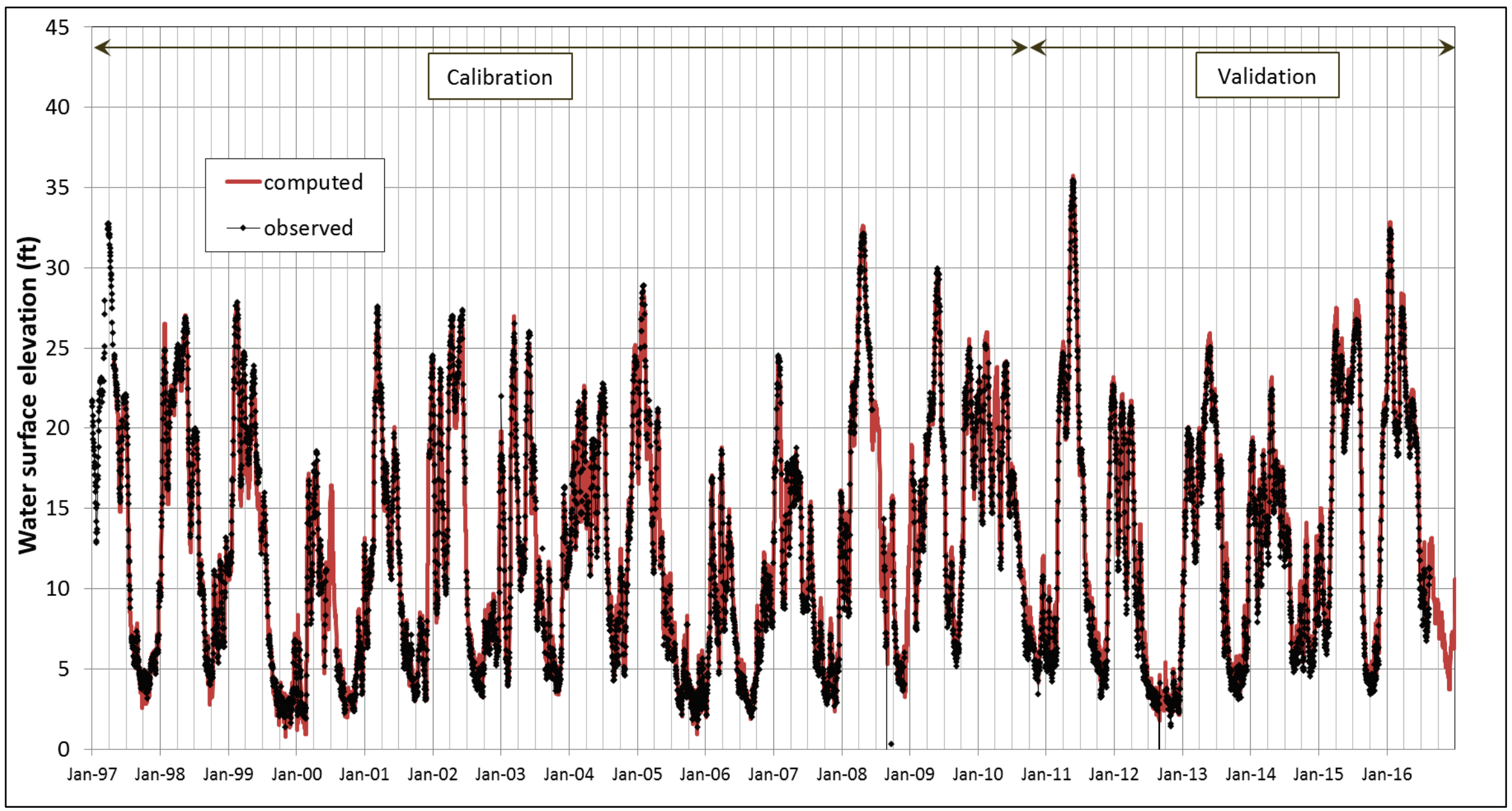


Figure 22. Simulated and observed water surfaces for the Atchafalaya River at Simmesport, LA.

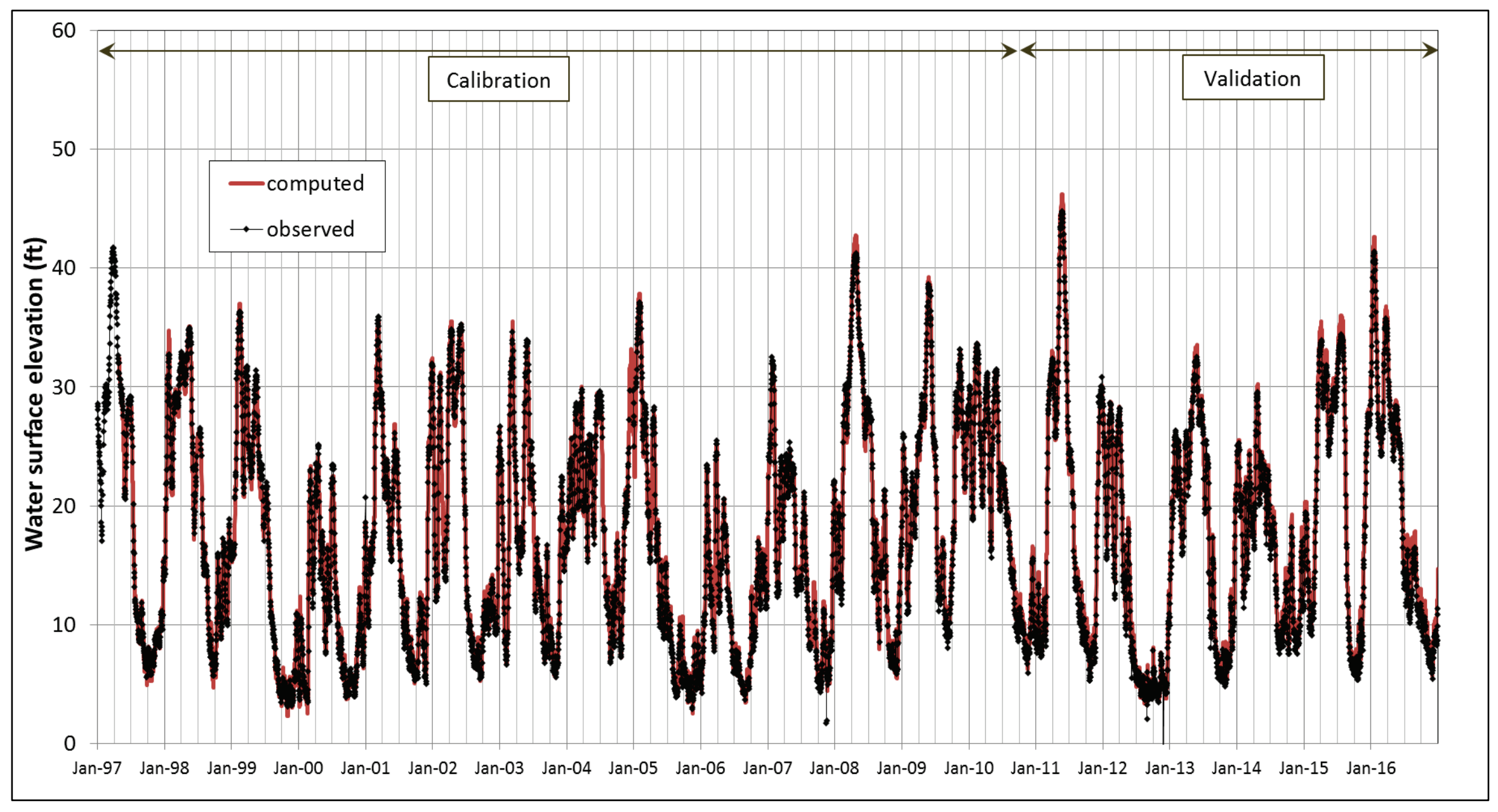


Figure 23. Simulated and observed discharges for the Atchafalaya River at Simmesport. LA.

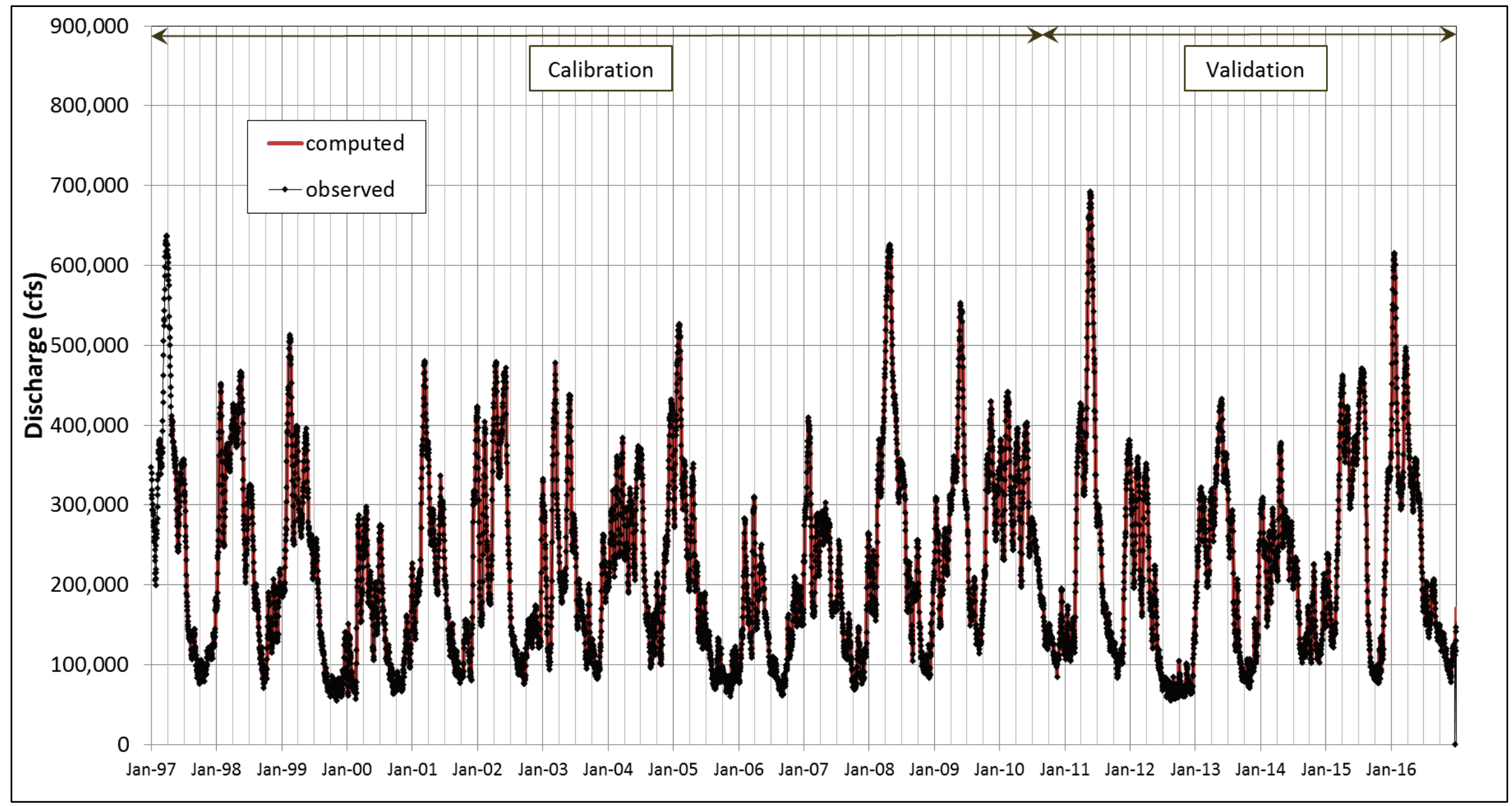

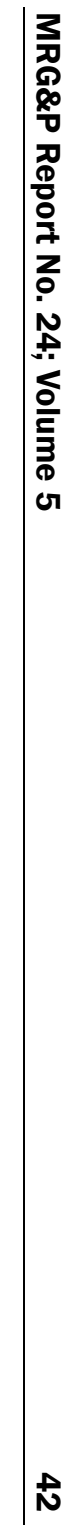


Figure 24. Coarse sediment concentrations for the Lower Atchafalaya River at Morgan City, LA, for 1997-2016.

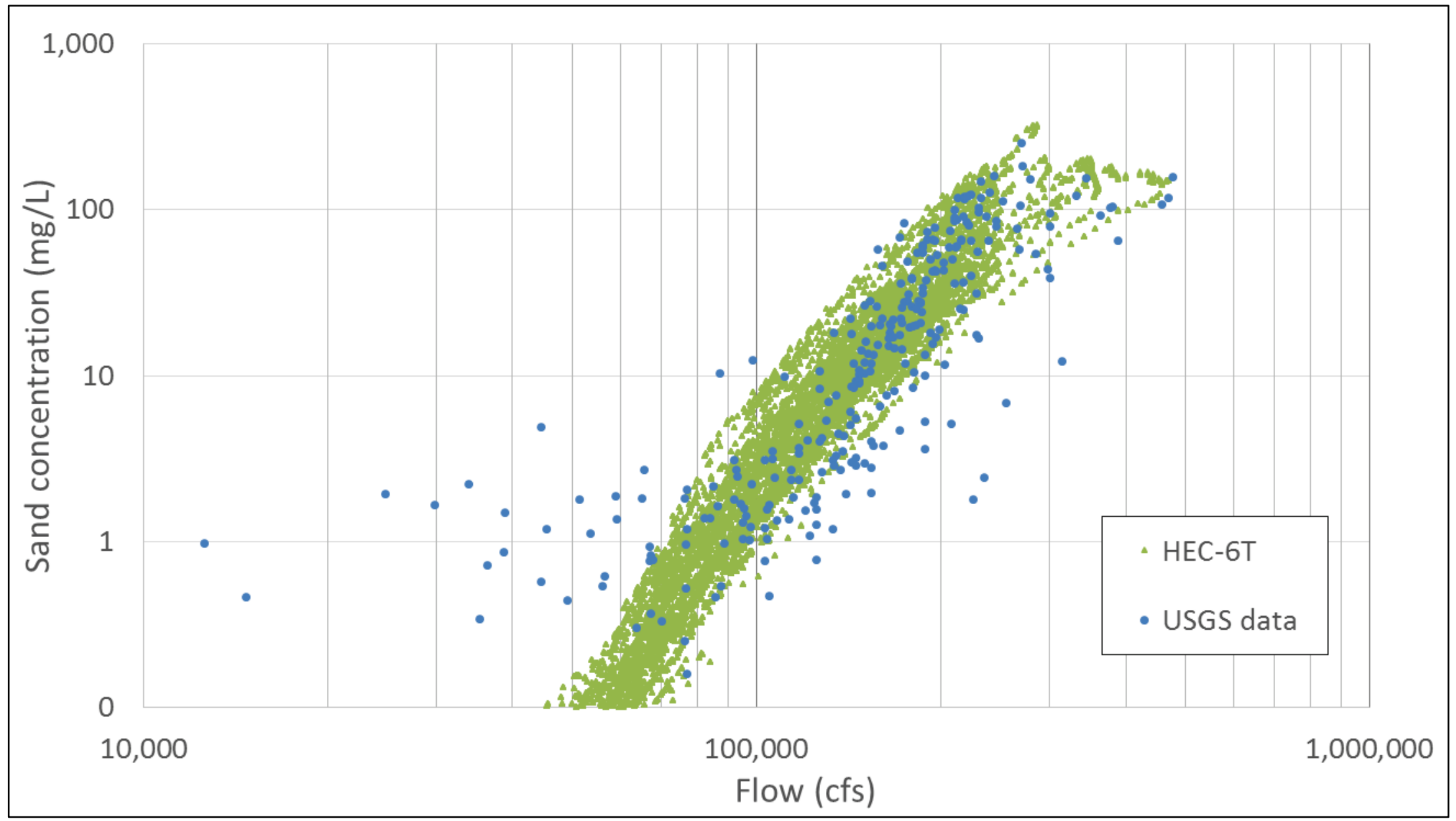


Figure 25. Total sediment concentrations for the Lower Atchafalaya River at Morgan City, LA, for 1997-2016.

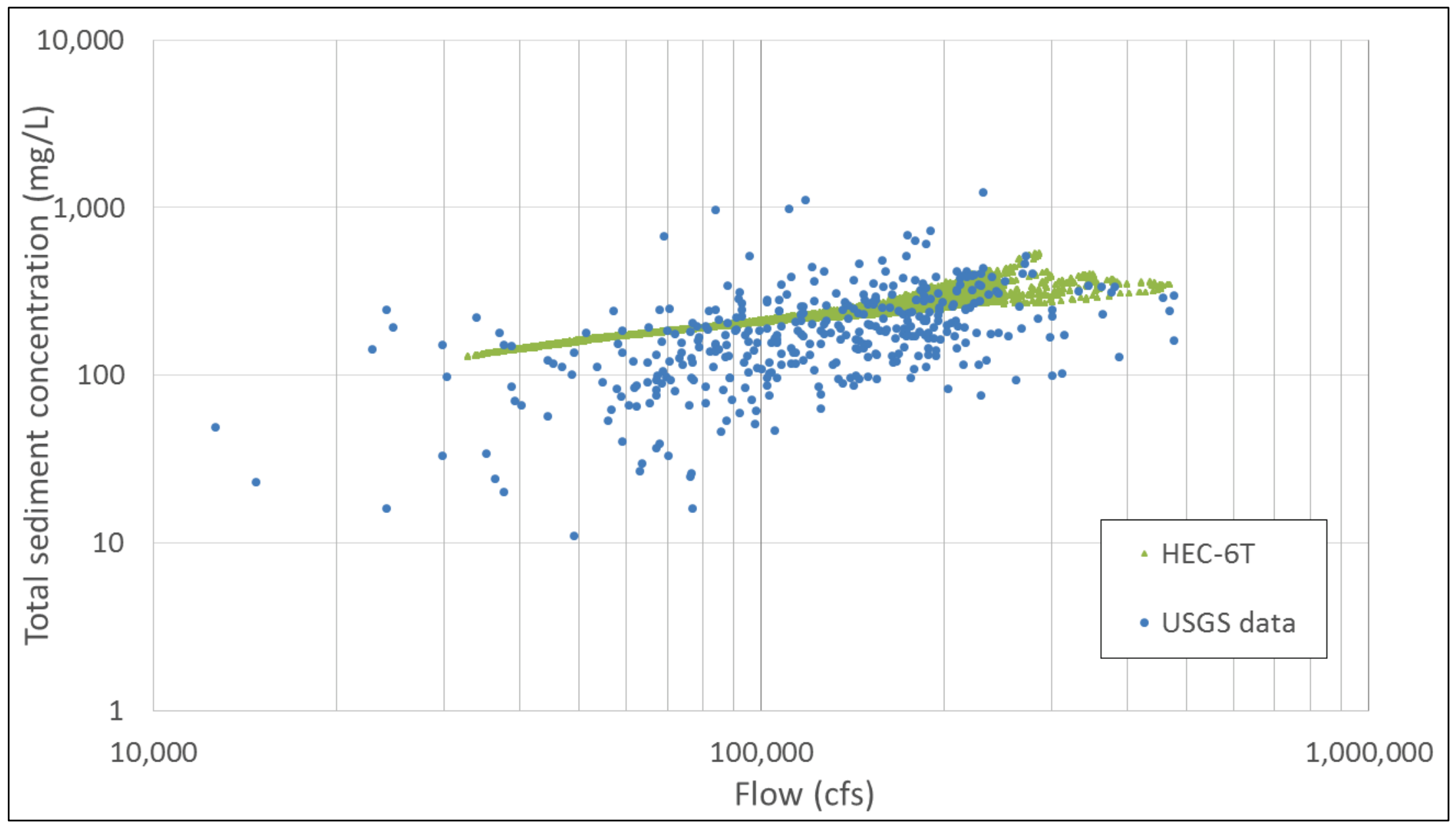


Figure 26. Coarse sediment concentrations for the Wax Lake Outlet at Calumet, LA, for 1997-2016.

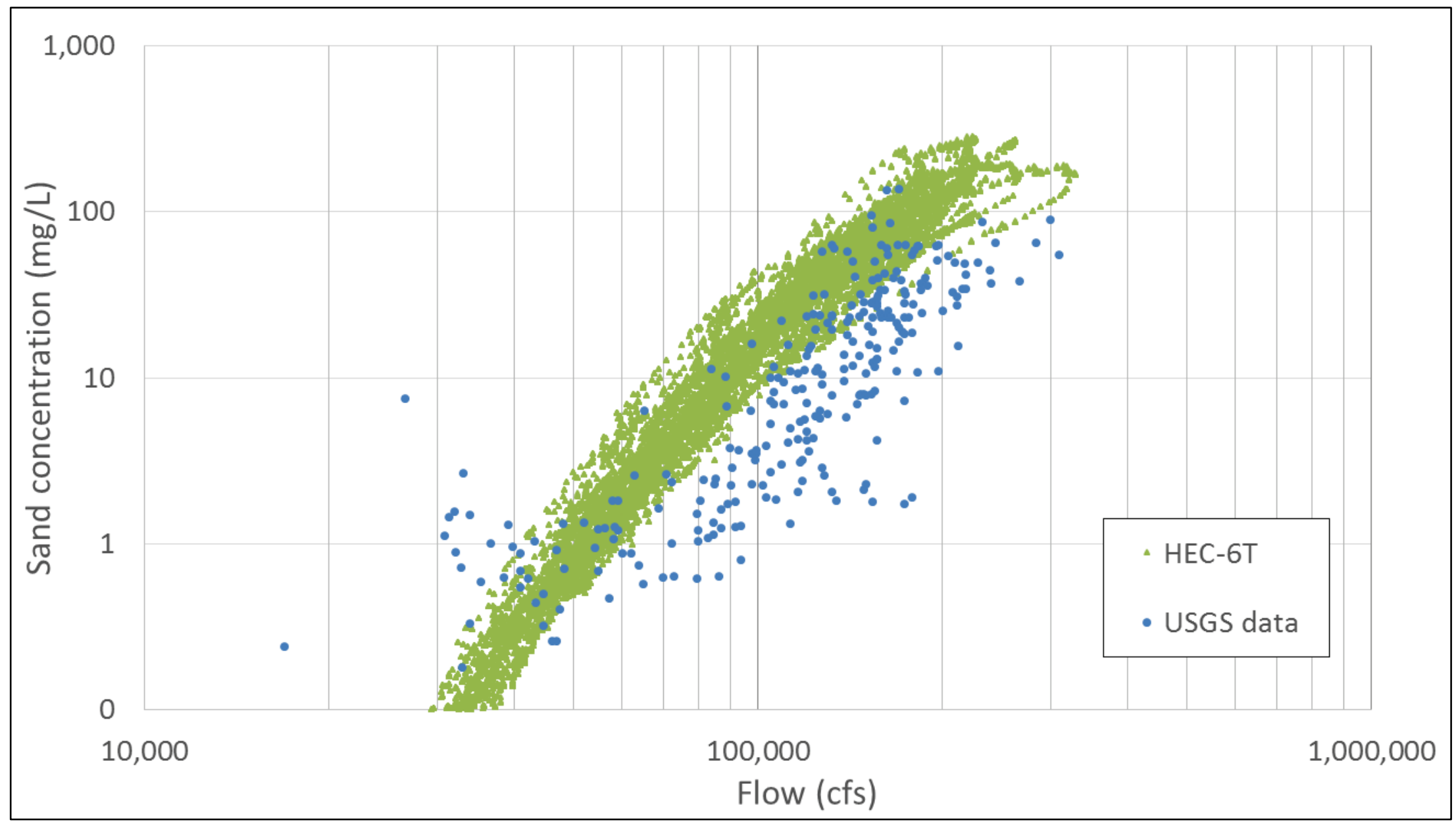


Figure 27. Total sediment concentrations for the Wax Lake Outlet at Calumet, LA, for 1997-2016.

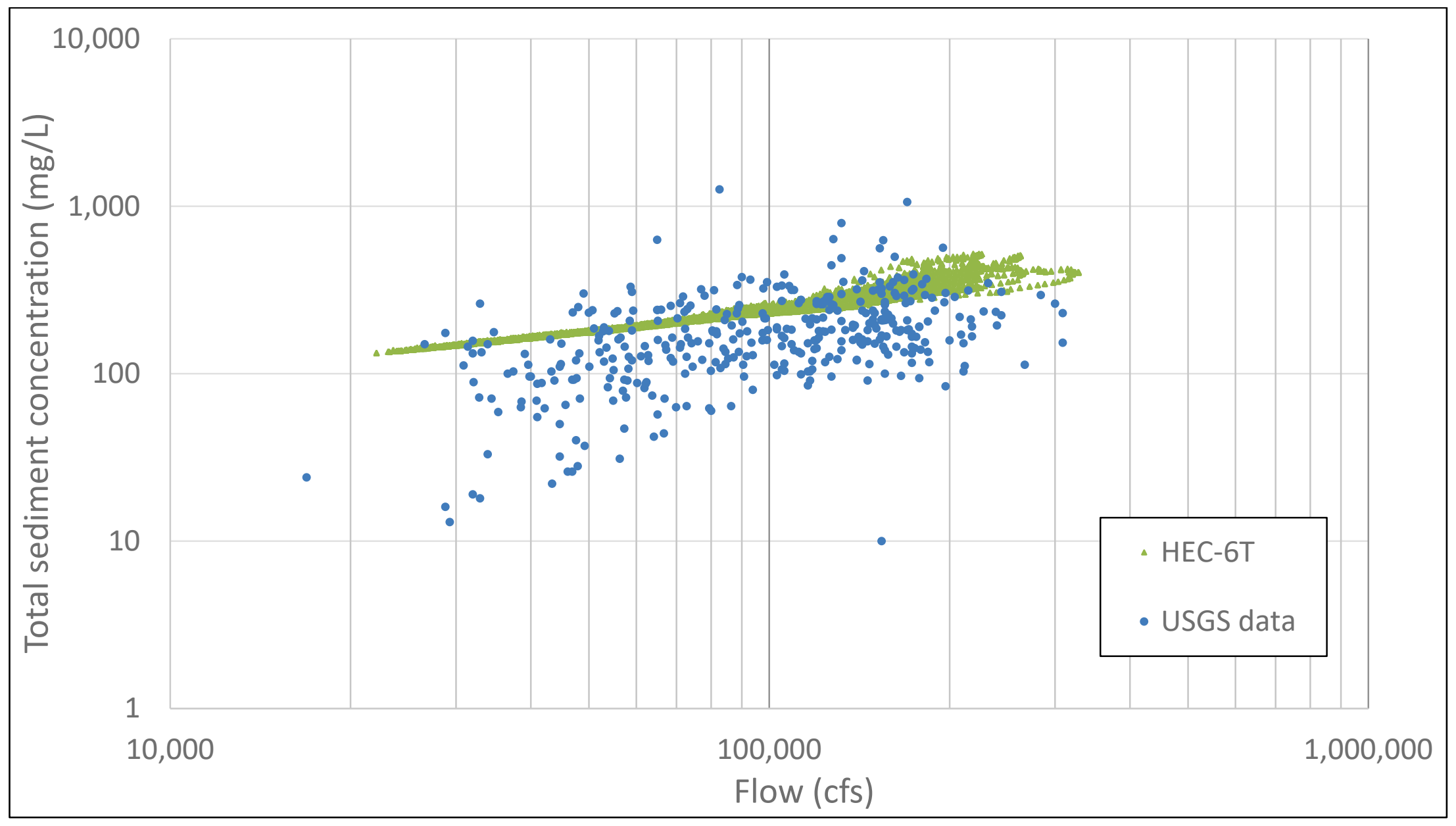


Figure 28. Coarse sediment concentrations for the Atchafalaya River at Mellville, LA, for 1997-2016.

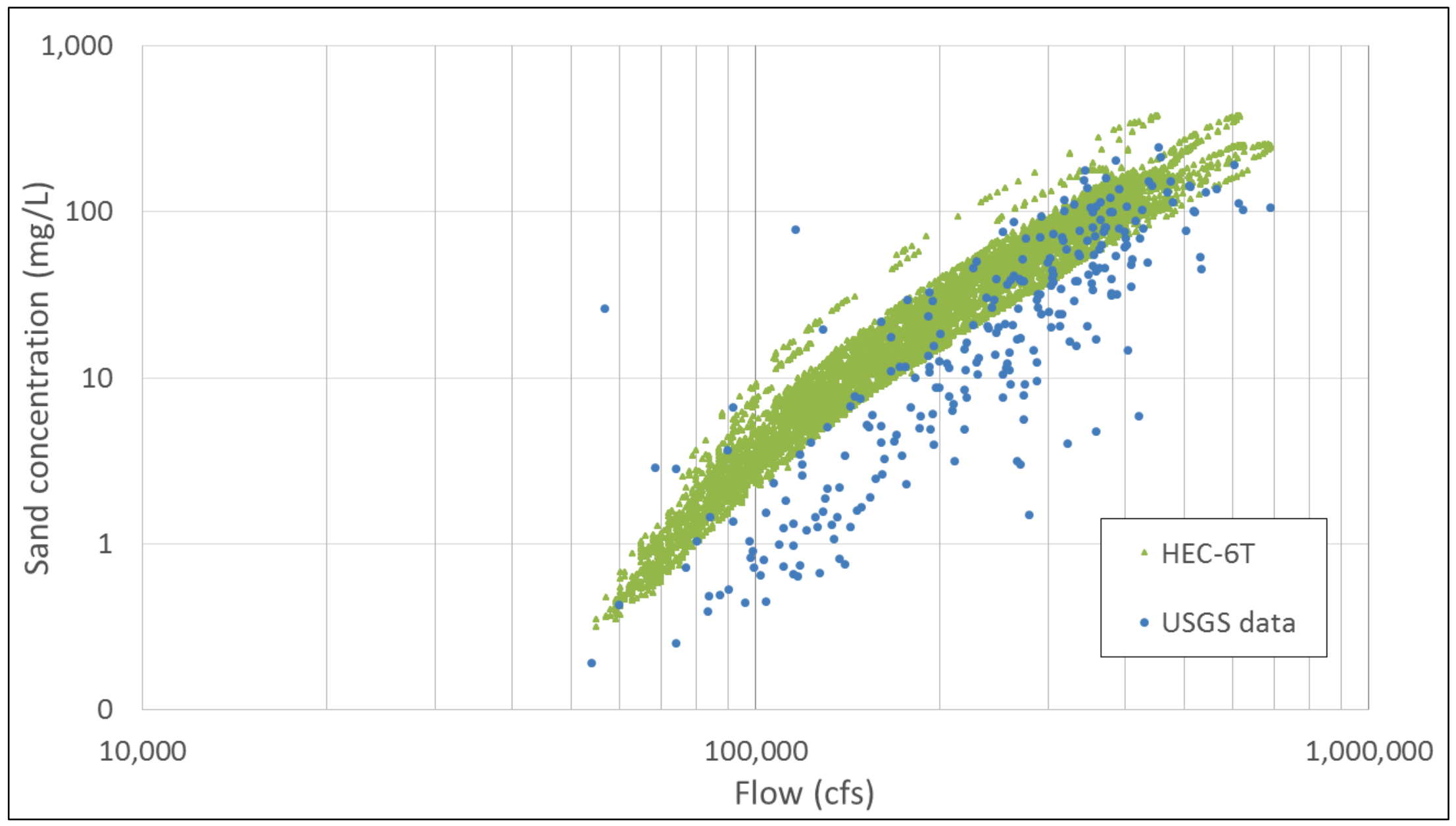


Figure 29. Total sediment concentrations for the Atchafalaya River at Mellville, LA, for 1997-2016.

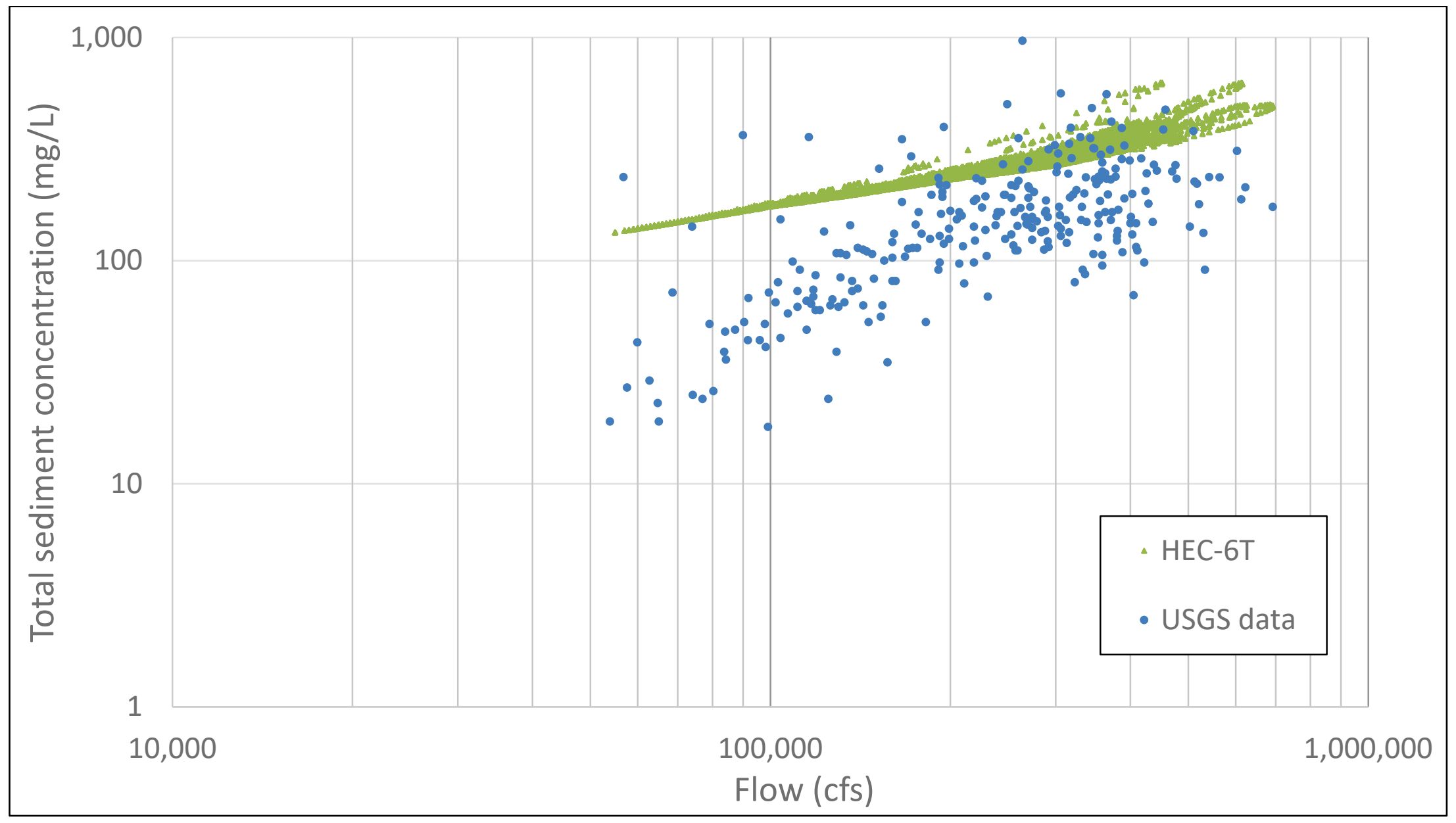


Figure 30. Coarse sediment concentrations for the Atchafalaya River at Simmesport, LA, for 1997-2016.

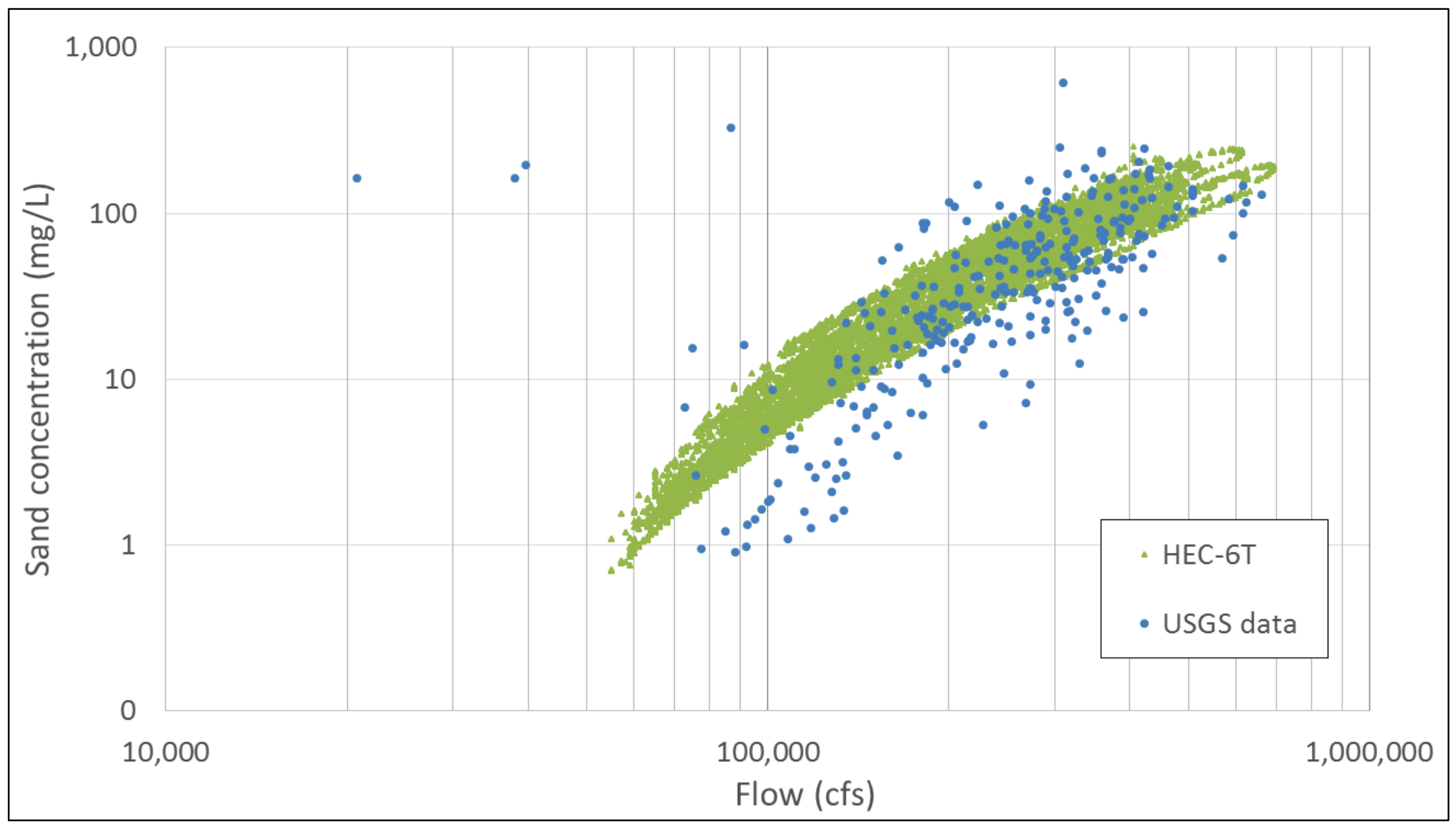


Figure 31. Total sediment concentrations for the Atchafalaya River at Simmesport, LA, for 1997-2016,

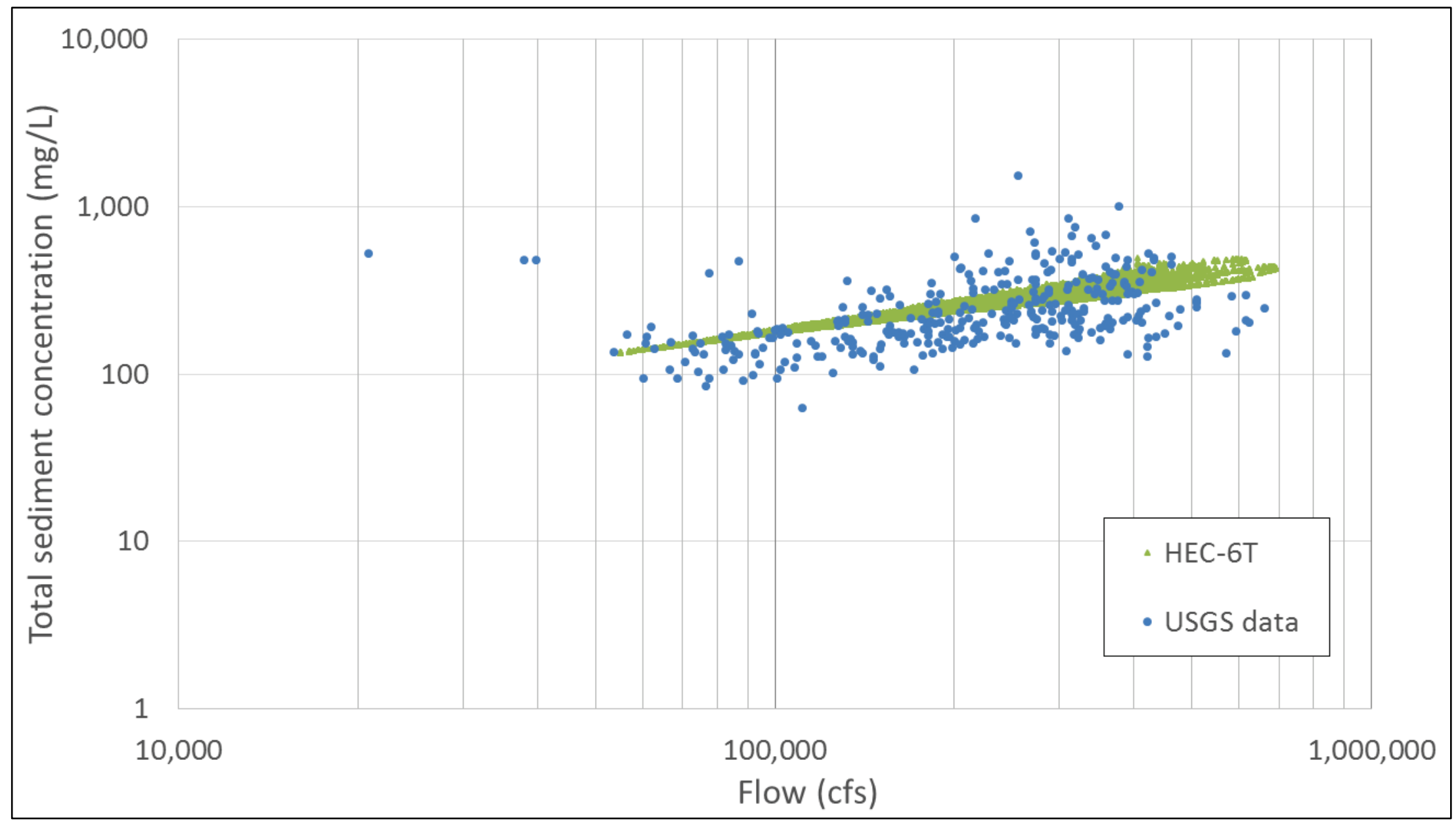


Figure 32. Comparison of computed and observed concentrations at Simmesport, LA.

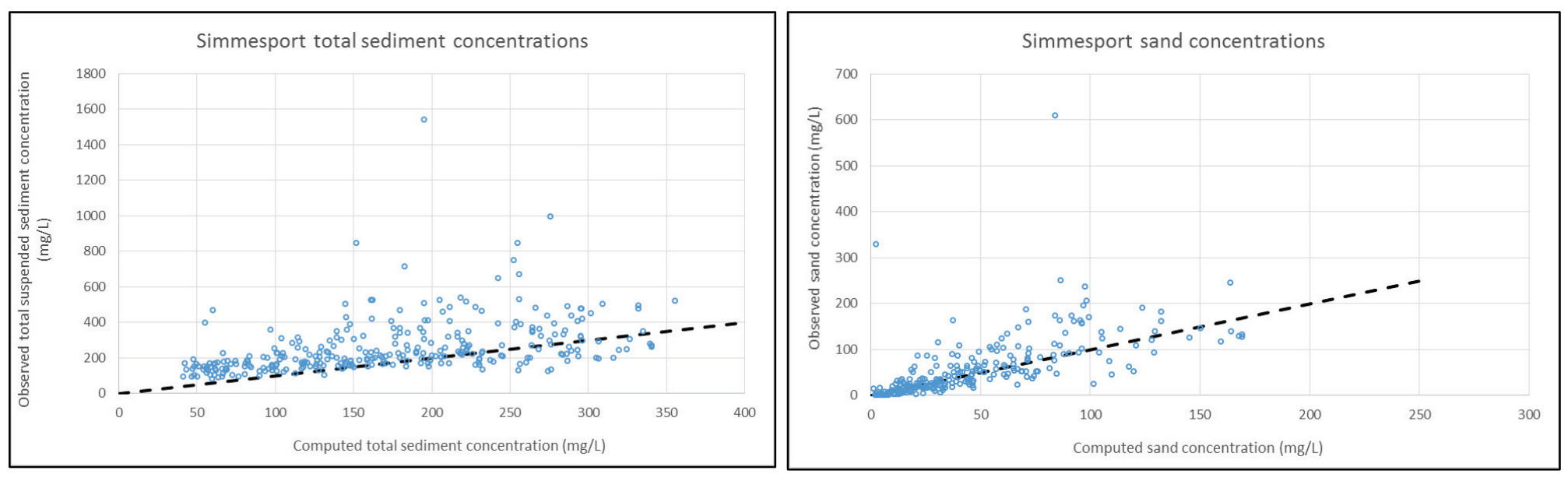

Figure 33. Comparison of computed and observed concentrations at Melville, LA.

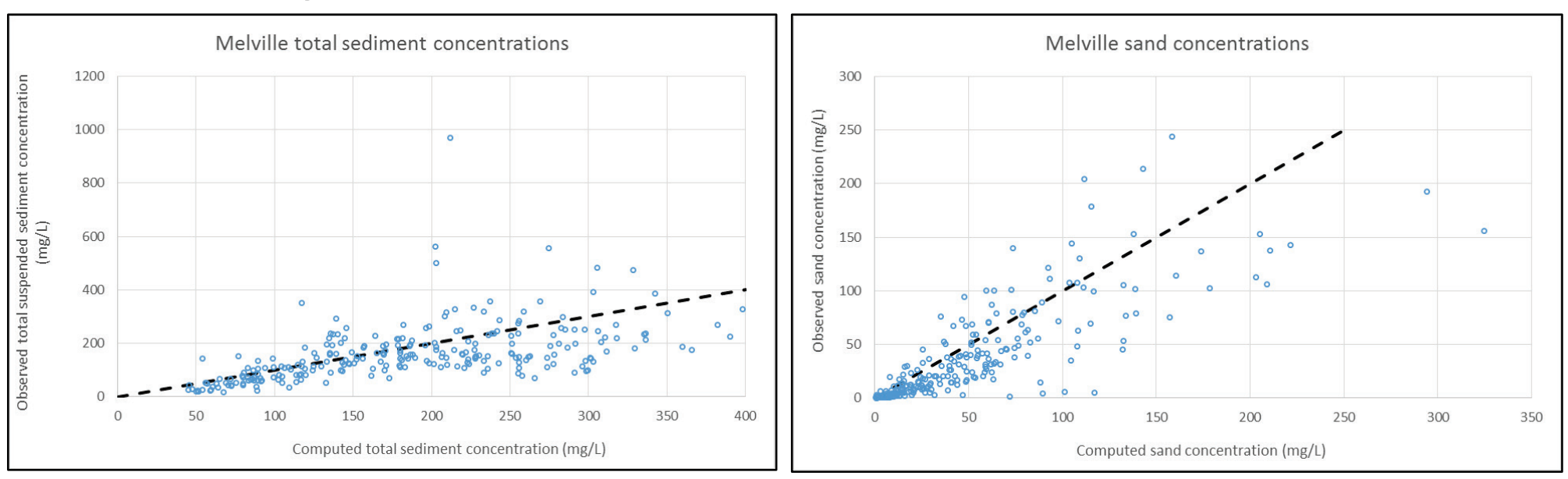


Figure 34. Comparison of computed and observed concentrations at Calumet, LA.
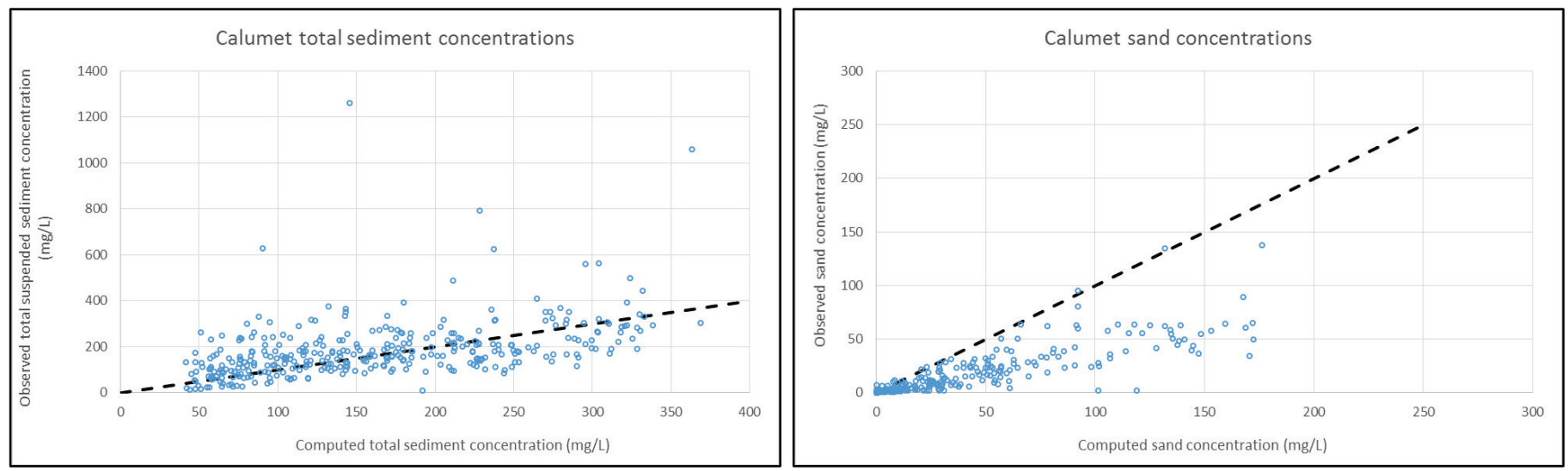

Figure 35. Comparison of computed and observed concentrations at Morgan City, LA.
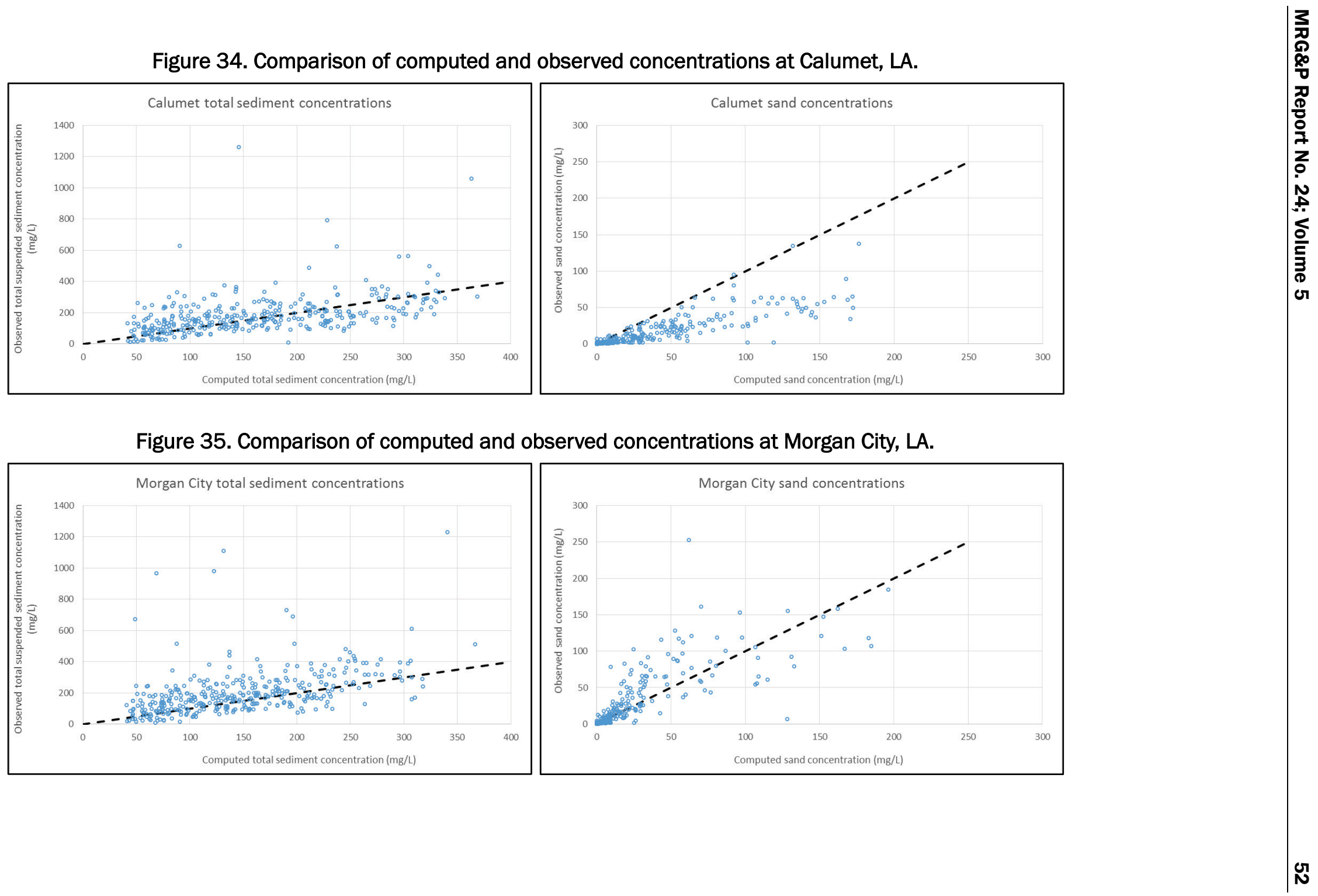
The survey data from 2010 can be compared with the HEC-6T calculated bed for 2010. Figure 36 through Figure 40 show the simulated and surveyed elevations within a few example cross sections where the 2010 survey data were available. The cross sections labeled HEC-6T 4/30/1997 reflect 1997 survey data. Overall, the trends of deposition or scour within the channel agreed with the survey results. Recent survey efforts from 2012 to 2016 by MVN have revealed some locations in the upper reach of the Atchafalaya River where bank failure has occurred. Figure 37 may show an example of that channel-widening process, which is not simulated in the HEC-6T model.

Figure 36. Comparison of bed elevations for cross section -4.77 in Segment 6 .

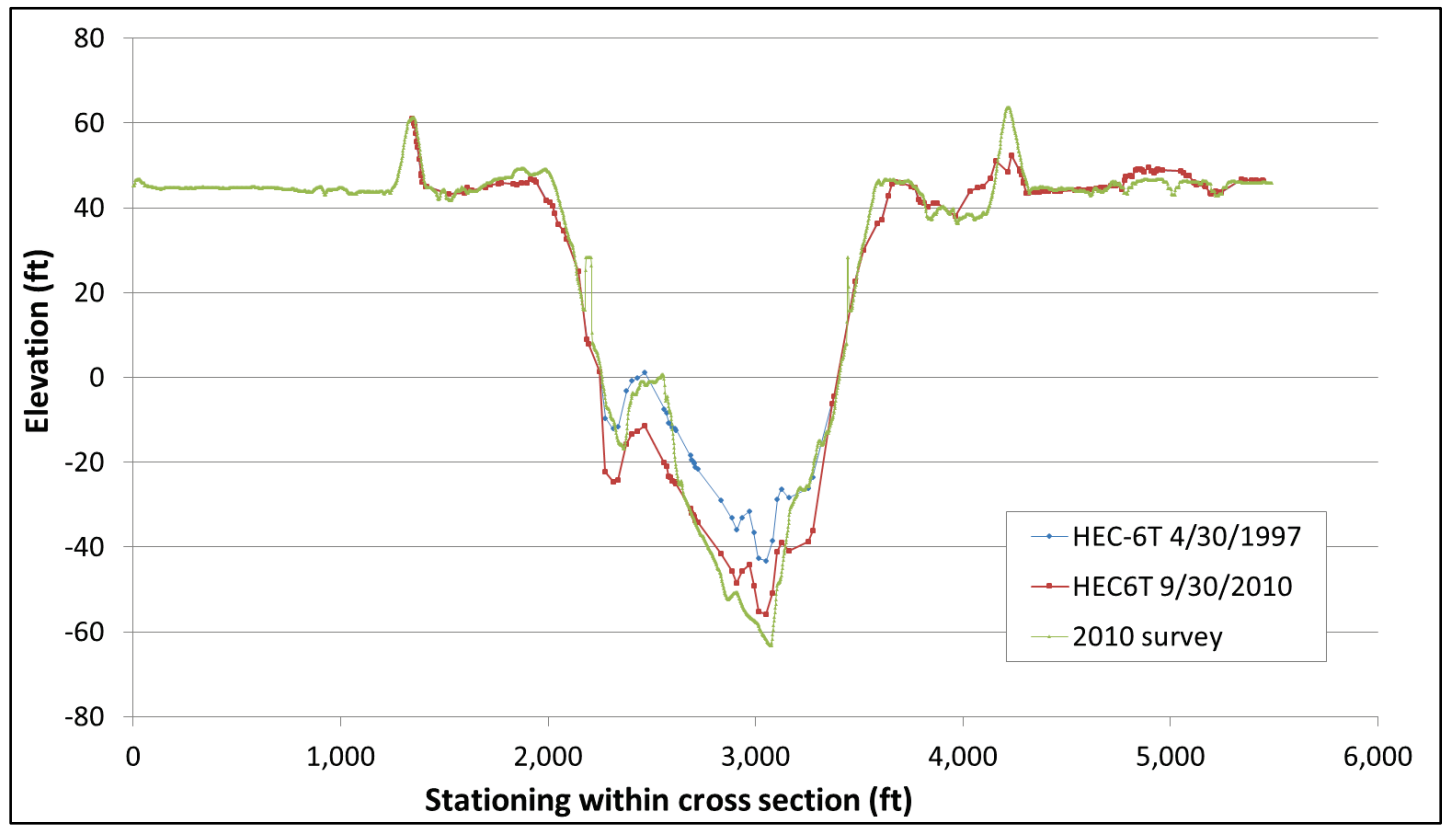


Figure 37. Comparison of bed elevations for cross section -35.7 in Segment 6.

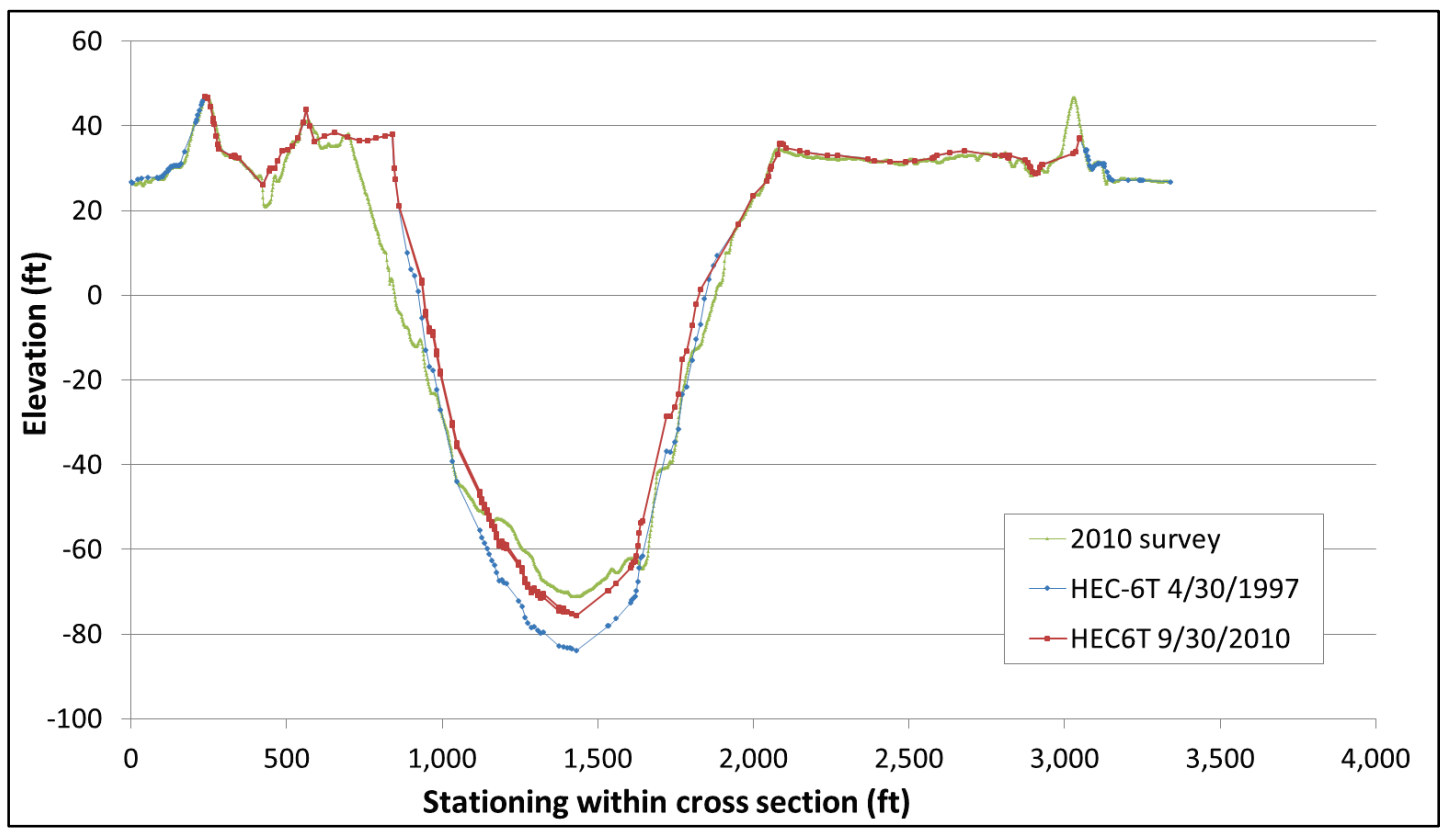

Figure 38. Comparison of bed elevations for cross section -66.1 in Segment 4.

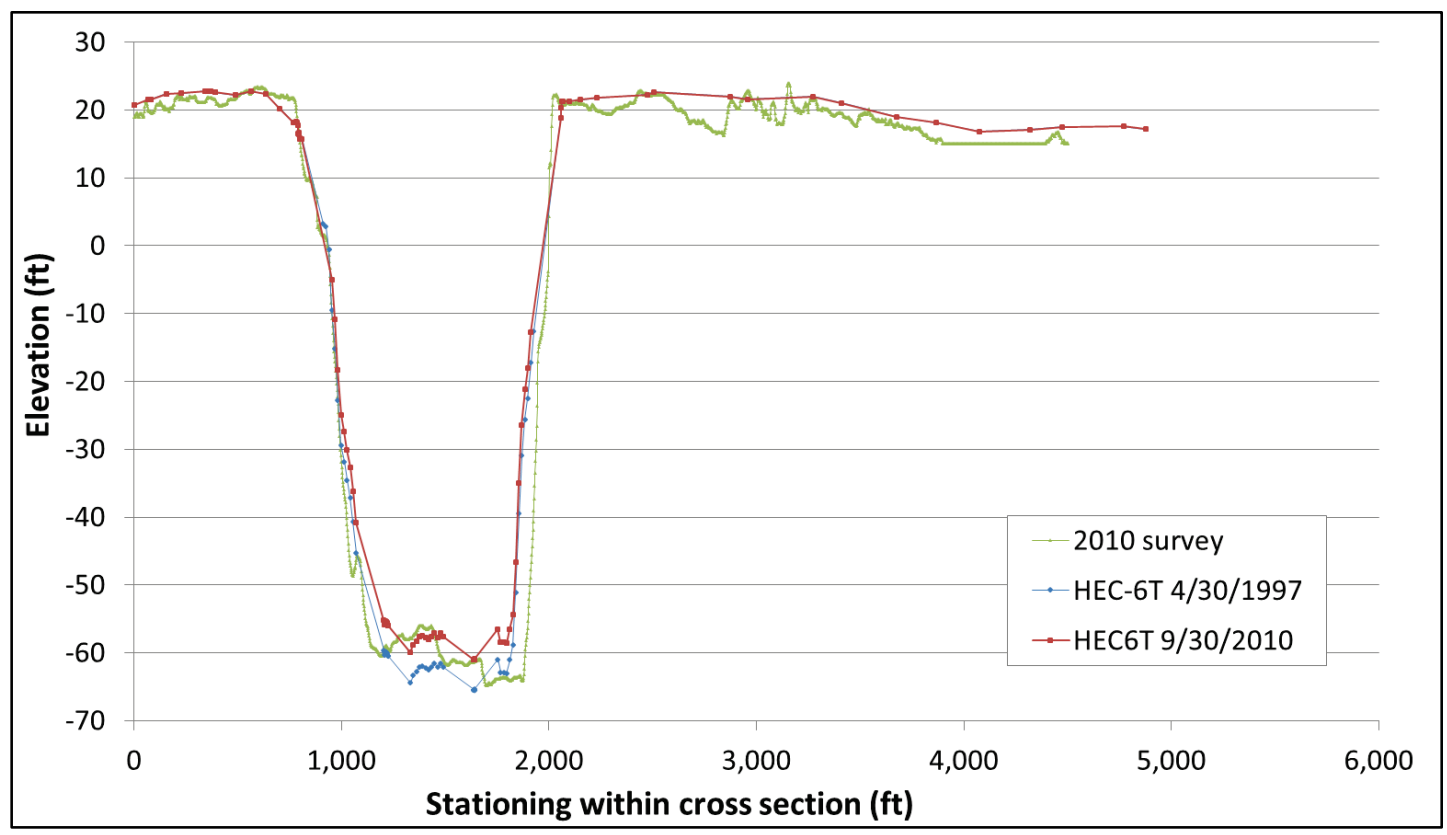


Figure 39. Comparison of bed elevations for cross section -89.7 in Segment 3.

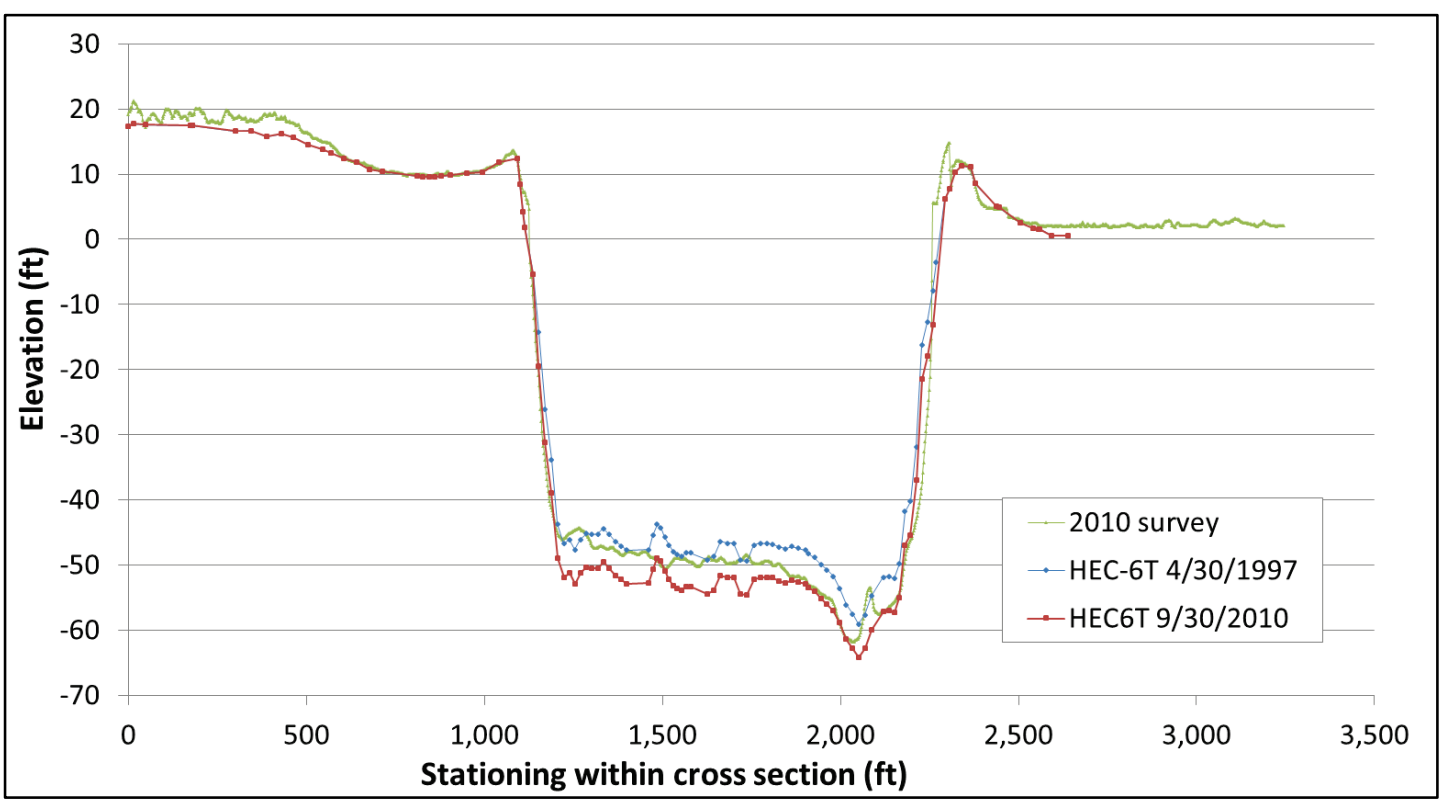

Figure 40. Comparison of bed elevations for cross section -104.0 in Segment 1.

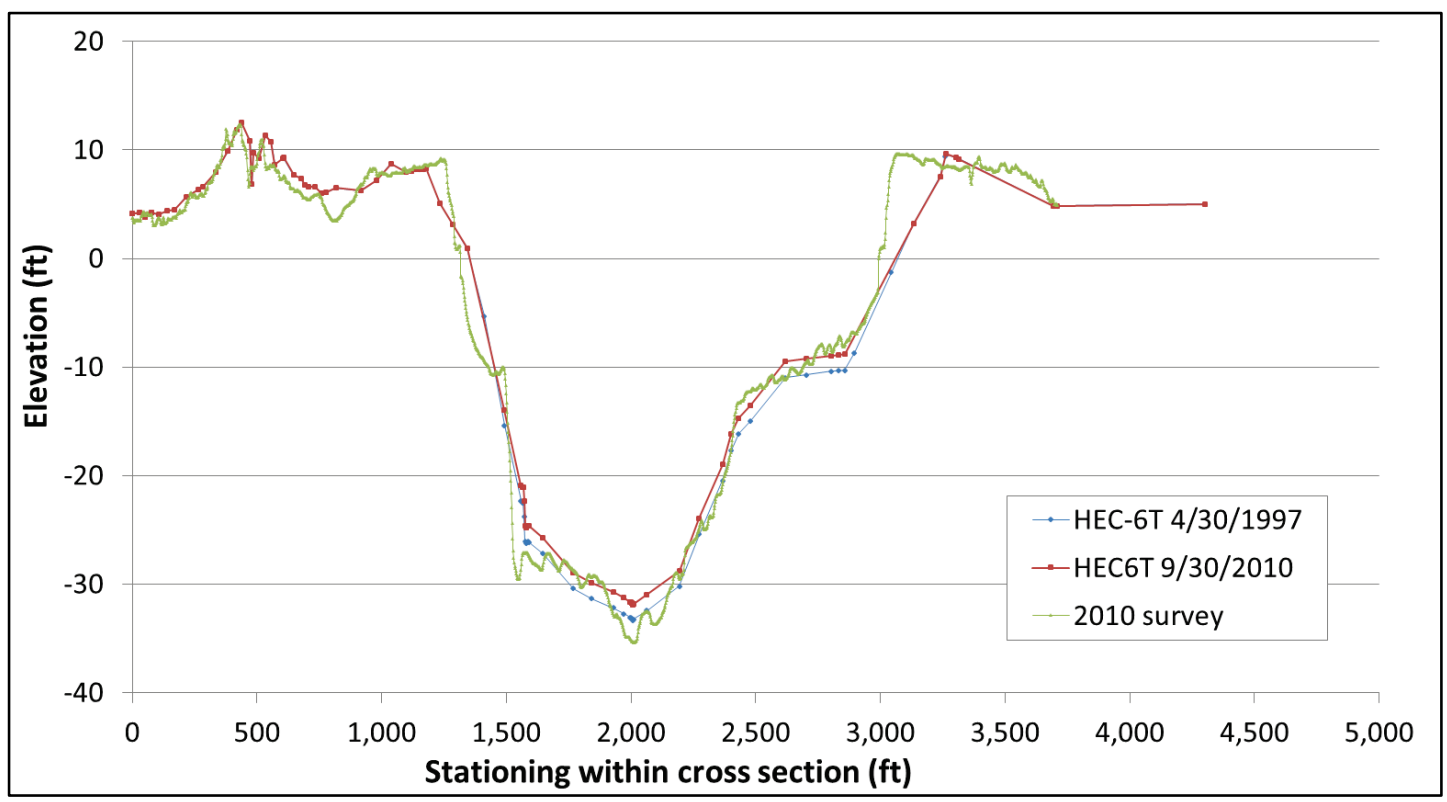




\section{Simulation of the future}

\subsection{Simulation setup}

\subsubsection{Upstream flow boundary condition}

The validated model was used to predict sedimentation changes 50 years into the future, from 2017 through 2066. Upstream flow data for 2017 through 2066 came from the recorded discharges at Simmesport. Since the distribution of flow through ORCC changed significantly in 1976, data prior to 1977 were not used. The time period 1977 to 2016 was used to simulate 2017 to 2056 . The remaining time period 2057 through 2066 used data from 2007 through 2016 to represent recent conditions as much as possible. Table 6 clarifies the dates of Simmesport recorded discharge used to simulate 50 years into the future. The only time there was flow through MCS during the time period used for inflows was 2011, so the attenuated 2011 MCS inflows, as discussed in Section 2.3.2, were used for those particular times.

Table 6. Data used for inflow boundary condition.

\begin{tabular}{|l|l|}
\hline Simulation Date & $\begin{array}{l}\text { Date of Data Source } \\
\text { (using Simmesport discharge) }\end{array}$ \\
\hline 1997 to 2016 & 1997 to 2016 \\
\hline 2017 to 2056 & 1977 to 2016 \\
\hline 2057 to 2066 & 2007 to 2016 \\
\hline
\end{tabular}

\subsubsection{Sea level rise}

Beginning 1 January 2017, the downstream water surface boundary condition used the intermediate sea level rise scenario from ER 1100-28162 (USACE 2013). The equation in the appendix of ER 1100-2-8162 is applied to each day after $31 \mathrm{Dec} 2016$ to calculate the downstream water surface using the recommended base year 1992. The Wax Lake Outlet kept the $0.3 \mathrm{ft}$ offset for a higher water surface at the downstream end of Segment 2, as discussed in Section 2.3.3 through the entire simulation.

\subsubsection{Subsidence}

Runs were performed with subsidence turned both on and off. Rates of subsidence were already present within the 2010 HEC-6T model. These 
rates varied spatially such that each cross section had a slightly different rate based on its location.

\subsubsection{Effects of the Project Design Flood (PDF)}

The primary objective of this effort was to determine the bed changes due to the 50 years of sedimentation. However, the bed is expected to also change during the hydrograph of the PDF event, so the bed could be significantly different at the peak of the event than before the event. To assess this impact, the peak flows of the PDF were simulated instantaneously without changing the bed between 30 Nov 2066 and 1 Dec 2066. The PDF used for this assessment was from the " $58 \mathrm{~A}-\mathrm{R}$ Authorized Yazoo" scenario in the Mississippi River HEC-RAS model, which begins December 1 and reaches a peak inflow to the Atchafalaya River on March 8. The PDF event daily flows were implemented in the HEC-6T model from 1 Dec 2066 through 8 March 2067.

A separate simulation was also performed to assess the changes caused by the PDF event with the 2010 conditions. For this simulation, the PDF peak flows were simulated instantaneously between 30 Nov 2010 and 1 Dec 2010, and then the PDF event was simulated from 1 Dec 2010 through 8 Mar 2011.

For comparison purposes, the 2011 event was also simulated separately to determine the effects of bed changes during the rise of the 2011 event. For that event, the 2011 peak flows were simulated instantaneously between 30 Sep 2010 and 1 Oct 2010, and then the 2011 event was simulated until it reached the peak flows.

\subsection{Results}

\subsubsection{Wax Lake Outlet}

Wax Lake Outlet is an artificial distributary of the Atchafalaya River. The distributary junction is located at Atchafalaya RM -100 (1963) where Grand Lake intersects the river. Shaw et al. (2013) provided the following description of the Wax Lake Outlet/Lower Atchafalaya River bifurcation:

A 13 to 21m deep channel connects the upstream and downstream Atchafalaya River, and hosts sand dunes. The southwest side of the Atchafalaya River and the entrance to the Grand Lake Reach 
is shallow (4-7m) and is composed entirely of exposed bedrock. A steep scarp exists between the deep Atchafalaya River and the shallow Grand Lake Reach (4-67\% slope). The 200m wide ramp extending toward the Grand Lake Reach was initiated by dredging and hosts some sand dunes. This ramp is the only gradual transition from the sand-rich thalweg and the shallow Grand Lake Reach.

After flowing approximately 8 miles through Grand Lake, diverted flows enter the Wax Lake Outlet, which was dredged in 1941 and connects Grand Lake to Wax Lake in the Atchafalaya Bay. The Wax Lake Outlet was designed to lower flood stages at Morgan City, which is located on the Lower Atchafalaya River approximately 20 miles downstream from the distributary junction.

The beds of both Grand Lake and the dredged outlet channel consist of erosion resistant clay materials. Shaw et al. (2013) characterized the bed of Grand Lake and the Wax Lake Outlet as bed rock because the bed "is a relict deposit that precedes and is not associated with the sediment transport system, and is a cohesive, exposed surface covered by erosional bed forms and tool marks demonstrating that the material is resistant to erosion." Although erosion resistant, the bed is still subject to scour. Shaw et al. (2013) determined that between 1942 and 1964 the upstream 5-mile reach of the dredged channel experienced an average erosion rate of $0.92 \mathrm{ft} /$ year. Between 1964 and 2006, the average erosion rate in this reach decreased to $0.31 \mathrm{ft} /$ year. The next 8 miles of the dredged channel had an average erosion rate of $0.15 \mathrm{ft} /$ year between 1942 and 1964, increasing to $0.30 \mathrm{ft} /$ year between 1964 and 2006. Shaw et al. (2013) determined that the Grand Lake reach eroded at a rate of $0.12 \mathrm{ft} /$ year between 1964 and 2006. Data were insufficient to determine a rate for 1942-1964.

Due to the bed erosion in the Wax Lake Outlet, the percent of the Atchafalaya River flows diverted has increased. Powell (1996) reported that the Wax Lake Outlet was designed in 1941 to divert 20\% of the Atchafalaya River discharge, but by 1988 that percentage had increased to $42 \%$. A weir was installed in 1988 to direct more discharge down the Lower Atchafalaya River because it had been aggrading. The weir decreased the Wax Lake Outlet diversion to 30\%. However, it was removed in 1994 because stages at Morgan City increased by 
approximately $1 \mathrm{ft}$. (Powell 1996). Mossa (2016) reported that the flow down the Wax Lake Outlet is now (2016) equivalent to the flow down the Lower Atchafalaya River.

In this study, channel bed elevations in Grand Lake and in the Wax Lake Outlet upstream from the Gulf Intracoastal Waterway were treated as non-erodible. Cross sections in these reaches were assigned a bed sediment reservoir depth of $0.1 \mathrm{ft}$., which effectively prevents erosion below 1997 bed elevations. However, sediment deposited at any cross section could be eroded later in the simulation. Downstream from the GIWW, erosion was allowed. Bed sediment reservoir thicknesses in this reach were set between 4 and $18 \mathrm{ft}$. This assignment of bed sediment reservoir depths produced the most realistic simulation of channel bed elevation changes during the calibration period between 1997 and 2010. Model results could be improved if erosion rates were determined for the cohesive beds in Wax Lake and Grand Lake and then incorporated into the numerical model. This would require a bed sampling collection and analysis program.

The progression of Wax Lake Outlet diversion percentages with time, calculated by HEC-6T, is shown in Figure 41. The percentages of discharge upstream from the bifurcation that flow down the Wax Lake Outlet at Calumet and down the Lower Atchafalaya River at Morgan City at discharges of 300,000 cfs and 615,000 cfs were compared. The amount 300,000 cfs represents a bankfull discharge at Simmesport, and 615,000 cfs was the peak of the January 2016 flood at Simmesport and was chosen to represent a flood discharge. Bankfull discharge is the maximum discharge that can be contained within the channel without over-topping the banks. The figure shows a decreasing trend in flow percentage down the Lower Atchafalaya River. The percentage of the bankfull flow diverted to Morgan City is predicted to decrease from $54 \%$ to $30 \%$ over the next 50 years (2016-2066). The percentage of flood flow diverted to Morgan City is predicted to decrease from $57 \%$ to $46 \%$ over the next 50 years. The numerical simulation also calculated significant aggradation in the Lower Atchafalaya River during this same time period. Note that the simulated results do not account for probable scour in the Wax Lake Outlet. The calculated increase in flow percentage down the Outlet in the numerical model is primarily due to reduced conveyance capacity in the Lower Atchafalaya. 
A test was conducted with the numerical model to estimate the effect of potential scour in the Wax Lake Outlet on the flow diversion percentages at the Wax Lake Outlet bifurcation. In the test, restrictions on channel erosion in Grand Lake, the dredged outlet channel, and the Wax Lake delta were removed so that the channel bed was treated as fully alluvial. This assignment of bed sediment reservoir depth is considered unreasonable and was calculated only for comparison purposes. The progression of Wax Lake Outlet diversion percentages with time, calculated by HEC-6T, is shown in Figure 42 . Figure 42 shows a decrease in flow down the Lower Atchafalaya River in both the simulation period between 1997 and 2016 and for the next 50 years. The percentage of the bankfull flow diverted to Morgan City would be predicted to decrease from $47 \%$ to $15 \%$ over the next 50 years. The percentage of flood flows diverted to Morgan City would be predicted to decrease from $54 \%$ to $33 \%$ over the next 50 years.

The numerical model also calculated significant aggradation in the Lower Atchafalaya River during this 2010 to 2066 time period for both the adopted bed condition and the fully alluvial bed condition. Calculated average bed changes between 2010 and 2066 for the adopted bed erosion limits and the test with no limit on bed erosion are compared in Figure 43. In the Wax Lake Outlet (Segment 2) in the vicinity of RM -110 significant scour is shown in Figure 43 for the adopted bed conditions. Even though a fixed bed was assigned in this reach for the 1997 initial geometry, deposition occurred between 1997 and 2010. It is this deposited material that erodes as the simulation progresses. The figure shows a long-term aggradation trend for the Lower Atchafalaya and a long-term degradation trend in Wax Lake Outlet. The existing clay bed in the Wax Lake Outlet is preventing a much more severe degradation trend. 
Figure 41. Changes in discharge percentages at Calumet and Morgan City. (Calculated between 1997 and 2066 for a bankfull discharge and a flood discharge. Discharge magnitudes are from Simmesport.)

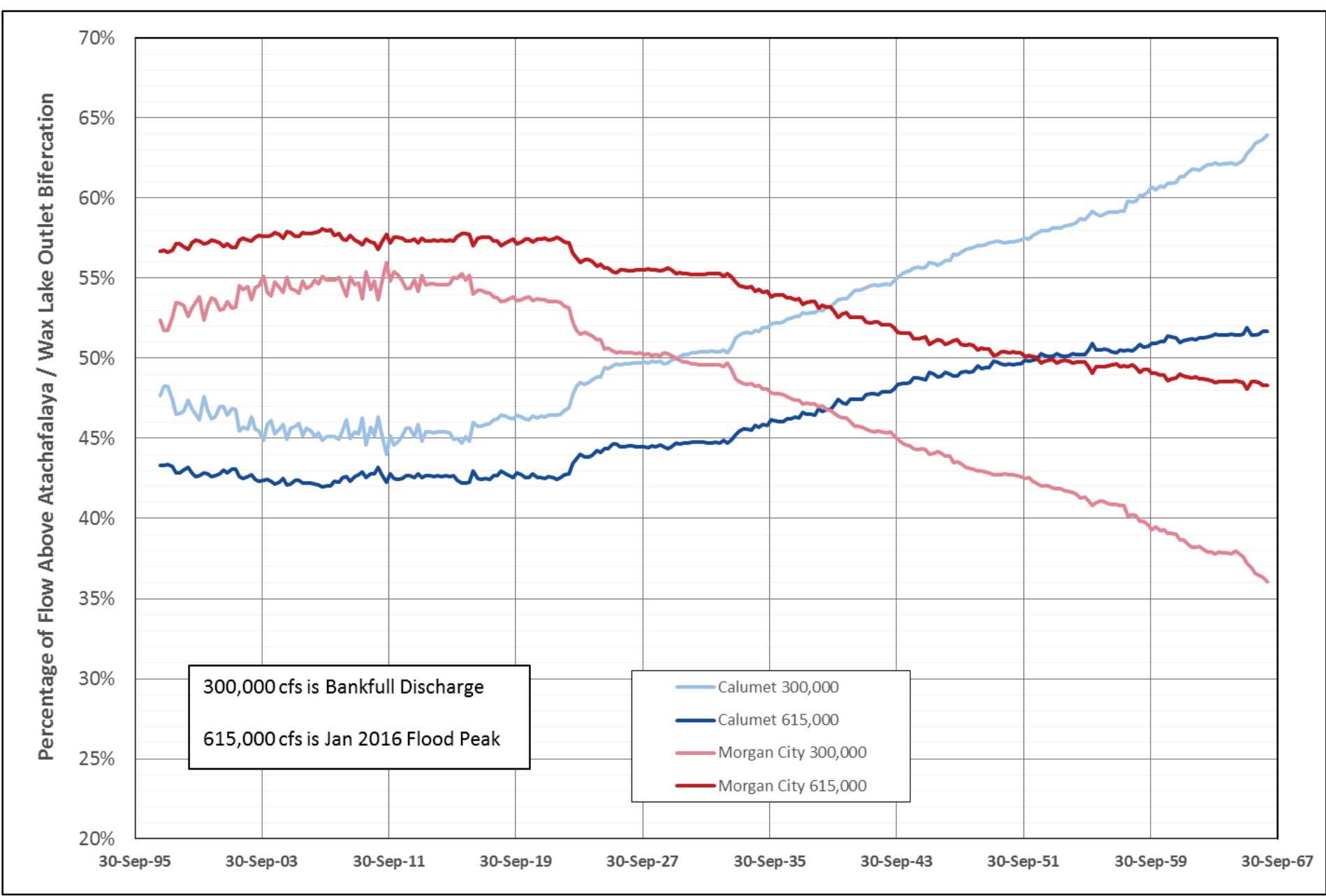


Figure 42. Changes in discharge percentages at Calumet and Morgan City with no limitation on bed erosion. (Calculated between 1997 and 2066 for a bankfull discharge and a flood discharge. Discharge magnitudes are from Simmesport.)

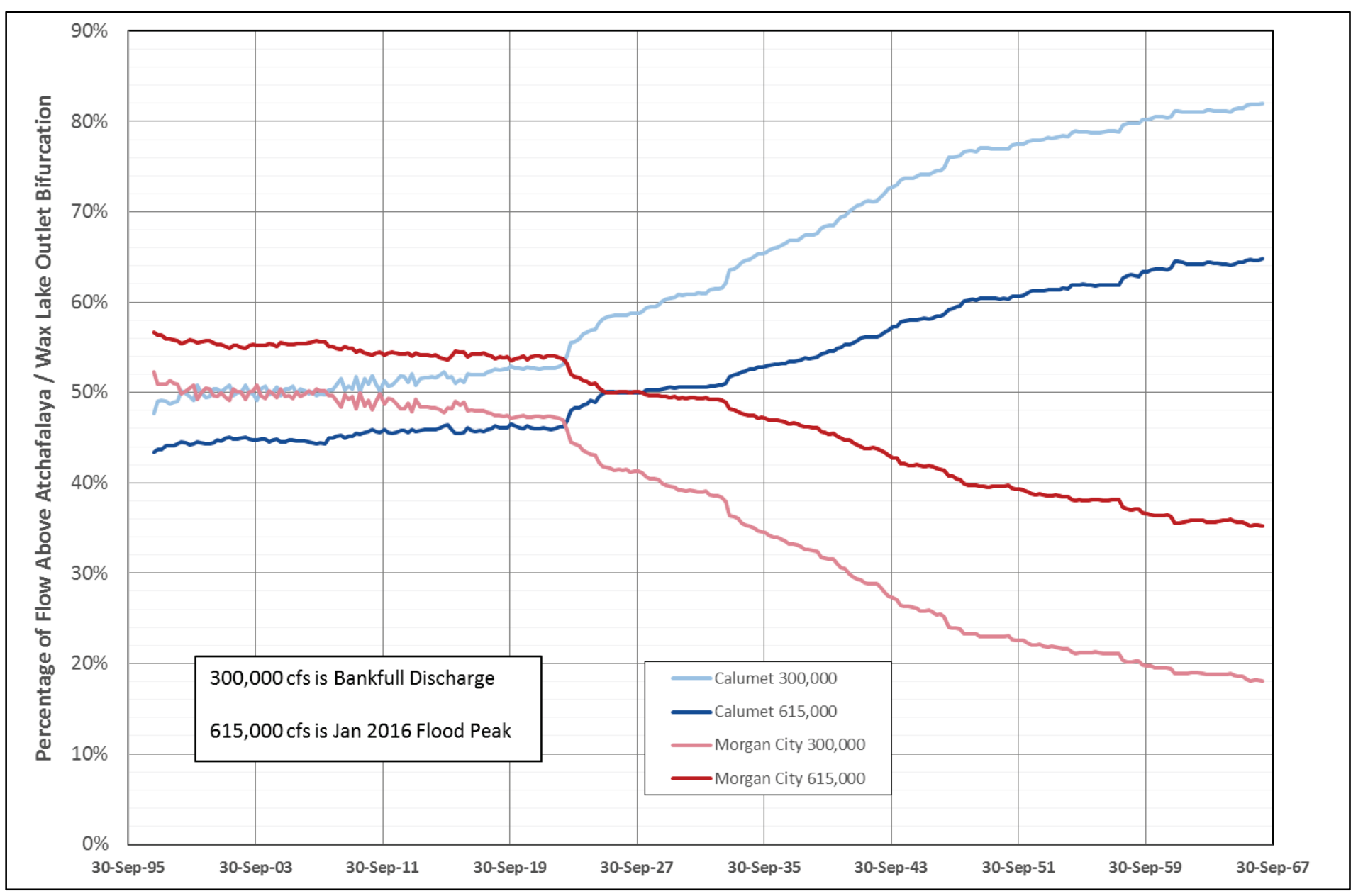


Figure 43. Calculated average bed change 2010-2066 showing the effect of limiting erosion potential in the Wax Lake Outlet.

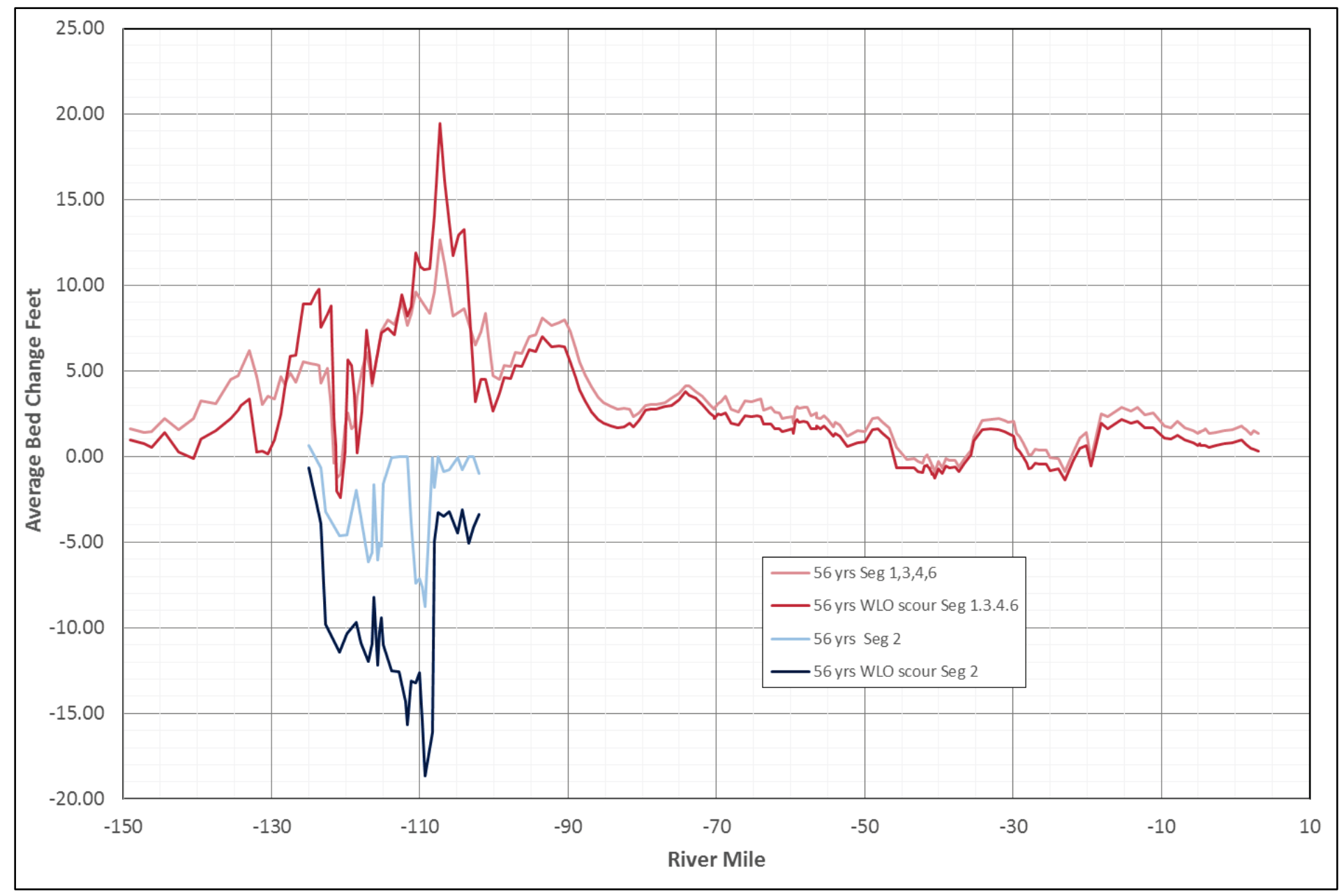




\subsubsection{Bed changes during the rise of the PDF}

Figure 44 shows the effects on peak water surfaces of the bed changes during the rise of the PDF event. The figure includes segments 1, 3, 4, and 6, and does not include the parallel segments 2 and 5, for clarity. The calculated sedimentation effects during the rise of the PDF hydrograph are demonstrated by comparing the calculated PDF instantaneous and PDF hydrograph profiles. This can be done using both the 2010 and 2066 profiles (the two red or the two blue lines in Figure 44). The change from the dotted line to the solid line shows that during the rise of the PDF, hydrograph sedimentation effects cause a significant decline in the water surface elevations. This is due to channel degradation in the constricted Morgan City reach (vicinity of RM -120). Accounting for sedimentation effects during the rise of the PDF hydrograph results in a water surface difference of approximately $6 \mathrm{ft}$ upstream from RM -120, transitioning to approximately $3 \mathrm{ft}$ at $\mathrm{RM}-55$, and approximately $2 \mathrm{ft}$ between RMs -55 and 0 . The average channel bed change shows scouring of over $20 \mathrm{ft}$ in cross sections immediately downstream of Morgan City. Mossa (2016) documented changes of the same magnitude during the 1973 event. From Figure 22 of Mossa (2016), mean bed changes of approximately 6 meters $(\mathrm{m})$, and thalweg changes of approximately $7 \mathrm{~m}$, during the 1973 flood were reported. 
Figure 44. Effects of the bed changes during the rise of the PDF event on the peak water surfaces.

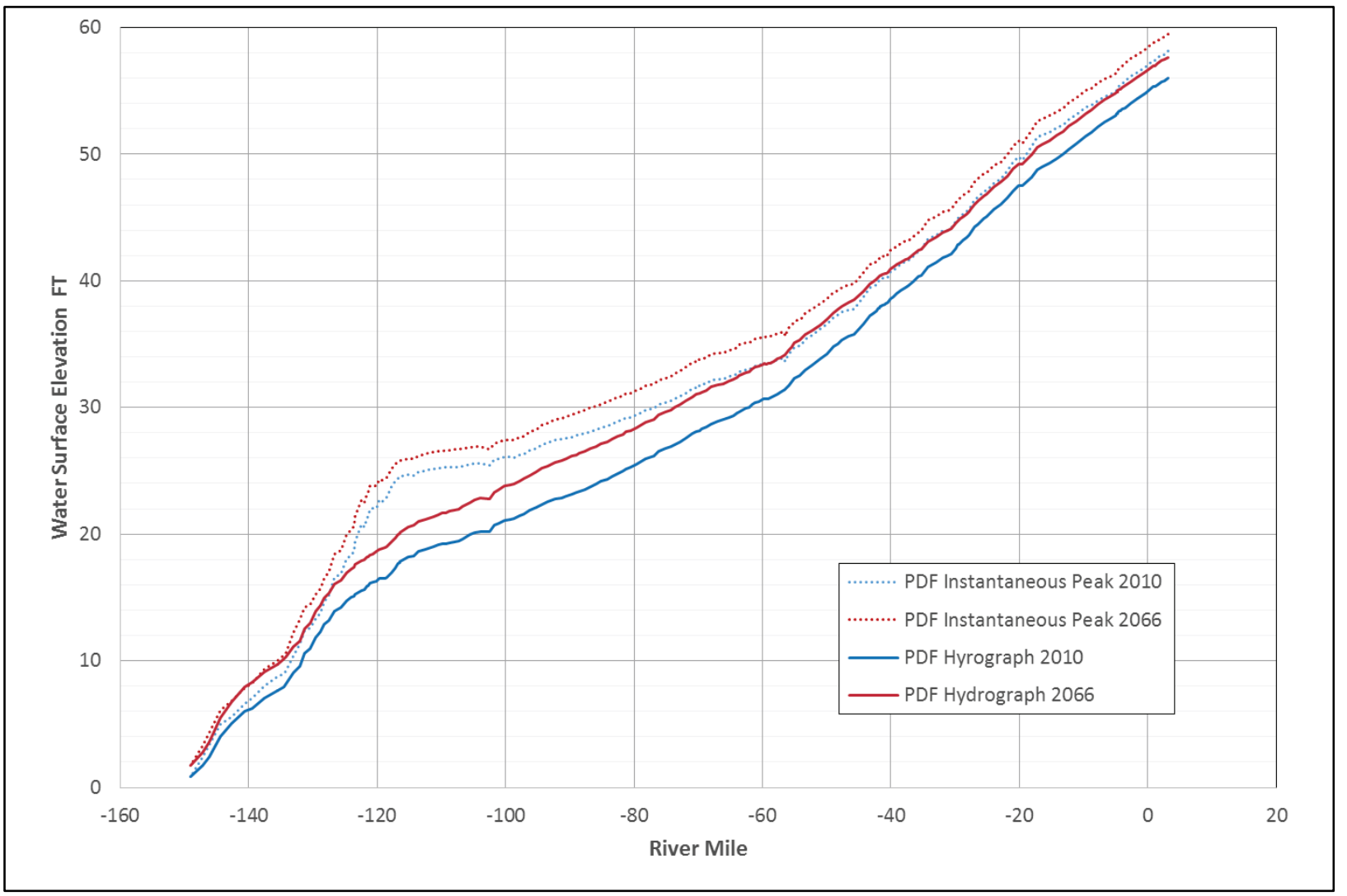

Calculated water surface elevation differences in Wax Lake Outlet for peak PDF water surface elevations are shown in Figure 45. The long-term effects of sedimentation on PDF water surface elevations are similar in the reach downstream from the bifurcation in both the Wax Lake Outlet and the Lower Atchafalaya River. There is only a minor degradation in the Wax Lake Outlet due to the PDF, specifically $-2.5 \mathrm{ft}$ at RM -125 and $-1 \mathrm{ft}$ at RM -122.7 and -123.3. The large amount of scour near Morgan City causes the flow at Calumet to decrease from 665,000 cfs for the instantaneous peak to $595,000 \mathrm{cfs}$ with the hydrograph, approximately an $11 \%$ decrease in the peak flow. 
Figure 45. PDF water surface elevations of the Atchafalaya River main channel and Wax Lake Outlet.

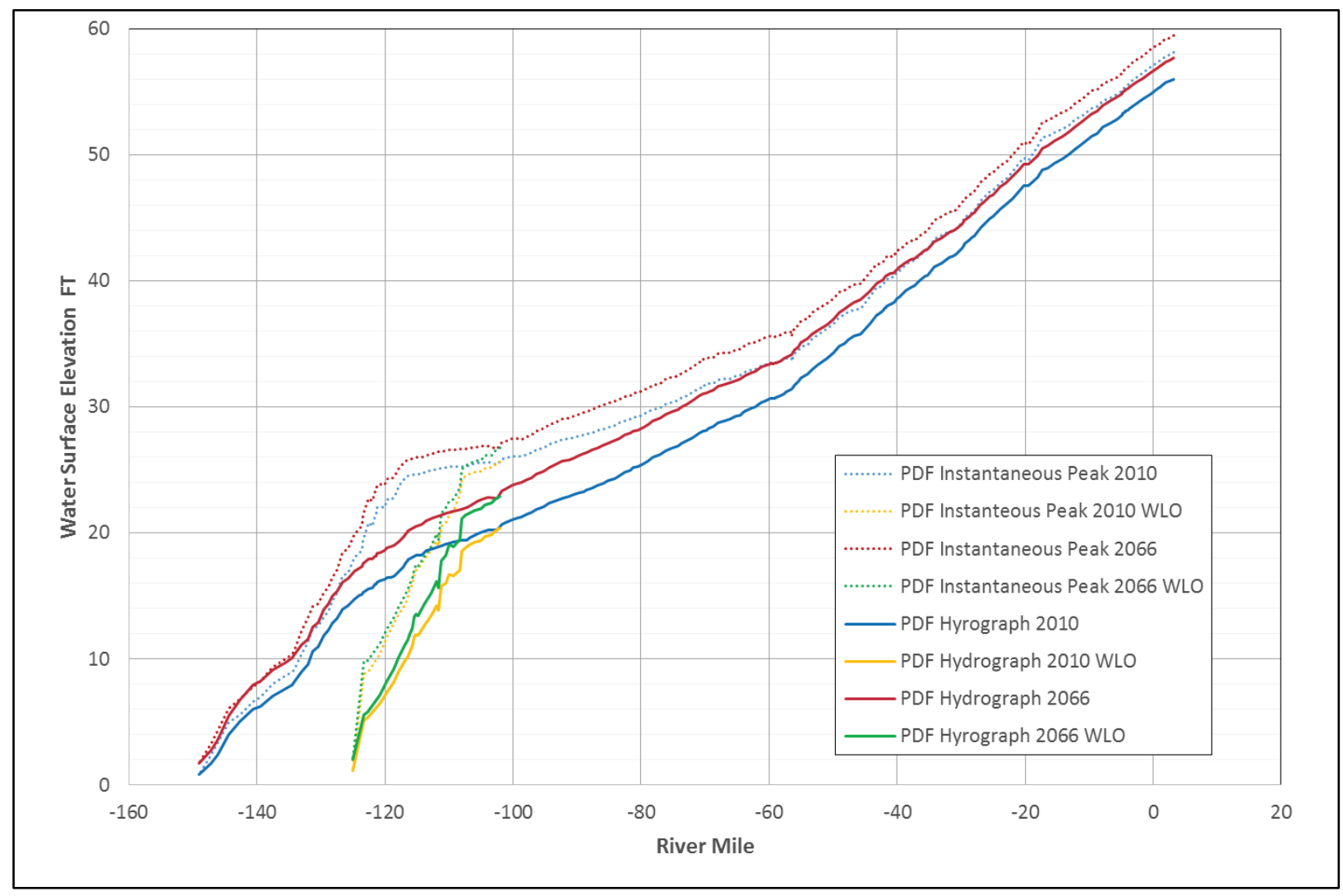

Bed changes during the 2011 flood had a much smaller impact on the water surfaces, as shown by the difference between the solid brown and dotted brown lines in Figure 46. This indicates that a fixed-bed hydraulic model is acceptable for simulating the 2011 event. However, the PDF event (scenario 58A-R Authorized Yazoo) appears to exhibit much different behavior than 2011. The PDF hydrograph imposes an extreme nonequilibrium condition onto the Atchafalaya River system below the Wax Lake Outlet bifurcation. All of the East Atchafalaya Floodway flow rejoins the river at this location. The MCS accounts for approximately $40 \%$ of the combined PDF flow past Calumet and Morgan City, and most of the MCS flow goes into the Atchafalaya River downstream from the bifurcation. During the 2011 event, the peak flow through MCS was $170,000 \mathrm{cfs}$, and it was above $160,000 \mathrm{cfs}$ for 11 days (Table 10 of Maynord [2014]). The flow through MCS during the PDF reaches 600,000 cfs, and it remains at $600,000 \mathrm{cfs}$ for 31 days. Also, the peak flow at Simmesport during 2011 was 692,000 cfs whereas the peak flow during the PDF at Simmesport would be 873,000 cfs. Sand concentrations in the Morganza inflow are negligible. As a result, the bed material concentrations are 
significantly less than equilibrium in the Atchafalaya River at Morgan City, and degradation potential is extreme during the PDF.

Figure 46. Calculated peak water surface profiles for the PDF and the 2011 flood.

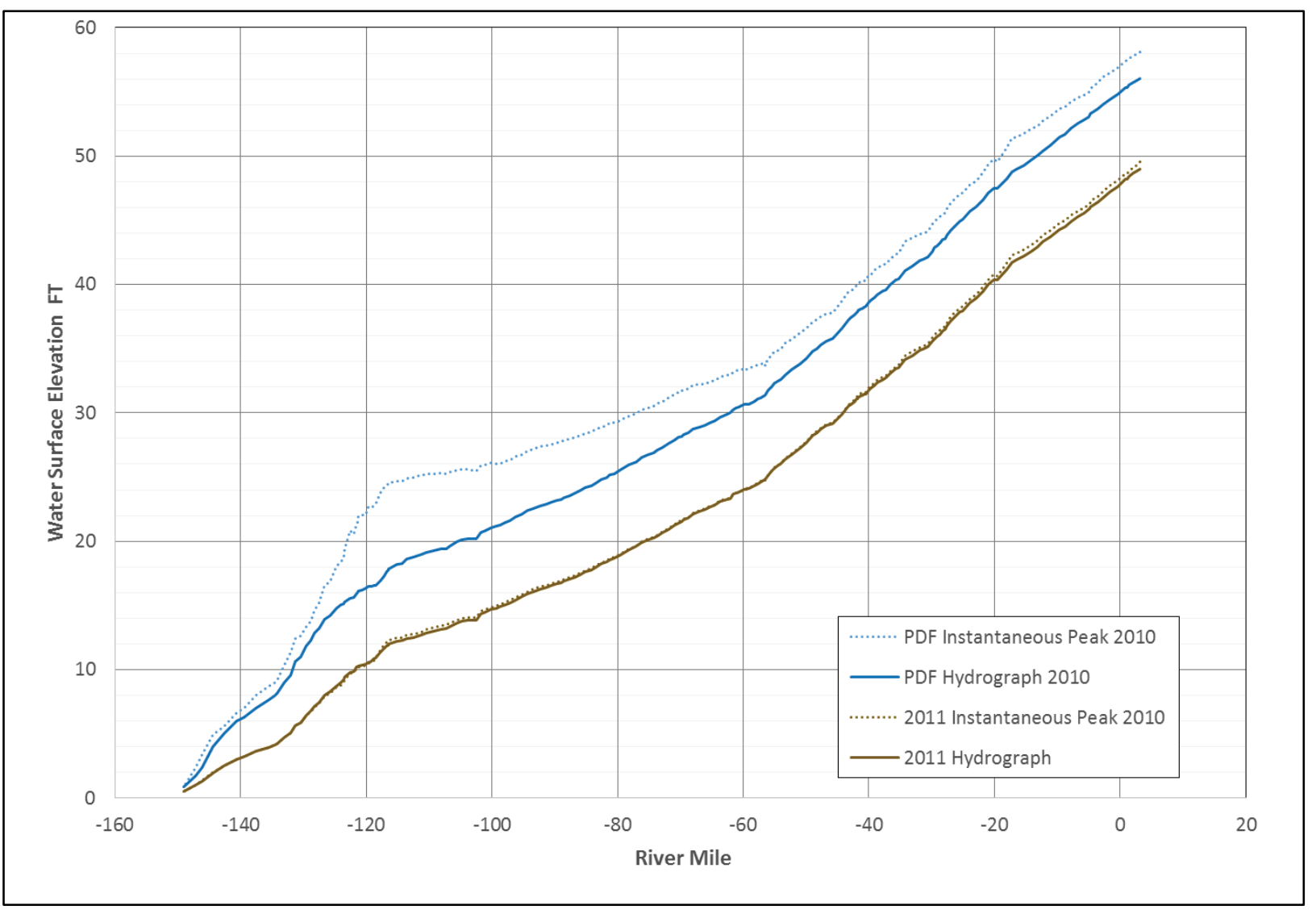

\subsubsection{Mean bed changes}

The average bed changes for the 50-year simulation, from 2010 conditions to 2066 conditions, is shown in Figure 43 by the light-blue and light-red lines. The long-term sedimentation effects are demonstrated by comparing the calculated water surface profiles for 2010 and 2066 in Figure 45. This comparison can be made using both the PDF Instantaneous Peak 2010 and PDF Instantaneous Peak 2066 profiles and the PDF Hydrograph 2010 and PDF Hydrograph 2066 profiles (the two dotted lines and the two solid lines in Figure 45). The calculations predict that after 56 years, sedimentation effects would result in higher PDF water surface elevations of approximately 2 to $3 \mathrm{ft}$. 


\subsubsection{Specific gage comparisons}

Specific gage plots based on historical stage and discharge data have been used extensively to document trends in water surface elevations at gage locations. Specific gage analyses provide important perspectives relative to past river behavior at a specific location, but trends cannot be extrapolated to predict future conditions. Specific gage analysis incorporates all the morphological factors influencing stage and cannot be used to identify the effect of an individual variable.

The advantage of a numerical model is that it can be used to predict future trends in water surface elevations and it can be used to predict both past and future trends between gages. The reliability of the model's prediction is predicated upon the model's ability to simulate the significant geomorphic processes that influence long-term change in stage. The HEC-6T numerical model accounts for future aggradation and degradation of the river bed but does not account for possible future changes in bed roughness, floodplain roughness, or change in channel shape due to meandering. There is also uncertainty associated with future changes in the boundary conditions, such as sediment inflow. Confidence in numerical model prediction is enhanced when historical changes in specific gage are correctly reproduced by the model. This success implies that the most significant geomorphic processes have been accounted for in the numerical simulations.

Figure 47 shows the calculated and measured specific gage relationships for Simmesport. Daily discharges and stages at Simmesport are available from River Gages, where the stages are measured and the discharges are computed using a stage-discharge rating curve. Some discharge measurements are available from USGS, which are also shown in the figure. The calculated and measured specific gage plot for Melville, shown in Figure 48, uses the Simmesport discharge and the stage at Melville. Measured stage at Melville is available from River Gages. The River Gages symbols in Figure 48 use discharges from the Simmesport River Gages data for the same date. USGS discharge measurements are also shown in the figure. 
Figure 47. Calculated and measured specific gage at Simmesport (RM -4.34).

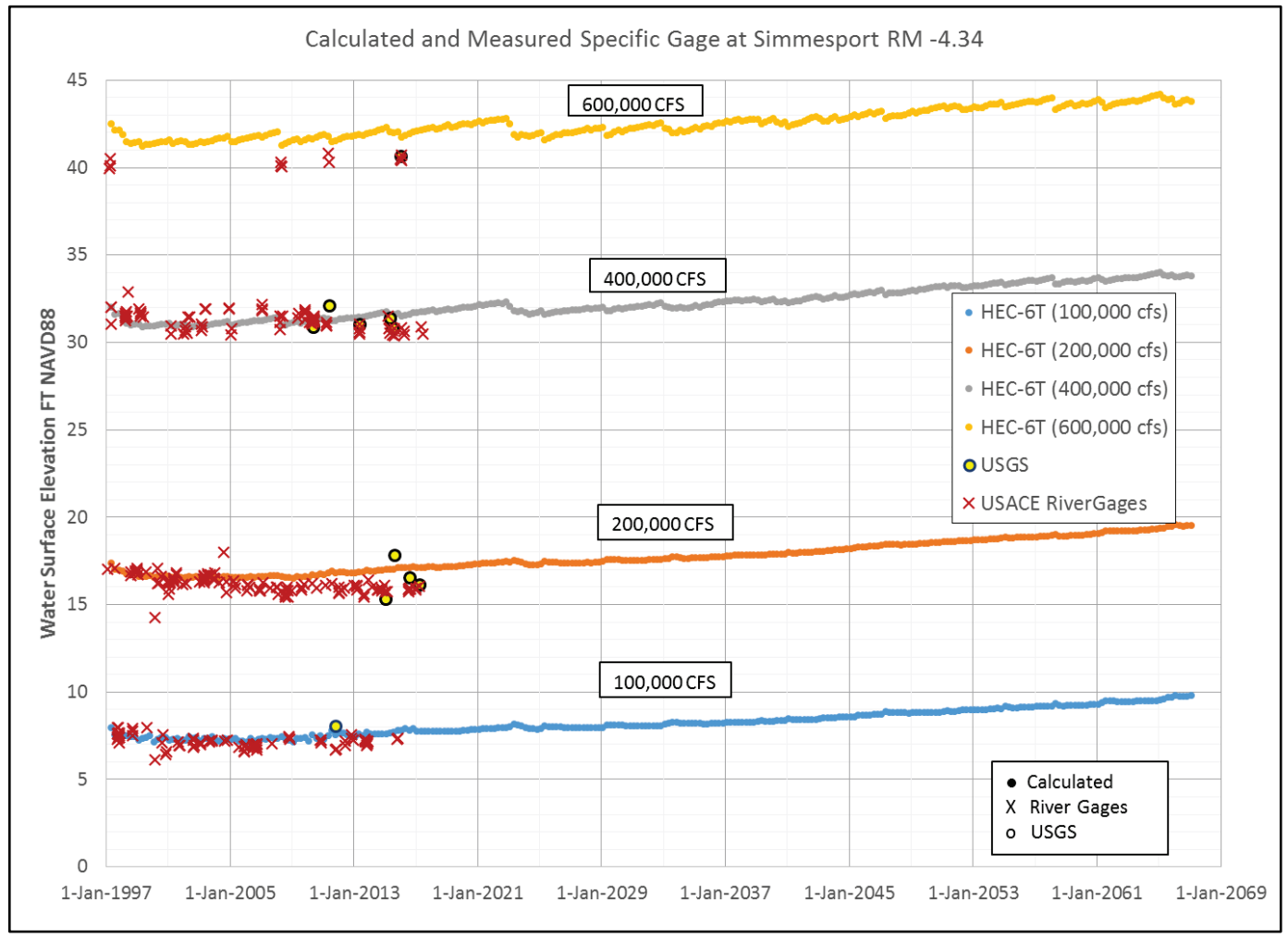

Figure 48. Calculated and measured specific gage at Melville (RM -29.6).

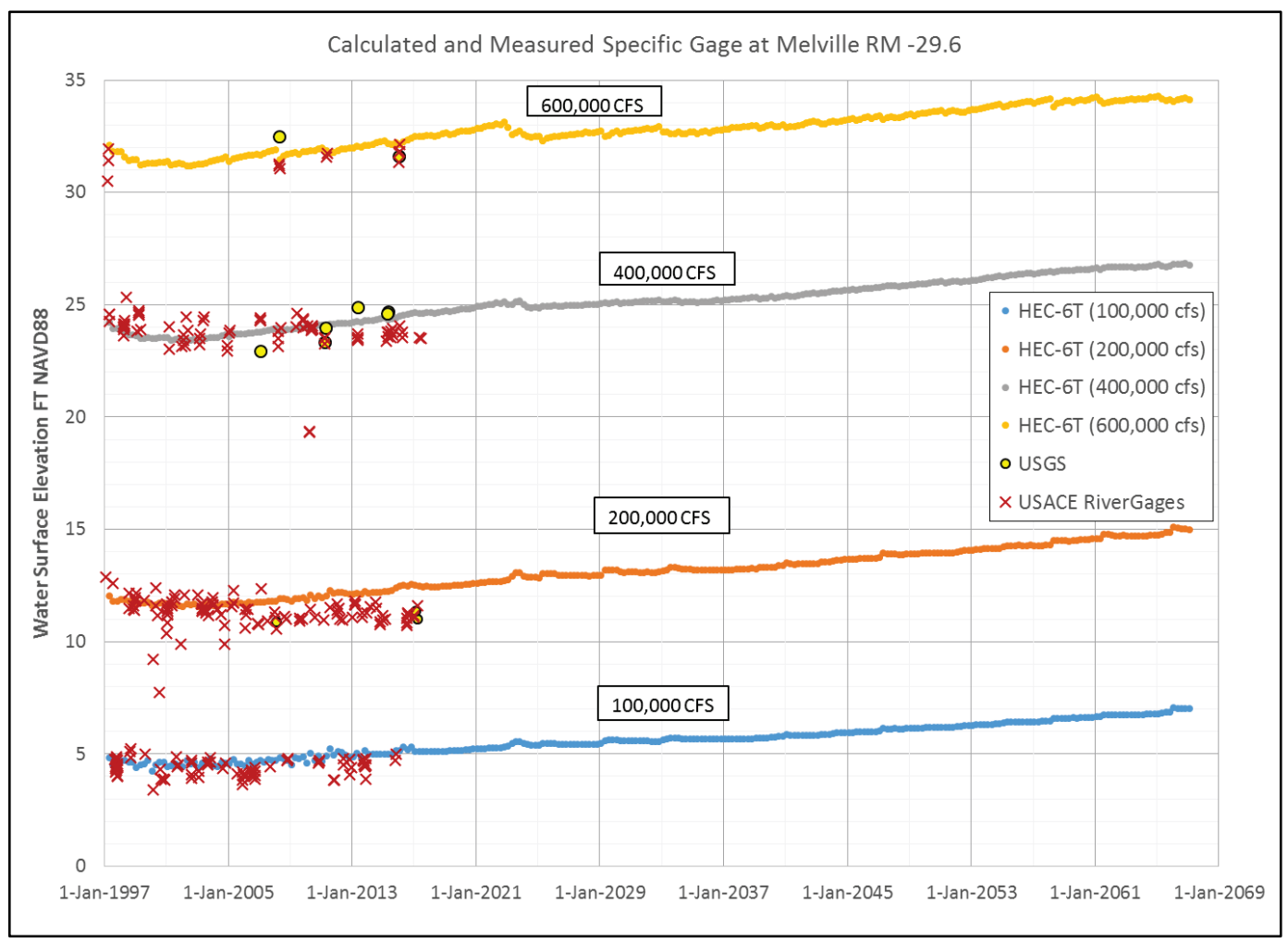


Figure 49 and Figure 50 show the measured and calculated specific gage relationships for Calumet and Morgan City, respectively. The measured USGS data come from measured stage and computed discharge for the Calumet and Morgan City figures. The large scatter in both the measured and calculated data at low flows is caused by a large tidal influence at low flows for Calumet and Morgan City. The clear influence of the Gulf of Mexico water level indicates that these two gages will be influenced by sea level rise, especially at low discharges. Indeed, both gages show a specific gage trend going upward for low discharges of 50,000 $\mathrm{cfs}$ and 100,000 cfs. In addition to sea level rise, the Morgan City stage trend for all discharge relationships is upward due to deposition in the channel. Calumet specific gage trends are slightly upward for the lower discharges of 50,000 cfs and $100,000 \mathrm{cfs}$, but the stages trend downward for the 300,000 cfs discharge due to limited scour in the Wax Lake Outlet.

Figure 49. Calculated and measured specific gage at Calumet (RM -111.2).

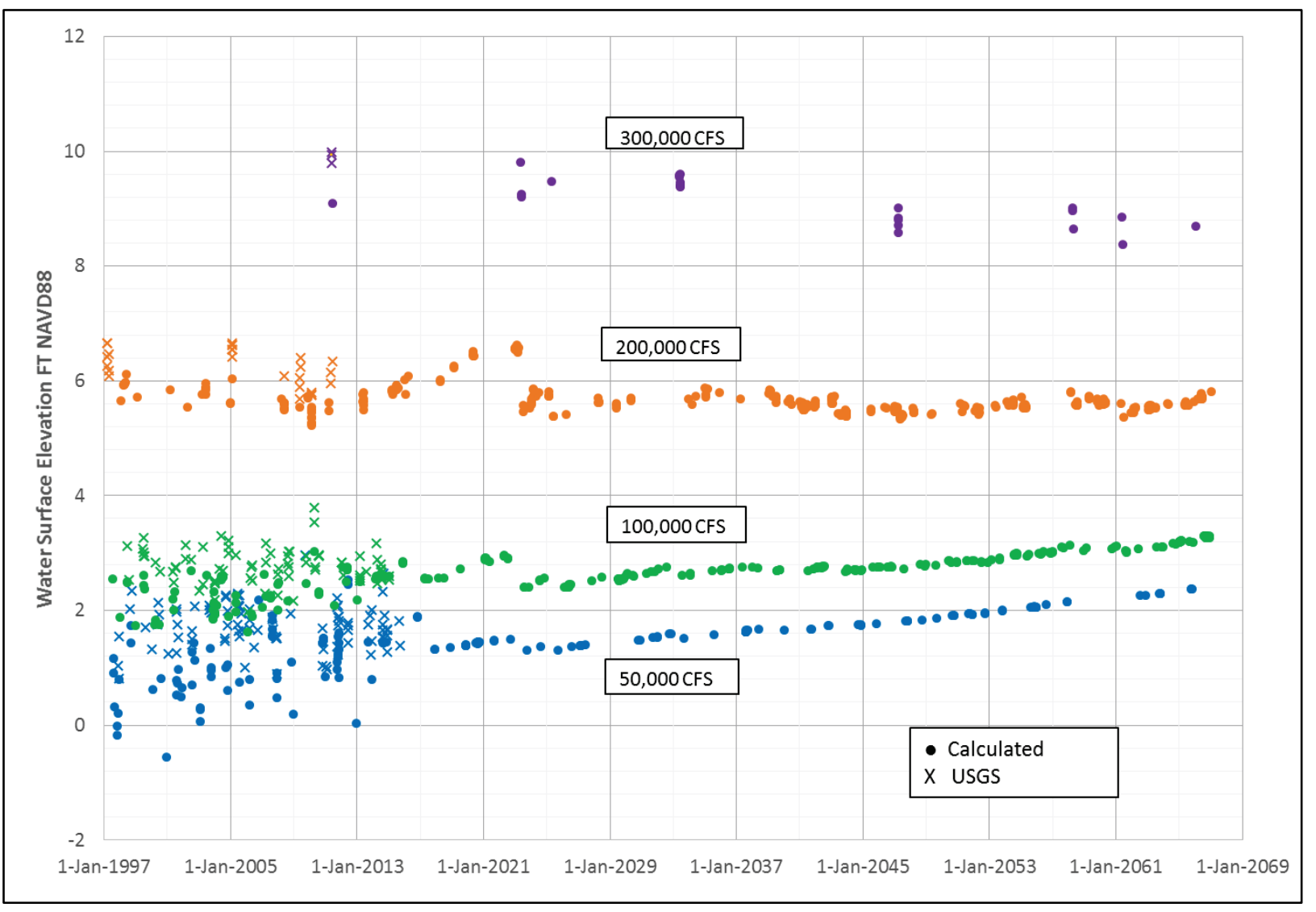


Figure 50. Calculated and measured specific gage at Morgan City (RM -121.2).

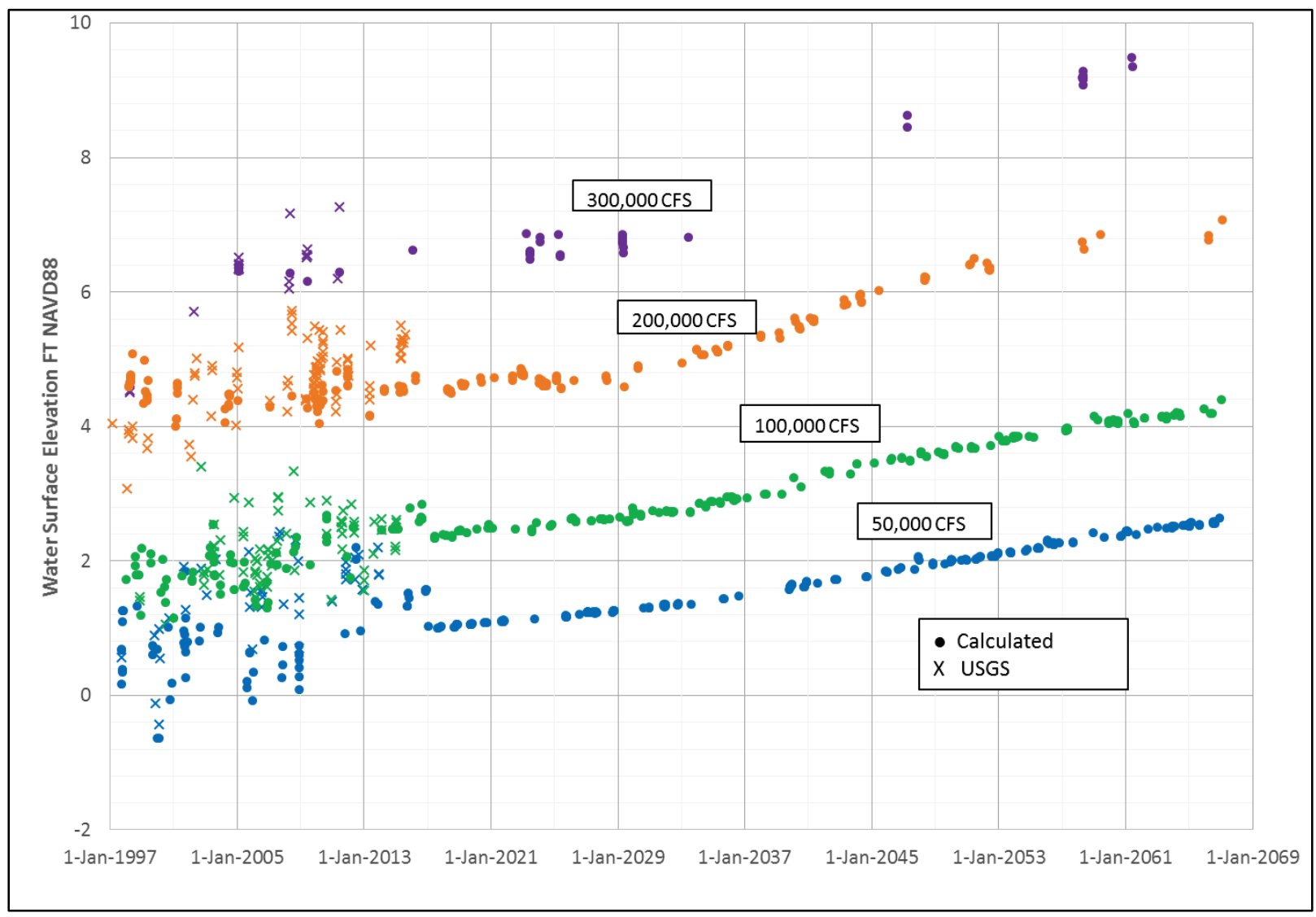

\subsubsection{Effect of subsidence}

The effect of subsidence was calculated by running the model with and without subsidence turned on. Figure 51 shows the water surface elevations of the PDF event hydrograph peak, beginning with 2066 conditions. Subsidence is estimated to lower the peak PDF water surface elevations by as much as $0.65 \mathrm{ft}$. The difference is zero at the downstream end because the Gulf of Mexico tailwater boundary condition is the same for both simulations, and that is the primary driver of the water surface at the downstream end. 
Figure 51. Water surface elevations for the PDF in 2066 with and without subsidence (only segments 1, 3, 4, and 6 are shown for clarity).

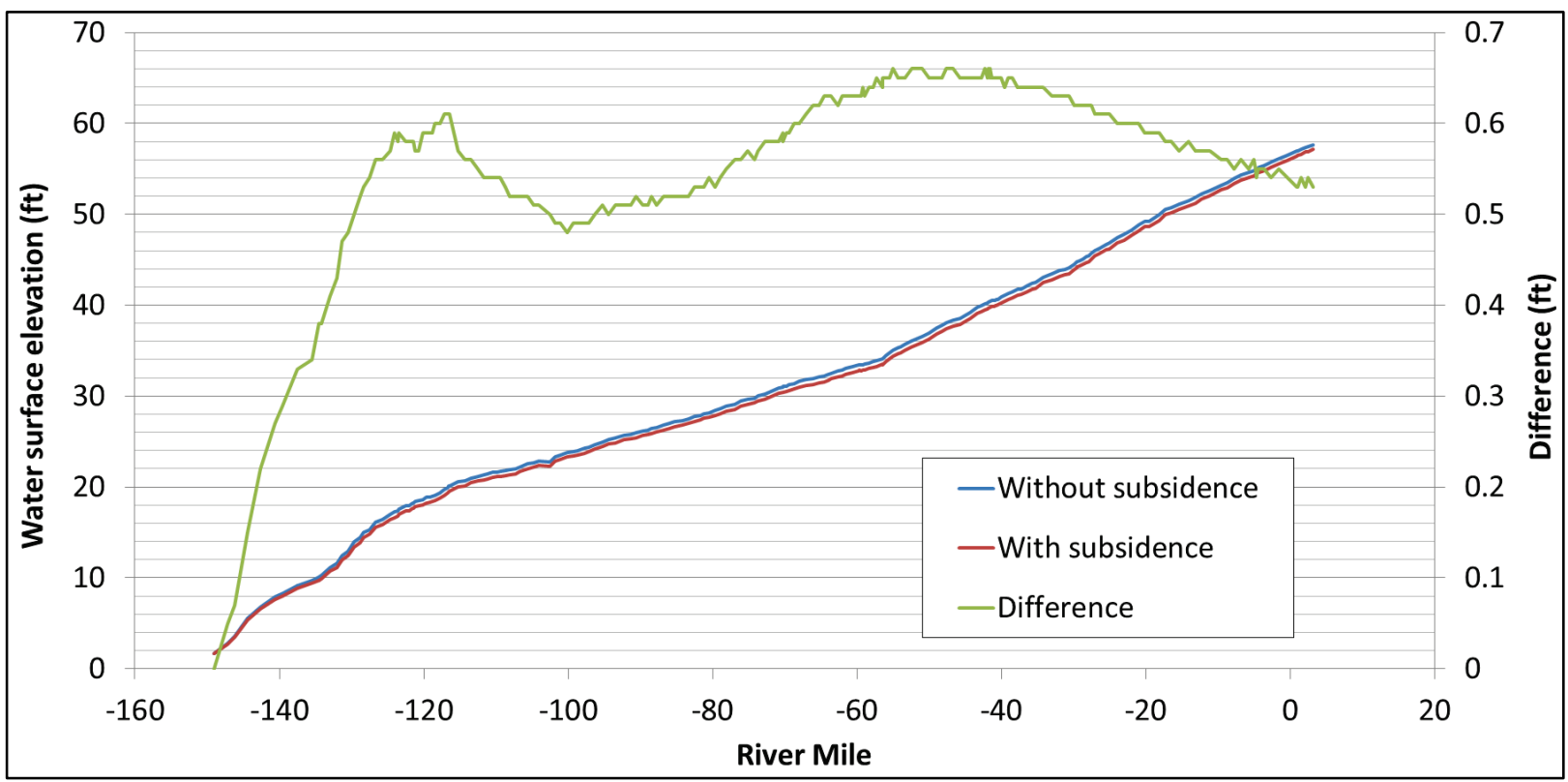

\subsubsection{Effect of sea level rise}

The three different sea level rise curves recommended in ER 1100-2-8162 (USACE 2013) were simulated within the HEC-6T model to show the sensitivity to sea level rise. Figure 52 shows the water surface elevations of the PDF event hydrograph peak, beginning with 2066 conditions, for each of the sea level rise curve scenarios. As expected, sea level rise has a greater influence at the downstream end and decreases in the upstream direction. 
Figure 52. Water surface elevations for the PDF in 2066 with the three SLR curves (only segments 1, 3, 4, and 6 are shown for clarity).

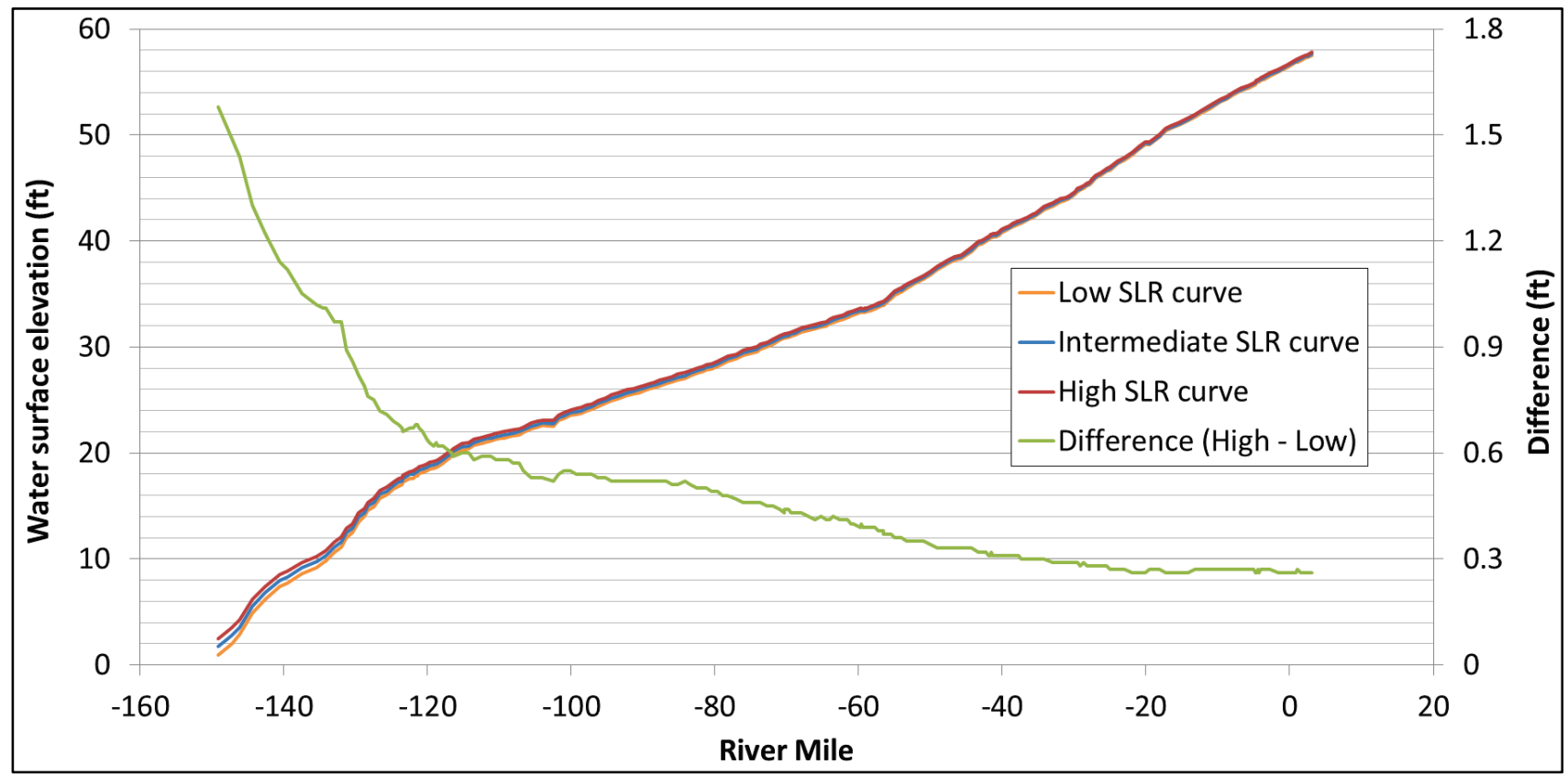

\subsubsection{Effect of sediment inflow}

The sediment inflow boundary condition is an important factor in predicting the Atchafalaya River sedimentation. The sediment inflow curve used in the calibration and verification study was based on 19952013 data from Simmesport. Sediment concentration data at Melville has a slightly longer record into recent years, extending into 2017. Figure 53 shows the Melville sand concentrations in two data sets: 1995 to 2017 and 2008 to 2017. The sand concentrations since 2008 are slightly lower than the 1995 to 2017 time period, especially at higher discharges. To quantify the impact of this type of change, the sediment inflow concentrations were adjusted lower in the HEC-6T model in year 2008 according to the differences in the Melville sand concentration data. The approximate decline in sand concentration is approximately $3 \%$ at 100,000 cfs, approximately $15 \%$ at $200,000 \mathrm{cfs}$, and approximately $25 \%$ for discharges equal to or greater than 400,000 cfs. Figure 54 shows the difference between the specific gage stages using the sediment inflow adjustment in 2008 at Simmesport. By 2066, the 2008 sediment inflow reduction results in approximately $3 \mathrm{ft}$ lower stages at high discharges. The difference is smaller for lower discharges, less than $2 \mathrm{ft}$ for $100,000 \mathrm{cfs}$. This figure suggests that the adjusted sediment inflow curve is producing a better result in terms of matching specific gage data during the historical period. 
Figure 53. Sand concentration at Melville, 1995 to 2017.

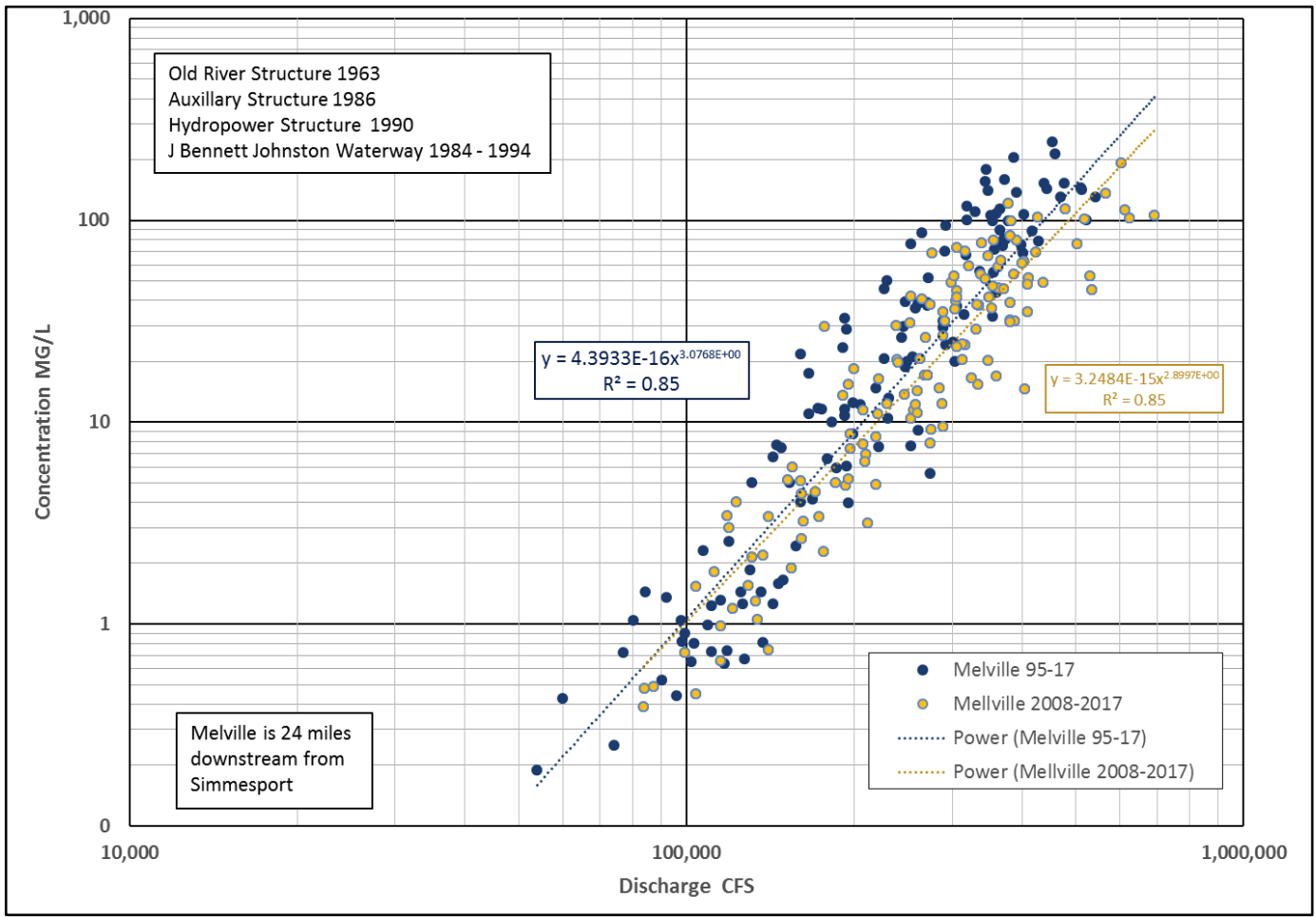

Figure 54. Impact of a sediment inflow adjustment in specific gage at Simmesport.

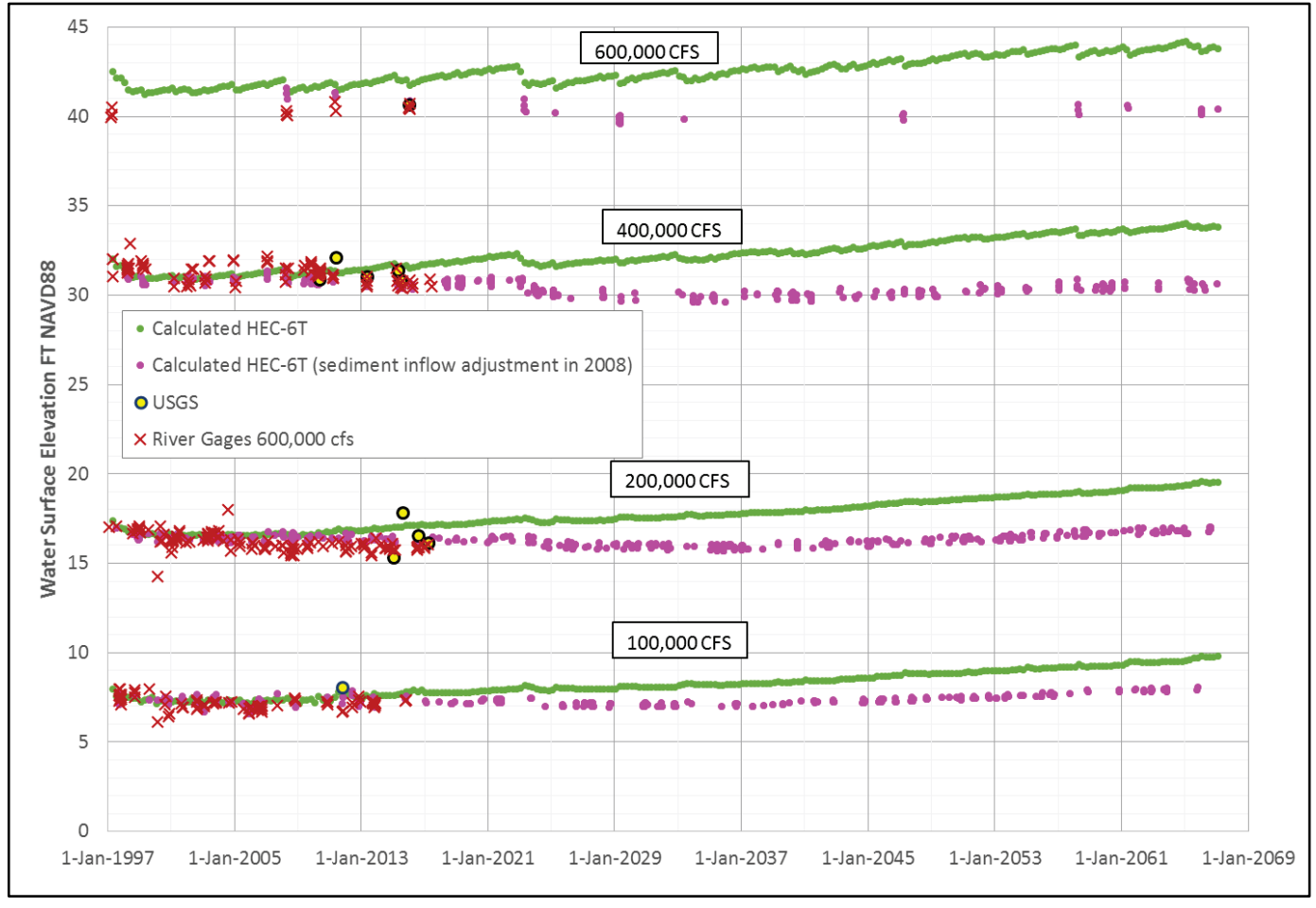




\subsubsection{Effect of Wax Lake Outlet sediment diversion coefficient}

The sensitivity of the results to the Wax Lake Outlet sediment diversion coefficient was calculated by adjusting the sediment diversion coefficient $+/-10 \%$. The proportion of coarse sediment $(>0.0625 \mathrm{~mm}$ ) concentrations, relative to the concentration immediately upstream of the bifurcation, was initially simulated with a diversion coefficient of 1.o. Here, the diversion coefficient for coarse sediment is adjusted to values of 0.9 and 1.1 to evaluate changes in the results. Figure 55 through Figure 58 show the effect of the sediment diversion coefficient on sand concentrations and total sediment concentrations at both Calumet and Morgan City. A trend in differences can be seen at Calumet, with an increasing diversion coefficient leading to higher concentrations at Calumet. No such trend exists for Morgan City, which demonstrates that the Morgan City concentrations are not sensitive to the diversion coefficient. Figure 59 shows that bed elevations of a cross section near the upstream end of Segment 1 (station -104.0) are sensitive to the sediment diversion coefficient. For this location, decreasing the sediment diversion coefficient leads to deposition.

Figure 55. Effects of sediment diversion coefficient on sand concentrations at Calumet (SD: sediment diversion coefficient into the Wax Lake Outlet).

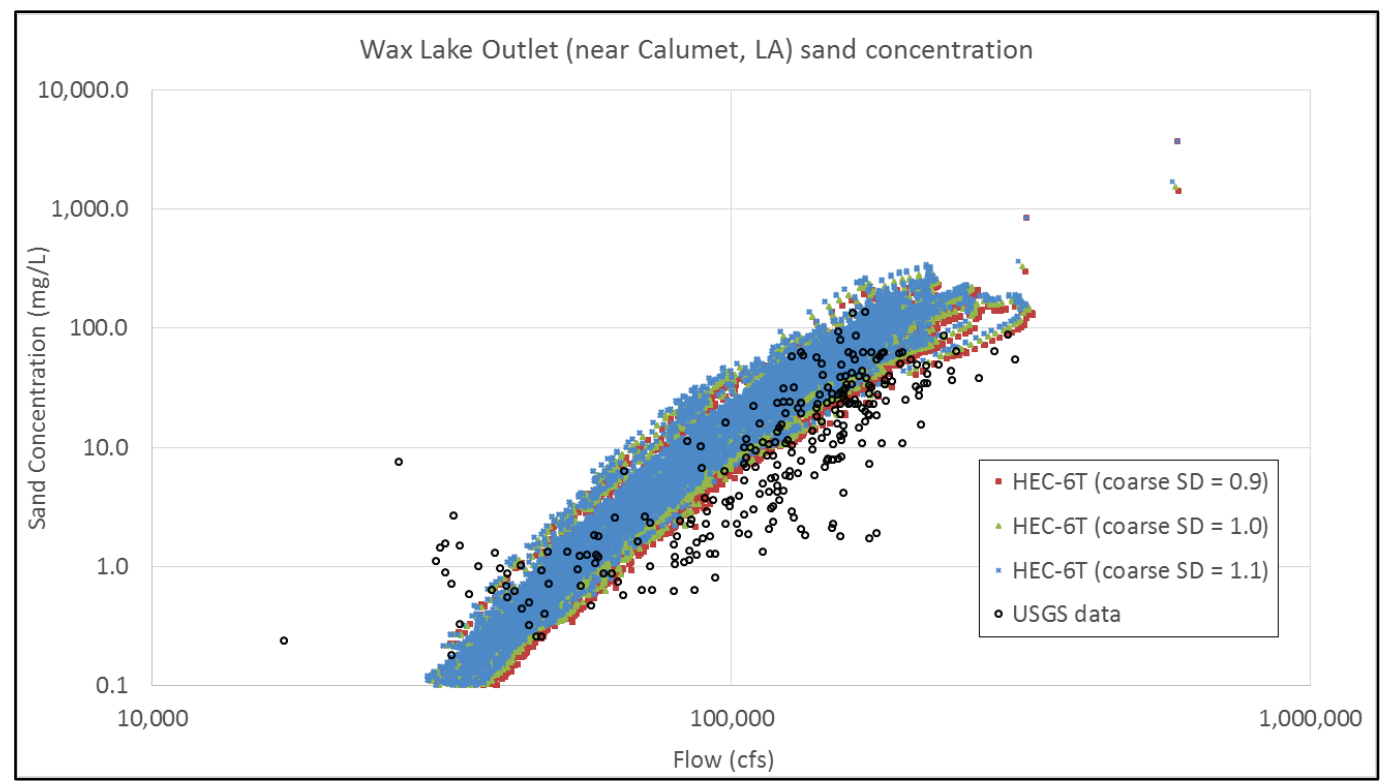


Figure 56. Effects of sediment diversion coefficient on total sediment concentrations at Calumet (SD: sediment diversion coefficient into the Wax Lake Outlet).

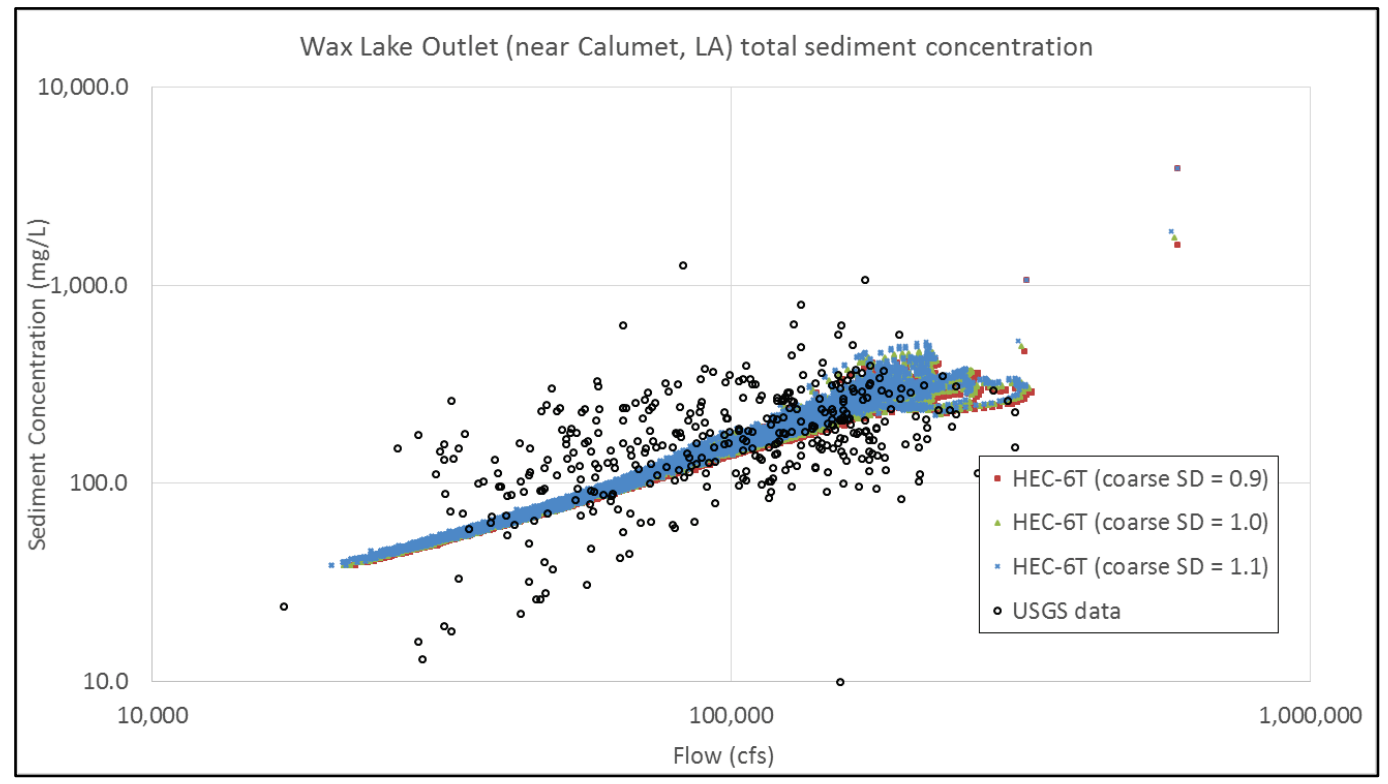

Figure 57. Effects of sediment diversion coefficient on sand concentrations at Morgan City (SD: sediment diversion coefficient into the Wax Lake Outlet).

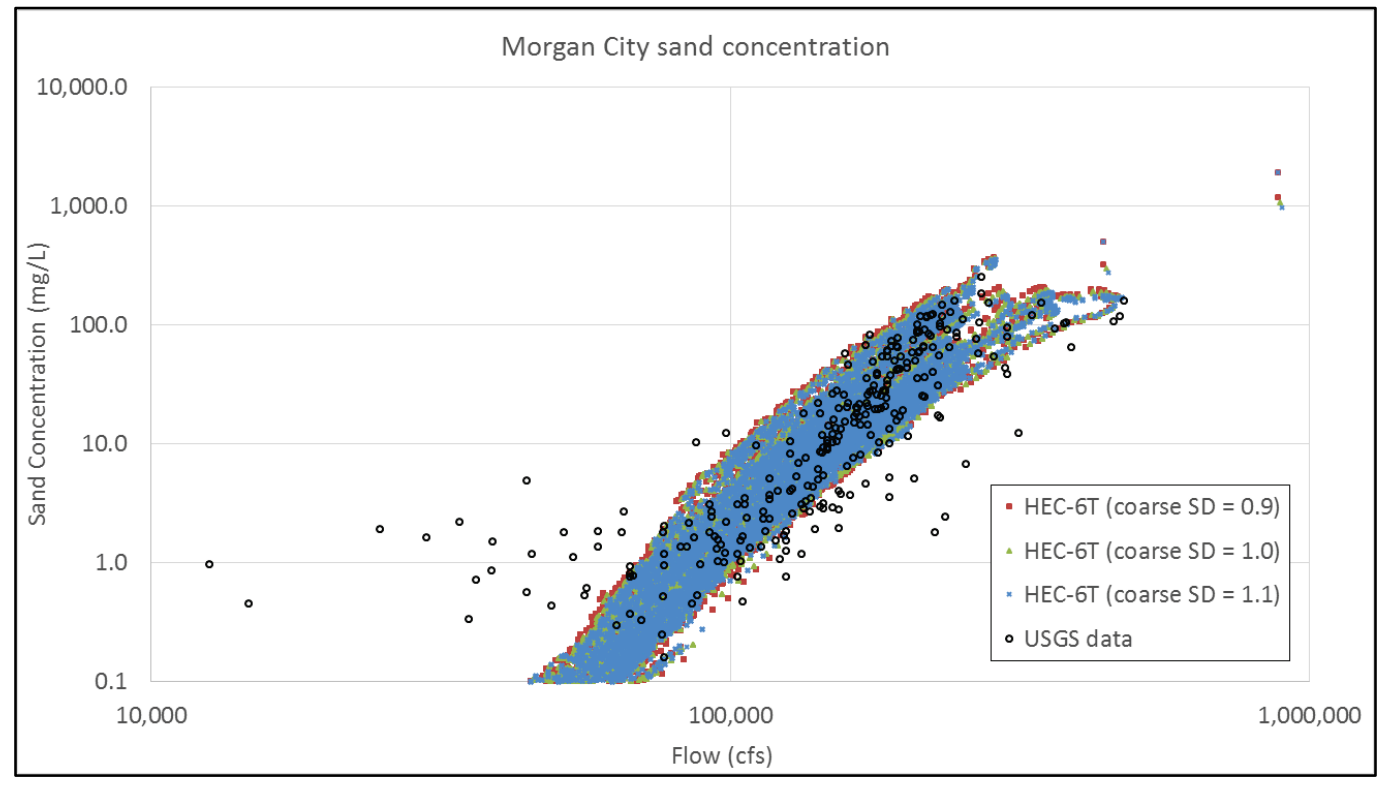


Figure 58. Effects of sediment diversion coefficient on total sediment concentrations at Morgan City (SD: sediment diversion coefficient into the Wax Lake Outlet).

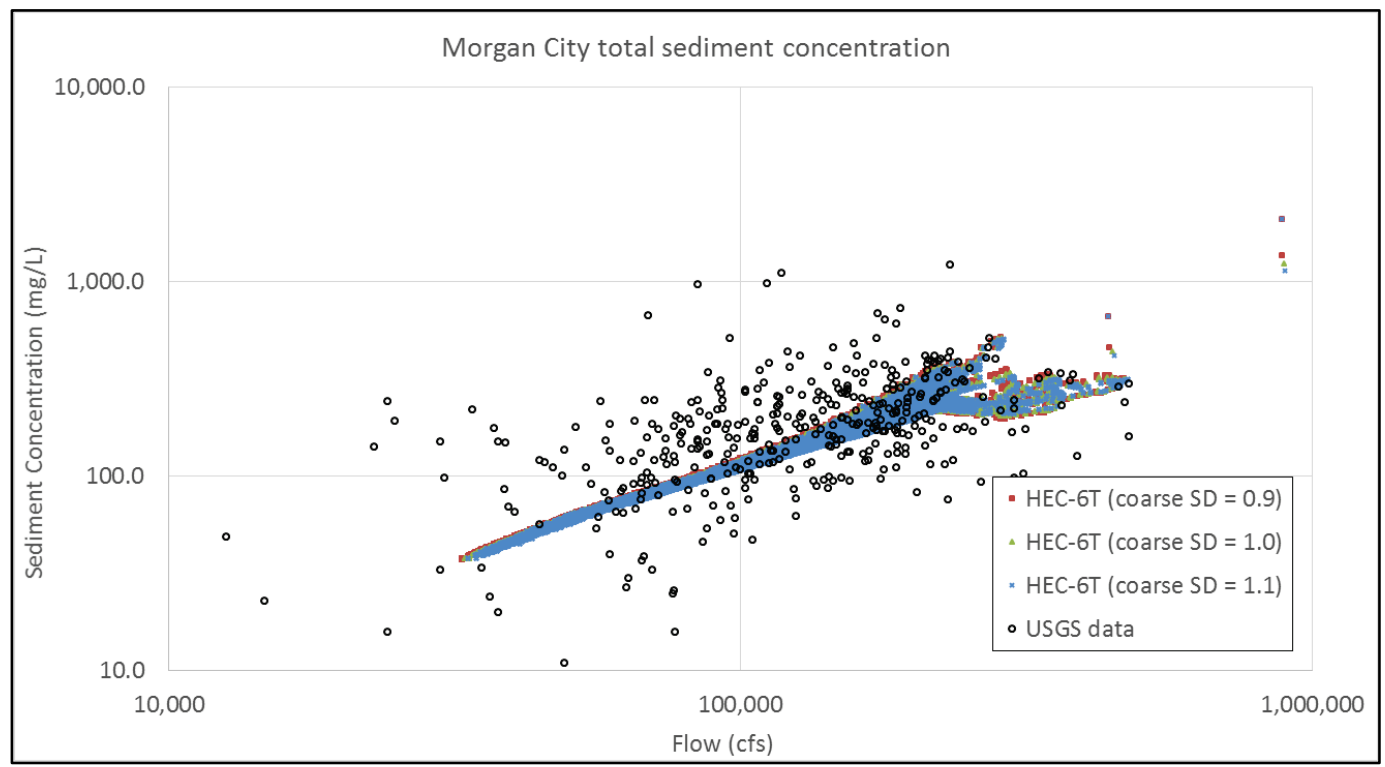

Figure 59. Effects of sediment diversion coefficient on bed elevations for cross section -104.0 in Segment 1.

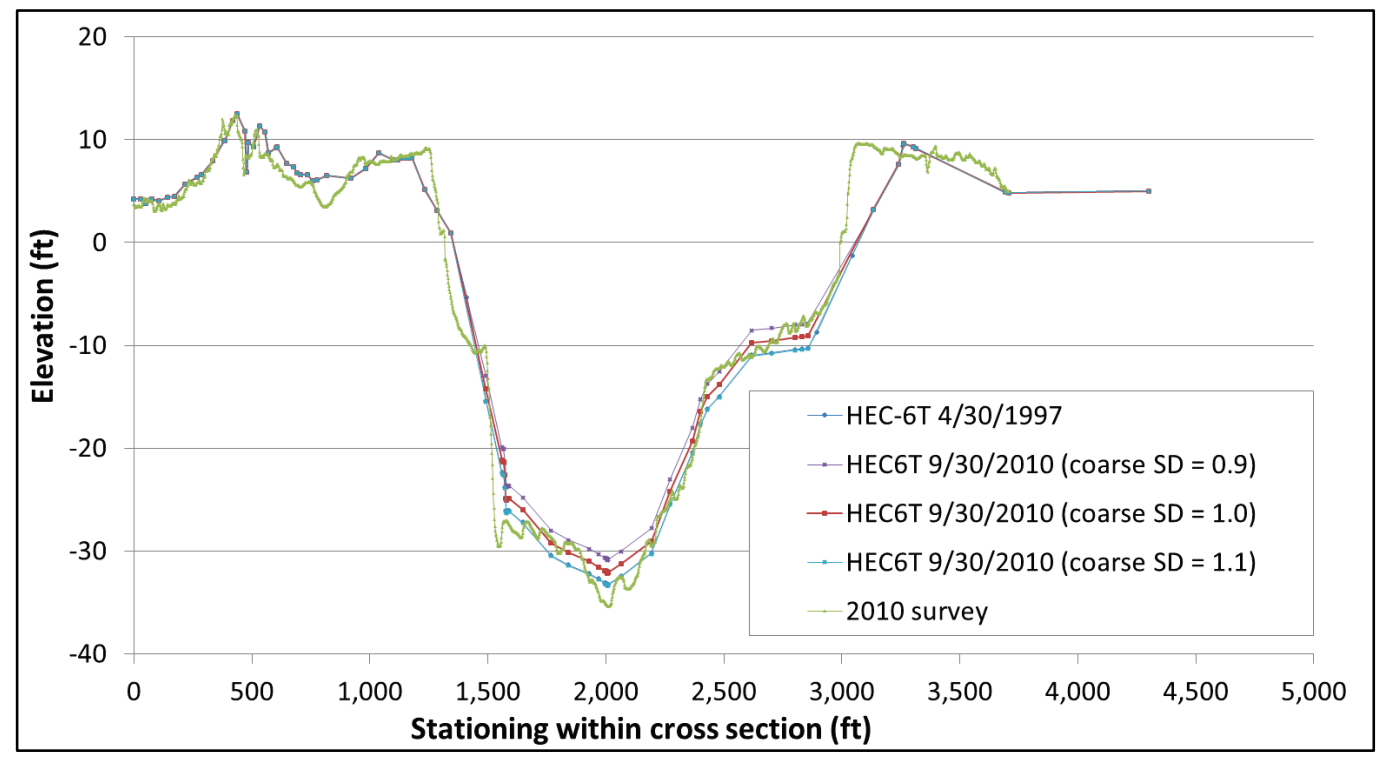

\subsubsection{Effect of water temperature}

The effect of water temperature on the sediment transport was evaluated by comparing a simulation of constant temperature with a simulation using monthly average temperatures. The constant water temperature simulation was set to a value of $66^{\circ} \mathrm{F}$, which is representative of the mean of the monthly water temperature shown in Figure 3. Figure 60 shows the water surface elevations of the PDF event hydrograph peak, beginning 
with 2066 conditions for the two different temperature scenarios. Using a constant water temperature causes a higher PDF water surface than the monthly water temperature simulation by up to $0.89 \mathrm{ft}$. The difference is zero at the downstream end because the Gulf of Mexico tailwater boundary condition is the same for both simulations, and that is the primary driver of the water surface at the downstream end.

Figure 60. Water surface elevations for the PDF in 2066 with constant water temperature and with monthly average water temperature (only segments $1,3,4$, and 6 are shown for clarity).

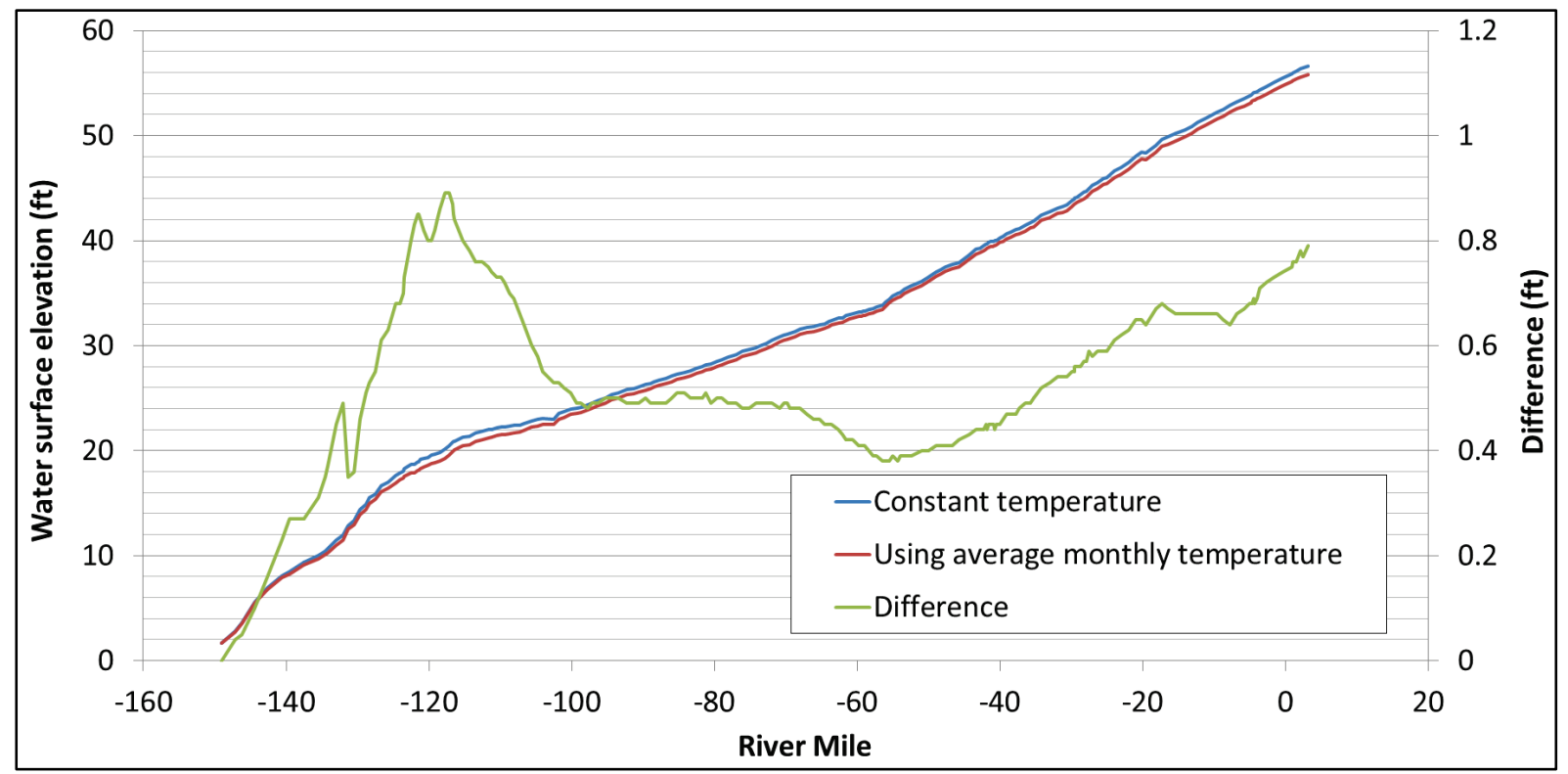




\section{Summary}

\subsection{Conclusions}

The HEC-6T sediment model of the Atchafalaya River simulated historical conditions from 1997 through 2016 and hypothetical conditions from 2017 through 2066. Changes were made to the 2010 HEC-6T model to calibrate and validate the model to the time period 1997 to 2016. The following major conclusions were made from the results of the HEC-6T model.

The Wax Lake Outlet is capturing an increasing amount of flow from the Lower Atchafalaya River.

The Project Design Flood (PDF) event scours the bed elevations by a large amount during the rising limb of the hydrograph, especially near Morgan City. This scour decreases the PDF water surfaces by as much as $5 \mathrm{ft}$.

Although the Upper Atchafalaya River has exhibited large amounts of scour in recent decades through New Orleans District (MVN) surveys, the sediment model projects a dynamic equilibrium to slightly increasing trend in water surfaces going forward. Future water surfaces in the upper reach could be lower than model projections due to channel widening, a process which should be included in future sediment modeling efforts of the Atchafalaya River.

Over the next 50 years, the sediment model results project trends of aggradation, or higher water surfaces into the future, for the Lower Atchafalaya River. Water surfaces during a PDF event occurring in 2067 will be up to $3 \mathrm{ft}$ higher than a PDF event occurring in 2011.

\subsection{Connection to hydraulic modeling}

The objective of the sediment study was to provide changes in channel bed elevations, due to sedimentation, for the fixed-bed HEC-RAS hydraulic model. These bed changes were applied to the HEC-RAS model and used to simulate future water surfaces. The HEC-RAS cross sections were not in the same locations as the HEC-6T cross sections, so the bed changes were averaged by reaches. Reaches varied in lengths and were determined by grouping together adjacent cross sections that exhibited similar bed changes. The HEC-6T software calculates average 
bed change between the channel stations; these results were output from the model for 30 Sep 2010; 30 Sep 2066; and at the peak of the $\mathrm{PDF}$ in 2067. Table 7 lists the average bed changes, by reach, that were reported for implementation into the HEC-RAS model. Both the longterm bed change, from 2010 to 2066, and the bed change during the PDF event (scenario 58A-R Authorized Yazoo) are reported.

To determine maximum PDF water-surface elevations for existing (2010) conditions, channel bed elevations in the HEC-RAS model should be adjusted using the values from the column labeled "Bed change (ft) within the PDF event" in Table 7. To determine maximum PDF water surface elevations for future (2066) conditions, channel bed elevations in the HEC-RAS model should be adjusted using the sum of the values in the last two columns of Table 7 .

Table 7. Average bed change results by reach.

\begin{tabular}{|c|c|c|c|c|c|c|}
\hline $\begin{array}{c}\text { Upstream } \\
\text { HEC-6T } \\
\text { Cross } \\
\text { Section }\end{array}$ & $\begin{array}{c}\text { Downstream } \\
\text { HEC-6T } \\
\text { Cross } \\
\text { Section }\end{array}$ & $\begin{array}{c}\text { HEC-RAS } \\
\text { River }\end{array}$ & $\begin{array}{c}\text { Upstream } \\
\text { HEC-RAS } \\
\text { Cross Section }\end{array}$ & $\begin{array}{c}\text { Downstream } \\
\text { HEC-RAS } \\
\text { Cross Section }\end{array}$ & $\begin{array}{c}\text { Bed Change } \\
\text { (ft) from } \\
10 / 1 / 2010 \\
\text { to } \\
9 / 30 / 2066\end{array}$ & $\begin{array}{c}\text { Bed } \\
\text { Change } \\
\text { (ft) within } \\
\text { the PDF } \\
\text { Event }\end{array}$ \\
\hline-146.2 & -149.1 & Atch & 18957.01 & 2719.914 & 1 & -4 \\
\hline-144.4 & -144.4 & Atch & 25881.71 & 25881.71 & $2.7 *$ & 0 \\
\hline-140.6 & -142.6 & Atch & 41382.14 & 33563.18 & 2.8 & 0 \\
\hline-137.5 & -139.5 & Atch & 57287.42 & 47666.67 & 2.8 & -4.5 \\
\hline-135.5 & -135.5 & Atch & 63075.32 & 63075.32 & $8.2 *$ & -4.5 \\
\hline-129.6 & -134.5 & Atch & 94485.92 & 68558.72 & 4.8 & -4.5 \\
\hline-124.7 & -128.8 & Atch & 120513.6 & 98835.9 & 5 & -12.5 \\
\hline-123.6 & -124 & Atch & 125947 & 123105.8 & 5 & -25.5 \\
\hline-122 & -123.4 & Atch & 134315.2 & 128249.9 & 5.7 & -25.5 \\
\hline-120.1 & -121.6 & Atch & 143623.7 & 135620.3 & 0 & -9 \\
\hline-117.2 & -119.7 & Atch & 156948.7 & 146057.3 & 6 & -16.5 \\
\hline-116.4 & -116.7 & Atch & 162338.7 & 159741.5 & 6 & -0.5 \\
\hline-104 & -115.2 & Atch & 227227.7 & 165558.3 & 10.5 & -0.5 \\
\hline-125 & -125 & WaxLake & 32561.78 & 26764.01 & 0.5 & -6.5 \\
\hline-123.3 & -123.3 & WaxLake & 38069.36 & 38069.36 & -5.3 & -2.5 \\
\hline-120.8 & -122.7 & WaxLake & 48692.56 & 41565 & -5.3 & -1 \\
\hline-115.2 & -119.8 & WaxLake & 79657 & 56100.93 & -5.3 & 0 \\
\hline-111.7 & -114.9 & WaxLake & 97192.81 & 81922.72 & 0 & 0 \\
\hline-111.2 & -111.2 & WaxLake & 99864.52 & 99864.52 & -4 & 0 \\
\hline-109.3 & -110.5 & WaxLake & 112305.5 & 104402.8 & -10 & 0 \\
\hline-102 & -108.3 & WaxLake & 155746 & 113545.4 & -0.7 & 0 \\
\hline-101.1 & -102.5 & Atch & 243947.4 & 230375.6 & 8.2 & 0 \\
\hline
\end{tabular}




\begin{tabular}{|c|c|c|c|c|c|c|}
\hline $\begin{array}{c}\text { Upstream } \\
\text { HEC-6T } \\
\text { Cross } \\
\text { Section }\end{array}$ & $\begin{array}{c}\text { Downstream } \\
\text { HEC-6T } \\
\text { Cross } \\
\text { Section }\end{array}$ & $\begin{array}{c}\text { HEC-RAS } \\
\text { River }\end{array}$ & $\begin{array}{c}\text { Upstream } \\
\text { HEC-RAS } \\
\text { Cross Section }\end{array}$ & $\begin{array}{c}\text { Downstream } \\
\text { HEC-RAS } \\
\text { Cross Section }\end{array}$ & $\begin{array}{c}\text { Change } \\
\text { (ft) from } \\
\text { 10/2010 } \\
\text { to } \\
9 / 30 / 2066\end{array}$ & $\begin{array}{c}\text { Bed } \\
\text { Change } \\
\text { (ft) within } \\
\text { the PDF } \\
\text { Event }\end{array}$ \\
\hline-88.5 & -100.1 & Atch & 306553.2 & 246498.7 & 6.8 & 0 \\
\hline-70.3 & -87.7 & Atch & 398154.3 & 310726.6 & 4 & 0 \\
\hline-70.3 & -75.1 & AtchSplit & 28319.64 & 2874.749 & 4 & 0 \\
\hline-56.5 & -70.31 & Atch & 470193.8 & 400592.8 & 4 & 4 \\
\hline-55.4 & -78.8 & AtchSplit & 125437.1 & 33140.38 & 2 & 0 \\
\hline 10.12 & -56.5 & Atch & 751747.4 & 475518.4 & 3.5 & -1.5 \\
\hline
\end{tabular}

Note: * indicates the bed change should only apply to the non-dredged part of the channel.

The error associated with accounting for sedimentation effects by using average reach adjustments to the bed elevations in the numerical model was estimated. The base condition was defined using calculated water surface elevations from the HEC-6T numerical model from the 30 Apr 1997 to Sep. 30, 2066 simulation followed by the PDF hydrograph. An instantaneous PDF peak discharge was inserted into the base simulation on 30 Sep 2010, 30 Sep 2066, and after the rise of the PDF hydrograph to maximum discharge. September 2010 conditions represent the best estimate for the date of the geometry used in the HEC-RAS model.

The reach-averaged bed elevation changes for the period between 30 Sep 2010 and 30 Sep 2066 (shown in Table 7) were determined using both the HEC-6T calculated thalweg and average bed changes at each cross section for the 56-year period. An adjusted HEC-6T input file was created by adding the reach-averaged bed elevation changes to the calculated 30 Sep 2010 channel bed elevations (the calculated bed elevations for Sep 2010 came from an HEC-6T output file). A PDF instantaneous peak discharge was then used with the adjusted geometry to calculate PDF peak water surface elevations. The water surface profile calculated with the adjusted geometry was compared to the water surface profile calculated using the actual geometry to estimate the error in this reach-averaged approach.

A comparison of PDF peak water surface elevation differences for the 56-year period is shown in Figure 61. Errors range between $+0.3 \mathrm{ft}$ and -0.6 ft. Downstream from Morgan City, the PDF water surface elevations calculated using the adjusted bed elevations from Table 4 in a fixed bed model would generally be too high. Upstream from Morgan City, the PDF water surface elevations calculated using the adjusted bed 
elevations from Table 7 in a fixed bed model would generally be too low. The most likely reason is related to the disproportionate deposition and/or scour on crossings and bends that occurs with the actual flood hydrograph.

A comparison of PDF peak water surface elevation differences when using the reach averaged adjusted cross sections to account for the rise of the PDF hydrograph is shown in Figure 62. Error associated with the calculated water surface elevations using the reach-averaged adjusted bed elevations to estimate the effects of sedimentation during the hydrograph rise was $+/-0.9 \mathrm{ft}$.

This approach using reach-averaged bed elevation adjustments seemed appropriate at the beginning of the study because there was an existing HEC-6T numerical model that was thought to require only minor adjustments for this study. A more rigorous approach would have been to use the same geometry used in the HEC-RAS model for the HEC-6T model even though this would have required a significant calibration and validation process. Calculated bed elevation changes could then be applied directly to each cross section and transferred to the HEC-RAS model without trying to determine reach-averaged approximations. That is the preferred approach for future work. 
Figure 61. Difference in calculated PDF peak water surface elevation after 56 years. (The difference is determined by subtracting the water surface elevation calculated using the actual geometry and the 2010-2066 hydrograph from the water surface elevation calculated using the "adjusted" channel bed geometry, where "adjusted" is based on Table 7.)

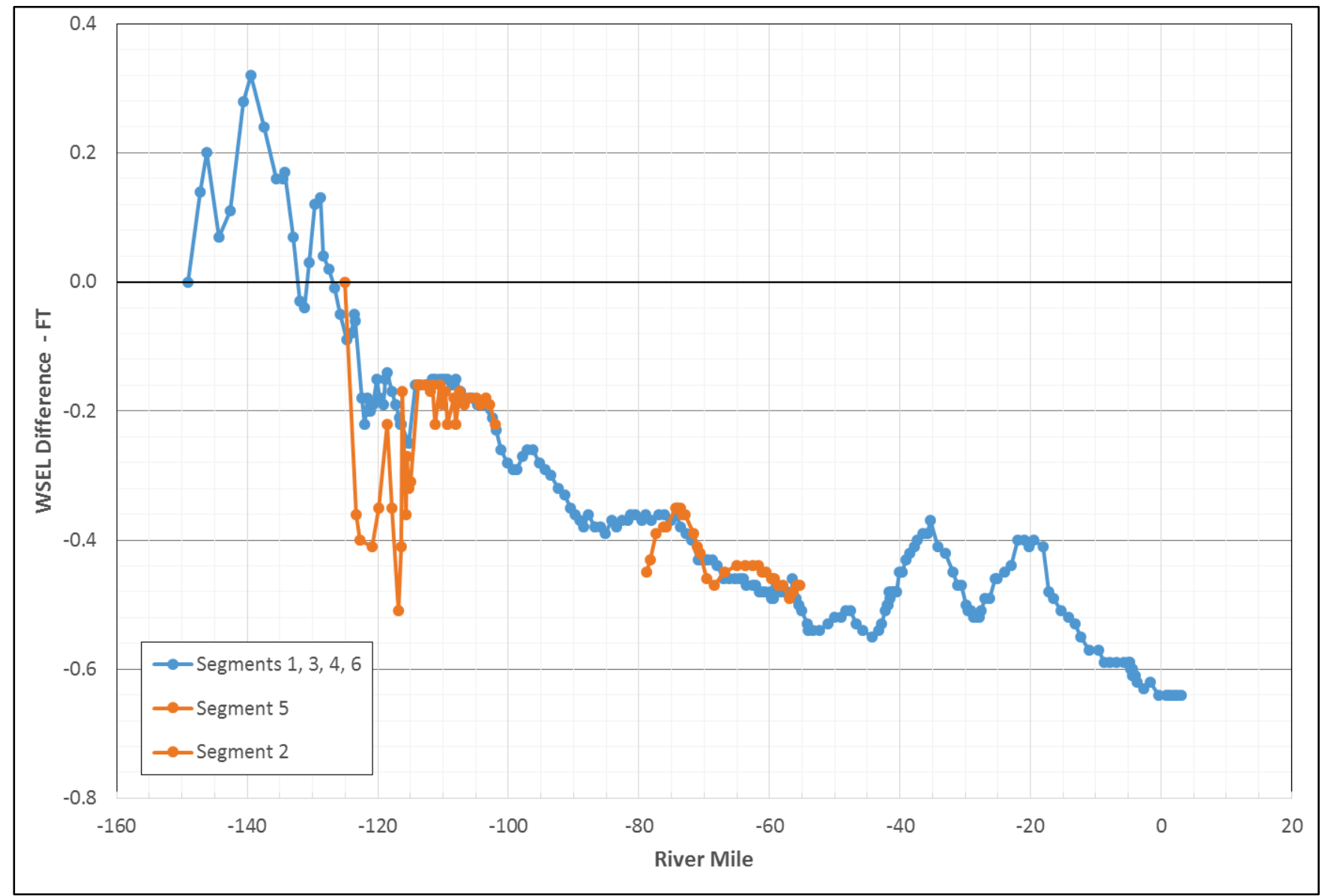


Figure 62. Difference in calculated PDF peak water surface elevation due to the rise of the PDF hydrograph. (The difference is determined by subtracting the water surface elevations calculated using the actual geometry and the PDF hydrograph from the water surface elevation calculated using the "adjusted" channel bed geometry and an instantaneous PDF peak discharge, where "adjusted" is based on Table 7.)

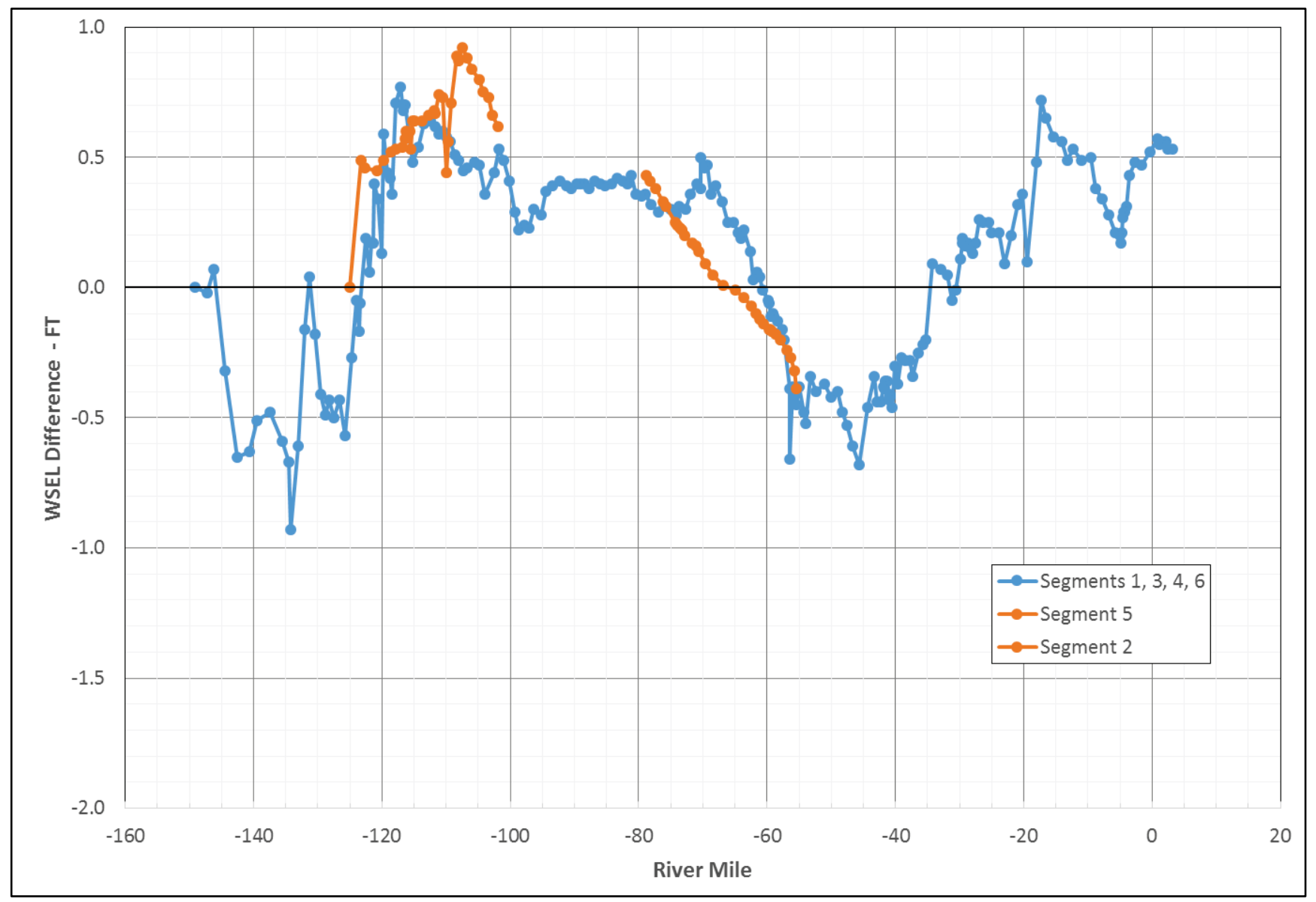




\section{References}

Bell, G., N. Clifton, and D. Abraham. 2017. Phase One - Hydrodynamics of the Morganza Floodway. MRG\&P Report No. 13. Vicksburg, MS: U.S. Army Engineer Research and Development Center.https://erdclibrary.erdc.dren.mil/xmlui/handle/11681/22823.

Ferguson, R. I. 1986. "River Loads Underestimated by Rating Curves." Water Resources Research 22(1): 74-76. http://onlinelibrary.wiley.com/doi/10.1029/WR022i001p00074/abstract.

Maynord, S. T. 2014. Scour Protection Downstream of Morganza Control Structure, Morganza, Louisiana. ERDC/CHL TR-14-1. Vicksburg, MS: U.S. Army Engineer Research and Development Center. https://erdc-

library.erdc.dren.mil/xmlui/handle/11681/7344

Mossa, J. 2016. "The Changing Geomorphology of the Atchafalaya River, Louisiana: A Historical Perspective." Geomorphology 252: 112-127. https://www.sciencedirect.com/science/article/pii/S0169555X15301318.

Nordin, C. F., and G. L. Posada. 1996. Changes in the Bed Sediment Size Distributions along the Atchafalaya River, 1932-1991: Major Factors and Consequences. Technical Paper. Ft. Collins, CO: Engineering Research Center, Colorado State University. https://www.sciencedirect.com/science/article/pii/S0169555X15301318.

Powell, N. 1996. "The Wax Lake Outlet Weir and Channel Response.” 6th FISC, Federal Interagency Sedimentation Conference, Las Vegas III. In Fluvial: Channel Evolution and Channel Stabilization 46-53.

Shaw, J. B., D. Mohrig, and S. K. Whitman. 2013. "The Morphology and Evolution of Channels on the Wax Lake Delta, Louisiana, USA.” Journal of Geophysical Research: Earth Surface 118: 1562-1584.

U.S. Army Corps of Engineers (USACE) MVK. 2005. Lower Atchafalaya River and Bayous Chene-Boeuf-Black Feasibility Study Sediment Analysis. Initiated by USACE MVN and completed by USACE MVK, Vicksburg, MS, November 2005.

USACE, Headquarters. 2013. Incorporating Sea Level Change in Civil Works Programs. ER 1100-2-8162. Washington, DC: U.S. Army Corps of Engineers. https://www.flseagrant.org/wp-content/uploads/USACE_SLR_guidance_ER_1100-2-8162.pdf. 


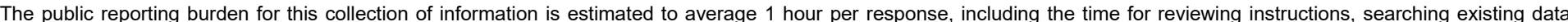

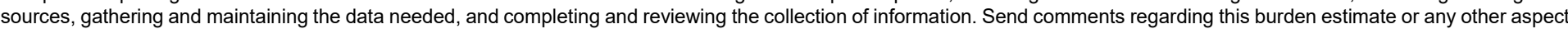

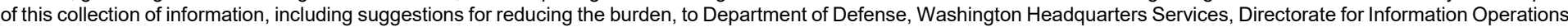

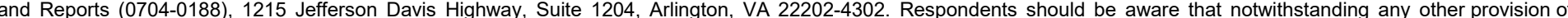
law, no person shall be subject to any penalty for failing to comply with a collection of information if it does not display a currently valid OMB control number.

PLEASE DO NOT RETURN YOUR FORM TO THE ABOVE ADDRESS.

\begin{tabular}{l|l|l} 
1. REPORT DATE & 2. REPORT TYPE & 3. DATES COVERED (From - To) \\
December 2018 & Report 5 of a series &
\end{tabular}

\section{TITLE AND SUBTITLE}

5a. CONTRACT NUMBER

Mississippi River and Tributaries Flowline Assessment: Atchafalaya River Sedimentation

Model Report

5b. GRANT NUMBER

5c. PROGRAM ELEMENT NUMBER

\section{AUTHOR(S)}

James W. Lewis and Ronald R. Copeland

5d. PROJECT NUMBER

449963

5e. TASK NUMBER

5f. WORK UNIT NUMBER

8. PERFORMING ORGANIZATION REPORT NUMBER

MRG\&P Report No. 24; Volume 5

10. SPONSOR/MONITOR'S ACRONYM(S)

USACE MVD

U.S. Army Corps of Engineers, Mississippi Valley Division

Mississippi River Geomorphology \& Potamology Program

1400 Walnut Street

Vicksburg, MS 39180

11. SPONSOR/MONITOR'S REPORT NUMBER(S)

12. DISTRIBUTION/AVAILABILITY STATEMENT

Approved for public release; distribution is unlimited.

13. SUPPLEMENTARY NOTES

\section{ABSTRACT}

A HEC-6T numerical sedimentation model study was conducted to determine the effects of long-term sedimentation processes on the Project Design Flood (PDF) flowline for the Atchafalaya River. The upstream extent of the model was the confluence of the Red River and the Old River Control Complex outflow channel, approximately 8.5 miles upstream of Simmesport, LA. There were two downstream ends of the model; each extended to the Gulf of Mexico, one for the Wax Lake Outlet and one for the Lower Atchafalaya River. The model was built from a previous study performed in 2010 using 1997 geometry. The calibration time period was 1997 to 2010 , and bed elevations were compared with a 2010 bathymetric survey. The model was validated by simulating the years 1997 through 2016 . Then the model simulated 50 years, from 2017 to 2066. Average bed changes were provided to the HEC-RAS model. The model incorporated the Morganza Control Structure flows, dredging, subsidence, and sea level rise. Model results showed that the Wax Lake Outlet is capturing an increasing amount of flow from the Lower Atchafalaya River, and the PDF scours the channel bed elevations during the rising limb of the hydrograph, especially near Morgan City.

\section{SUBJECT TERMS}

Atchafalaya River (La.) —Water levels, Flood control, Sedimentation and deposition-Computer simulation sediment transportComputer simulation River channels

16. SECURITY CLASSIFICATION OF:

\begin{tabular}{|l|c|l|}
\hline a. REPORT & b. ABSTRACT & c. THIS PAGE \\
Unclassified & Unclassified & Unclassified \\
\hline
\end{tabular}

17. LIMITATION OF ABSTRACT

SAR
18. NUMBER OF 19a. NAME OF RESPONSIBLE PERSON

PAGES James W. Lewis

98 19b. TELEPHONE NUMBER (Include area code) 601-634-3895 
7. PERFORMING ORGANIZATION NAME(S) AND ADDRESS(ES (continued)

Coastal and Hydraulics Laboratory

U.S. Army Engineer Research and Development Center

3909 Halls Ferry Road

Vicksburg, MS 39180-6199

U.S. Army Engineer Mississippi Valley Division

1400 Walnut St

PO Box 80

Vicksburg, MS 39180-0080 